\title{
UPDATE
}

NUCLEAR POWER PROGRAM

INFORMATION AND DATA

\section{OCTOBER - DECEMBER 1981}

\author{
PREPARED BY \\ OFFICE OF COORDINATION AND SPECIAL PROJECTS \\ OFFICE OF NUCLEAR REACTOR PROGRAMS \\ U.S. DEPARTMENT OF ENERGY
}




\section{DISCLAIMER}

This report was prepared as an account of work sponsored by an agency of the United States Government. Neither the United States Government nor any agency Thereof, nor any of their employees, makes any warranty, express or implied, or assumes any legal liability or responsibility for the accuracy, completeness, or usefulness of any information, apparatus, product, or process disclosed, or represents that its use would not infringe privately owned rights. Reference herein to any specific commercial product, process, or service by trade name, trademark, manufacturer, or otherwise does not necessarily constitute or imply its endorsement, recommendation, or favoring by the United States Government or any agency thereof. The views and opinions of authors expressed herein do not necessarily state or reflect those of the United States Government or any agency thereof. 


\section{DISCLAIMER}

Portions of this document may be illegible in electronic image products. Images are produced from the best available original document. 


\title{
DISCLAIMER
}

This report was prepared as an account of work sponsored by an agency of the United States Government. Neither the United States Government nor any agency thereof, nor any of their employees, makes any warranty, express or implied, or assumes any legal liability or responsibility for the accuracy, completeness, or usefulness of any information, apparatus, product, or process disclosed, or represents that its use would not infringe privately owned rights. Reference herein to any specific commercial product, process, or service by trade name, trademark, manufacturer, or otherwise does rot necessarily constitute or imply its endorsement, recommendation, or favoring by the United States Government or any agency thereof. The views and opinions of authors expressed herein do not necessarily state or reflect those of the United States Government or any agency thereof.

DOE/NBM--6011988

UPDATE

DE 86011988

\author{
NUClEAR POWER PROGRAM \\ INFORMATION AND DATA
}

OCTOBER - DECEMBER 1981

\section{PREPARED BY \\ OfFICE Of COORDINATION AND SPECIAL PROJECTS \\ OFFICE OF NUCLEAR REACTOR PROGRAMS \\ U.S. DEPARTMENT OF ENERGY}




\section{Preface}

UPDATE is published by the Office of Coordination and Special Projects, Office of Nuclear Reactor Programs, to provide a quick reference source on the current status of nuclear powerplant construction and operation in the United States and for information on the fuel cycle, economics, and performance of nuclear generating units. Similar information on other means of electric generation as related to nuclear power is included when appropriate.

The subject matter of the reports and analyses presented in UPDATE will vary from issue to issue, reflecting changes in foci of interest and new developments in the field of comercial nuclear power generation.

UPDATE is intended to provide a timely source of current statistics, results of analyses, and programmatic information proceeding from the activities of the Office of Nuclear Reactor Programs and other components of the Department of Energy, as well as condensations of topical articles from other sources of interest to the nuclear community. It also facilitates quick responses to requests for data and information of the type often solicited from this office.

We trust you find UPDATE interesting and helpfut.

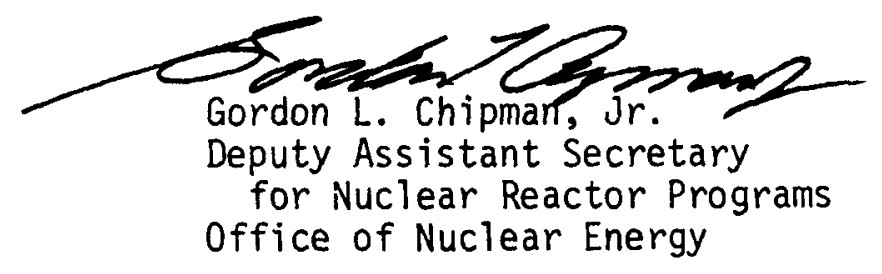




\section{Table of Contents}

Preface

I. Central Station Power Plants

A. Status of U.S. Nuclear Electric Generating I Capacity

B. Summary of Licensed Operating Reactors 4

C. Revitalizing Nuclear Power Plant Design and 7

Construction: Lessons Learned by TVA

D. NERC's Electric Power Projections for 1981-1990 18

E. Electrical World's Forecast of Peakload and 27 Capital Expenditures

II. Energy and Fue1s

A. U.S. Electric Utility Statistics 37

B. Spent Fuel and Radioactive Waste 40

C. NCA Revised Coal Forecast for $1981 \quad 46$

III. Economics

A. Analysis of Utility Reports on Nuclear Power Plant Capital Costs

B. Nuclear Versus Fossil Cost Post TMI

IV. Operation

A. NERC - Ten Year Review on Equipment Availability

and Component Cause Code Report

B. Update on TMI-2 Decontamination Process

C. Utility Briefs

1. Breeder Reactor Corporation, "Support for C1inch River"

2. Public Service Electric \& Gas Company, "Dedication of Salem Generating Station" 
C. Utility Briefs (Continued)

3. Vermont Yankee Nuclear Power Corporation, "Vernon Plant Refueling and Maintenance"

4. Public Service Indiana, "Nuclear Plant's Progress Gets a Lift"

5. Commonwealth Edison Company, "Switching to Nuclear"

V. Appendix

- Index to Articles Published in 1981 Issues 
I. CENTRAL STATION POWER PLANTS

A. Status of U.S. Nuclear Electric Generating Capacity

The status of central station nuclear electric generating units in the U.S. as of $12 / 31 / 81$ :

\begin{tabular}{cr} 
Number of & Capacity \\
Units & (MWe Net) \\
$12 / 31 / 81$ & $12 / 31 / 81$ \\
\hline
\end{tabular}

Operable

- Licensed by NRC $=\frac{1 /, 2 /}{2}$

- Authorized by DOE 3 /

Being Built

- Construction Permit Issued

- Limited Work Authorization Ordered

\begin{tabular}{rr}
75 & $57,578.0$ \\
2 & 910.0 \\
75 & $83,308.6$ \\
2 & $2,300.0$ \\
12 & $13,924.0$ \\
\hline 166 & $158,020.6$
\end{tabular}

1/ Includes the following units:

- Humboldt Bay, $65 \mathrm{MWe}$, shut down $7 / 2 / 76$ pending a decision on whether to make seismic and other modifications or to decommission.

- Three Mile Island 1, 819 MWe, shut down in accordance with a Nuclear Regulatory Commission (NRC) restraining order pending completion of modifications and other actions related to the accident at Three Mile Island.

- Three Mile Island 2, $906 \mathrm{MWe}$, shut down since the accident of $3 / 28 / 79$.

- Dresden 1, 200 MWe, shut down 10/31/78 for upgrading of its emergency core cooling system and for chemical cleaning. Outage expected to last through mid-1986, according to the NRC.

2/ Does not include Indian Point 1, 265 MWe; the operating authority of this unit was revoked on $6 / 19 / 80$ by the NRC and the owner has submitted a decommissioning plan to the NRC.

3/ Shippingport $60 \mathrm{MWe}$, and N Reactor 850 MWe. 
Fort St. Vrain Reaches Full Power

The Public Service Company of Colorado announced that the 330 MWe Fort St. Vrain nuclear generating unit operated at 100 percent capacity on November 15, 1981, for the first time in its five-year operating history.

\section{Suspension of Diablo 1 Operating License}

On November 19, 1981, the Nuclear Regulatory Commission suspended the Diablo 1 fuel loading and low power testing license granted September 15, 1981, to the Pacific Gas and Electric Company. The license has been suspended pending review of safeguards against earthquake damage. The Commission has also ordered an independent audit of Pacific Gas and Electric's quality control safeguards at the facility.

\section{Cancellation of Nuclear Units}

On October 9, 1981, Union Electric Company announced cancellation of Callaway 2 rated at 1120 MWe. Union Electric's Board Chairman Charles J. Dougherty said, "We regret having to make the decision to cancel this unit, but we cannot expose our investors and customers to the financial risks and uncertainties inherent in its construction."

The Carolina Power \& Light Company announced on December 16 the cance1lation of Harris 3 and 4 rated at 900 MWe each. The utility cited projections for more conservation and reduced growth in power as reasons for the cancellation. 
On December 23, 1981, Public Service Electric and Gas Company Board of Directors announced cancellation of Hope Creek 2, rated at 1067 MWe. Reduced energy demand and problems in obtaining long-term financing were cited as reasons for the cancellation. Approval of the cost amortization plan is required by the New Jersey Board of Public Utilities.

\section{Rating Change}

The followirg rating change is noted:

$\begin{array}{lll} & \text { old } & \text { New } \\ \text { Fort Calhoun } & 490 & 478\end{array}$

\section{Criticality Time}

The cumulative criticality time of central station type civilian nuclear reactors in the U.S. totaled 434 years through August 1981. This statistic is based on the number of hours of criticality operation reported in NRC publication NUREG-0020 (Grey Book) for the reactors licensed by NRC to operate, plus the cumulative criticality time of the DOE-owned Shippingport and " $N$ " reactors, plus an estimated total of 16 years criticality time for the eight central station units permanently shut down. 
B. Summary of Licensed Operating Reactors

The U.S. Nuclear Regulatory Commission publishes monthly NUREG-0020

"Licensed Operating Reactors Status Summary Report" (Grey Book). The

information that follows, "Summary of Licensed Operating Reactors"

is taken from the September 1981 (Data as of August 1981) issue.

This information will now be included as a regular part of UPDATE.

SUMAMA OF LICENSED OPERATING REACTORS

Month of Auguet 1981

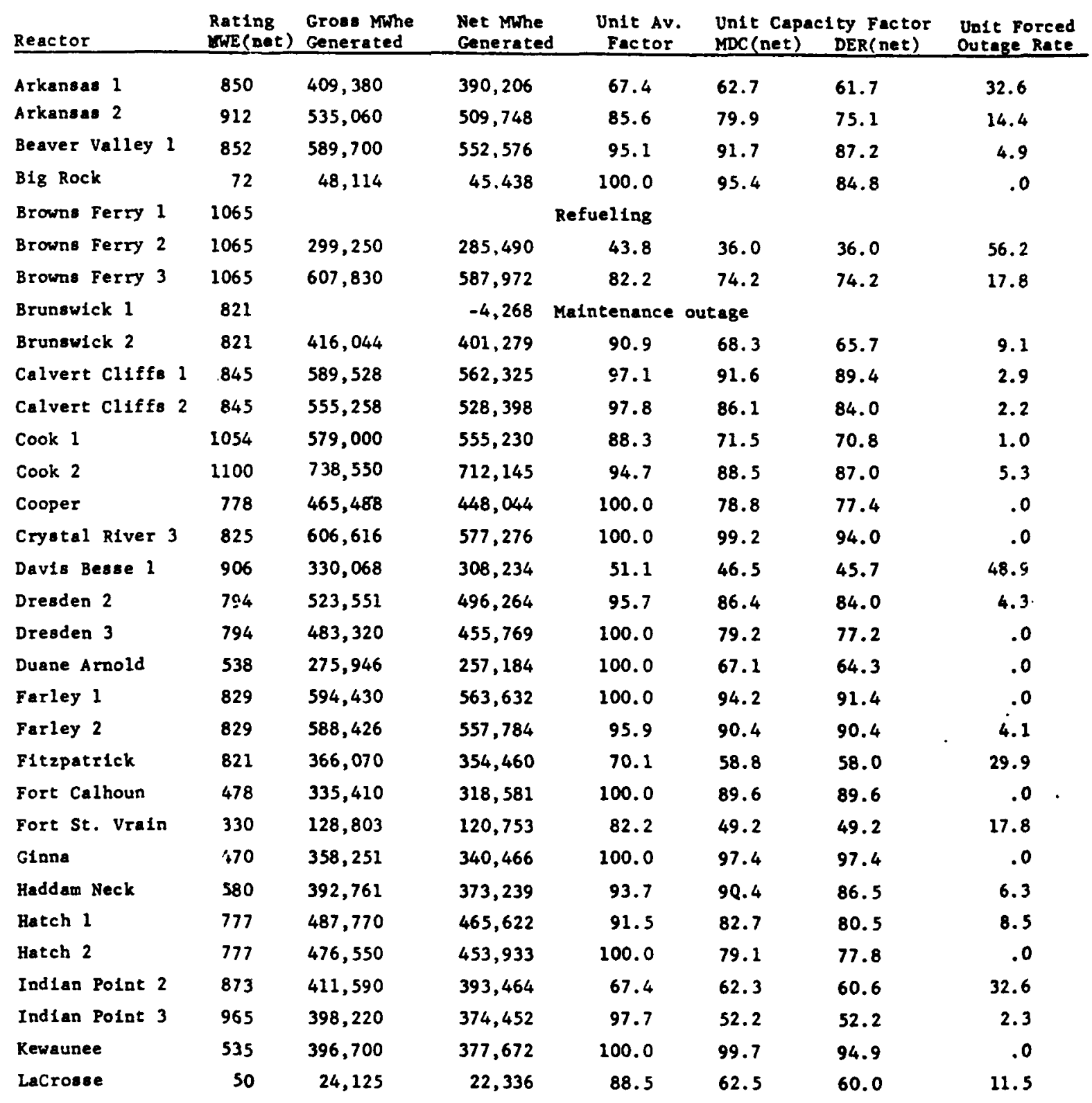




\begin{tabular}{|c|c|c|c|c|c|c|c|}
\hline Reactor & $\begin{array}{l}\text { Rating } \\
\text { MWe(net) }\end{array}$ & $\begin{array}{l}\text { Gross whe } \\
\text { Generated }\end{array}$ & $\begin{array}{l}\text { Net WWhe } \\
\text { Generated }\end{array}$ & $\begin{array}{c}\text { Unit Av. } \\
\text { Fncter }\end{array}$ & $\begin{array}{l}\text { Capacity } \\
\text { Mpc(net) }\end{array}$ & $\begin{array}{cc}\text { Factor } & \text { Uat } \\
\text { DER(net) Out }\end{array}$ & $\begin{array}{l}t \text { Forced } \\
\text { age Rate }\end{array}$ \\
\hline Maíne Yankee & 825 & 571,960 & 544,900 & 98.2 & 90.4 & 88.8 & 1.8 \\
\hline MeGuire 1 & 1180 & (completed & zero power pl & hysics \& low & power test 1 & ing 8-30-81) & \\
\hline Millstone 1 & 660 & 393,600 & 373,447 & 88.2 & 76.7 & 76.1 & 11.8 \\
\hline M1Ilstone 2 & 870 & 626,250 & 603,284 & 96.9 & 93.9 & 93.2 & 3.1 \\
\hline Monticello & 545 & 415,224 & 395,208 & 100.0 & 99.1 & 97.5 & .0 \\
\hline Nine Mile Point 1 & 620 & 446,733 & 433,016 & 100.0 & 95.4 & 93.9 & .0 \\
\hline North Anna 1 & 907 & 609,624 & 574,494 & 97.2 & 89.3 & 85.1 & 2.8 \\
\hline North Anna 2 & 907 & 185616 & 173,315 & 39.1 & 26.2 & 25.7 & 60.9 \\
\hline Oconee 1 & 887 & & $-2,338$ & Refueling & & & \\
\hline Oconee 2 & 887 & 648,100 & 619,432 & 100.0 & 96.8 & 93.9 & .0 \\
\hline Oconee 3 & 887 & 628,880 & 599,893 & 98.7 & 93.8 & 90.9 & 1.3 \\
\hline Oyster Creek & 650 & 119,610 & 111,030 & 45.4 & 24.1 & 23.0 & 54.6 \\
\hline Palisades & 805 & 258,150 & 238,708 & 60.3 & 50.5 & 39.9 & 39.7 \\
\hline Peach Bottom 2 & 1065 & 556,280 & 532,467 & 73.4 & 68.1 & 67.2 & .0 \\
\hline Peach Bottom 3 & 1065 & & $-8,740$ & Refueling & & & \\
\hline P1lgrtm 1 & 655 & 374,820 & 359,491 & 90.3 & 72.1 & 73.8 & 9.7 \\
\hline Point Beach 1 & 497 & 320,490 & 304,530 & 98.7 & 82.7 & 82.4 & .0 \\
\hline Point Beach 2 & 497 & 368,380 & 351.193 & 100.0 & 95.4 & 95.0 & .0 \\
\hline Pralrie Island 1 & 530 & 387,640 & 363,933 & 99.4 & 97.2 & 92.3 & .6 \\
\hline Prairle Island 2 & 530 & $387.14,0$ & 363,712 & 100.0 & 97.8 & 92.2 & .0 \\
\hline Quad Cities 1 & 789 & 509,292 & 471,079 & 97.4 & 82.3 & 80.2 & 2.6 \\
\hline Quad Cities 2 & 789 & 390,998 & 367,620 & 100.0 & 64.3 & 62.6 & .0 \\
\hline Rancho Seco 1 & 918 & 217,032 & 202,118 & 37.0 & 31.1 & 29.6 & 63.0 \\
\hline Robinson 2 & 700 & 458,831 & $-7,058$ & \multicolumn{3}{|c|}{ Steam Benerator repair \& inspection } & 100.0 \\
\hline Salem 1 & 1090 & 726,830 & 694,192 & 98.1 & 86.5 & 85.6 & $i .9$ \\
\hline Salem 2 & 1115 & 602,220 & 571,566 & \multicolumn{2}{|c|}{ In power ascension } & & \\
\hline San Onofre 1 & 436 & 123,000 & 114,321 & 47.3 & 35.2 & 35.2 & 52.7 \\
\hline Sequoy ah 1 & 1128 & 501,970 & 478,176 & 64.9 & 57.0 & 57.0 & 35.1 \\
\hline St. Lucle 1 & 802 & 612,560 & 579,344 & 100.0 & 100.2 & 97.1 & 0 \\
\hline Surry 1 & 788 & 559,940 & 528,777 & 96.9 & 92.7 & 90.2 & 3.1 \\
\hline Surry 2 & 788 & 574,105 & 543,191 & 100.0 & 94.2 & 92.7 & .0 \\
\hline Three Mile Ioland & 1 Regul & atory restra & aint order in & effect follo & wing accide & lent at unit 2 & 100.0 \\
\hline Trojan & 1130 & 773,690 & 733,930 & 99.0 & 91.3 & 87.3 & 1.0 \\
\hline Turkey Point 3 & 693 & & $-1,495$ & Steam generat & tor repair & & \\
\hline Turkey Point 4 & 693 & 513,095 & 487,956 & 99.5 & 101.5 & 94.6 & .5 \\
\hline
\end{tabular}




\begin{tabular}{|c|c|c|c|c|c|c|c|}
\hline Reactor & $\begin{array}{l}\text { Rating } \\
\text { MWe(net) }\end{array}$ & $\begin{array}{l}\text { Gross MWhe } \\
\text { Generated }\end{array}$ & $\begin{array}{l}\text { Net MWhe } \\
\text { Genersted }\end{array}$ & $\begin{array}{l}\text { Unit Av. } \\
\text { Factor }\end{array}$ & $\begin{array}{l}\text { Unit Cap } \\
\text { MDC (net) }\end{array}$ & $\begin{array}{c}\text { 1ty Factor } \\
\text { DER(net) }\end{array}$ & $\begin{array}{l}\text { Unit Forced } \\
\text { Outage Rate }\end{array}$ \\
\hline Vermont Yankee & 514 & 373,797 & 351,032 & 100.0 & 93.6 & 91.8 & .0 \\
\hline Yankee-Rowe & 175 & 103,880 & 96,293 & 97.8 & 74.0 & 74.0 & 2.2 \\
\hline Zion 1 & 1040 & 779,550 & 751,278 & 100.0 & 97.1 & 97.1 & .0 \\
\hline $2 \operatorname{lon} 2$ & 1040 & 478,625 & 451,103 & 97.3 & 58.3 & 58.3 & 19.9 \\
\hline
\end{tabular}

Augus 1981

Avg. Unit Avallability ( $\bar{x}$ )

Avg. Unit Cap Factor (MDC \%)

Avg. Unit Cap. Factor (DER \%) 679

Forced Outage Rate $(\%) \quad 12.5$
GLOSSARY (NUREG-0020)

Maximum Dependable Capacity (MDC) (MWe)

Design Electrical Rating (DER) (IWe)

Gross Electrical Energy Generated (MWhe)

Net Electrical Energy Generated (MWhe)

Unit Availability Factor

Unit Capacity Factors

- Using DER

-- Using MDC

Unit Forced Outage Rate
The dependable main unit capacity, winter or summer, whichever is smaller.

The nominal net electrical output of the unit specified by the utility and used for the purpose of plant design.

Electrical output of the unit during the report period as measured at the output terminals of the turbine generator, in megawatts hours.

Gross electrical output of the unit measured at the output terminals of the turbine generator during the reporting period, minus the normal station service electrical energy utilization. If this quantity is less than zero, a negative number should be recorded.

Untt Avallable Hours x 100

Period Hours

Net Electrical Energy Generated x 100 Period Hours $x$ DER

Net Electrical Energy Generated x 100 Period Hours $x$ MDC Net

Forced Outage Hours Unit Service Hours + Forced Outage Hours

Excludes Dresden 1, Humboldt Bay, and Three Mile Island 2 which are licensed for operation and are shut down indefinitely. 


\section{Revitalizing Nuclear Power Plant Design and Construction: Lessons Learned by TVA}

During an AIF "Workshop on Reactor Construction and Operation" held in Chicago during October 1981, the Tennessee Valley Authority (TVA) presented a paper entitled "Revitalizing Nuclear Power Plant Design and Construction: Lessons Learned by TVA". In this paper, TVA reviewed its experience in the design and construction of nuclear power plants dating back to the late 1960 's and identified reasons for nuclear power's cost increases and schedule delays. The following are excerpts from the paper.

\section{An Appraisal of the Situation}

"It is easy to identify, in a general way, the underlying problems of the industry. The causes of the problem are many and are more difficult to identify. The solutions are even more difficult, controversial, and complex.

"The underlying problem is that nuclear plants cost more than they should, take longer to build than is reasonable, and are a large and risky investment because of the uncertainty in estimating the final cost and operating dates. These are the issues which the industry must address if it is to be revitalized.

"Design and construction of a nuclear plant are more complex than for a fossil plant. The increased complexity required to design and construct a nuclear plant stems primarily from the fact that the analyses (including accident analyses) are more sophisticated, 
seismic analysis is a complicating requirement, there is a much greater need for documenting activities and for demonstrating a higher degree of assurance that all aspects of design and construction are correct, and requirements continue to change at a very rapid rate.

"The result is that the man-hours required to design a nuclear plant are much greater than required to design a fossil plant. Figure I illustrates TVA experience.

"This perhaps illustrates better than anything else the effect of changing requirements. The real question in our minds is, 'Has the benefit justified the cost?' There are similar increases in the man-hours required to construct the plants, as shown in Figure 2. Unquestionably, this increased effort has been the biggest contributing factor in the large schedule delays and the large cost increases which we have experienced, as shown in Figure 3.

\section{Planning, Scheduling and Cost Control}

"The very fact that the effort in design and construction is so large means that coordination between persons and organizations is multiplied many times, and control of the overall effort is much more difficult. Better planning, scheduling, and cost control are essential to cope with this situation. TVA has developed and is continuing to develop more sophisticated project control methods and techniques. We have developed a computerized scheduling program 


\section{FIGURE 1}

\section{DESIGN MAN-HOURS FOR \\ TVA NUCLEAR PLANTS}

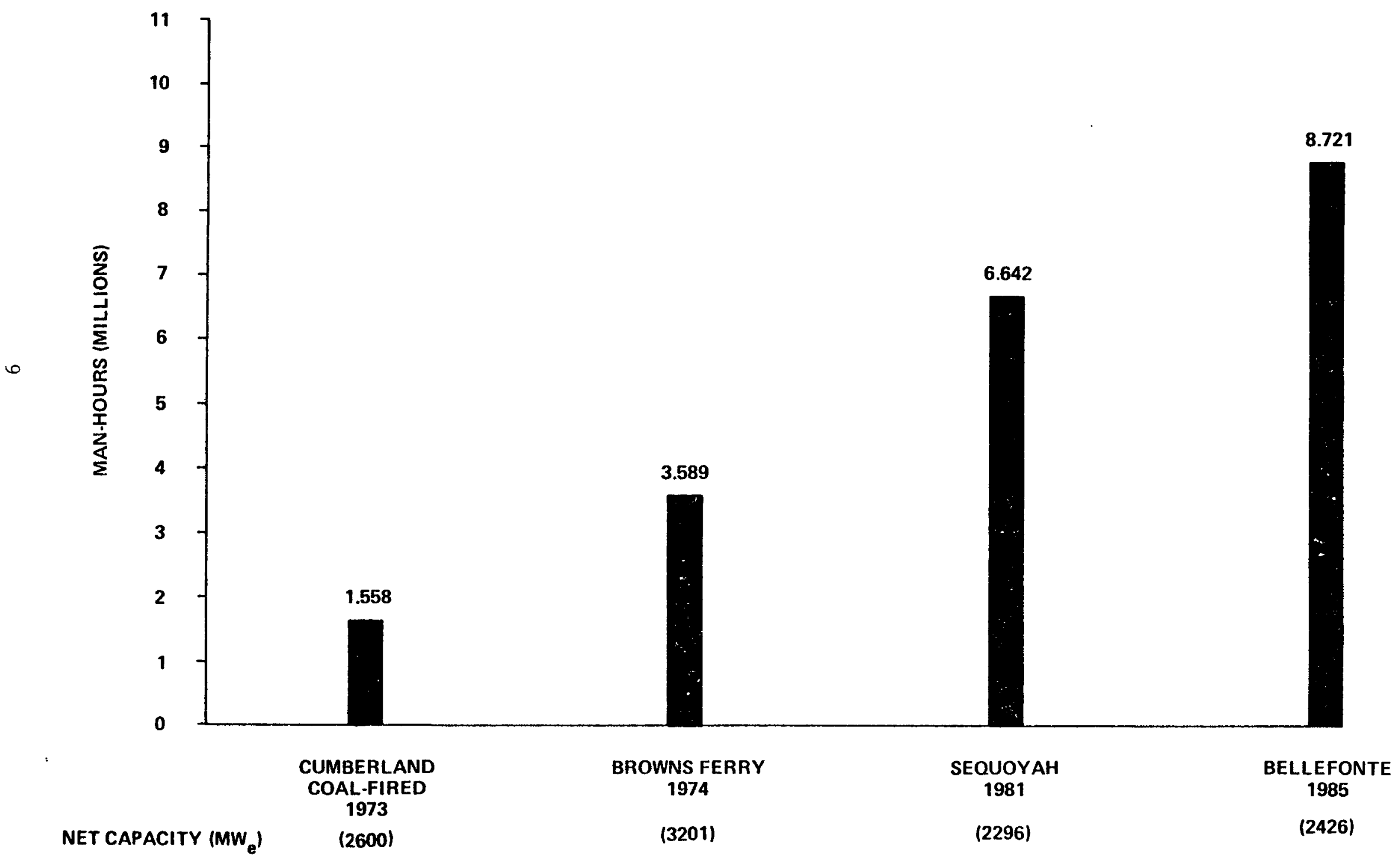


FIGURE 2

CONSTRUCTION MAN-HOURS FOR

TVA NUCLEAR PLANTS

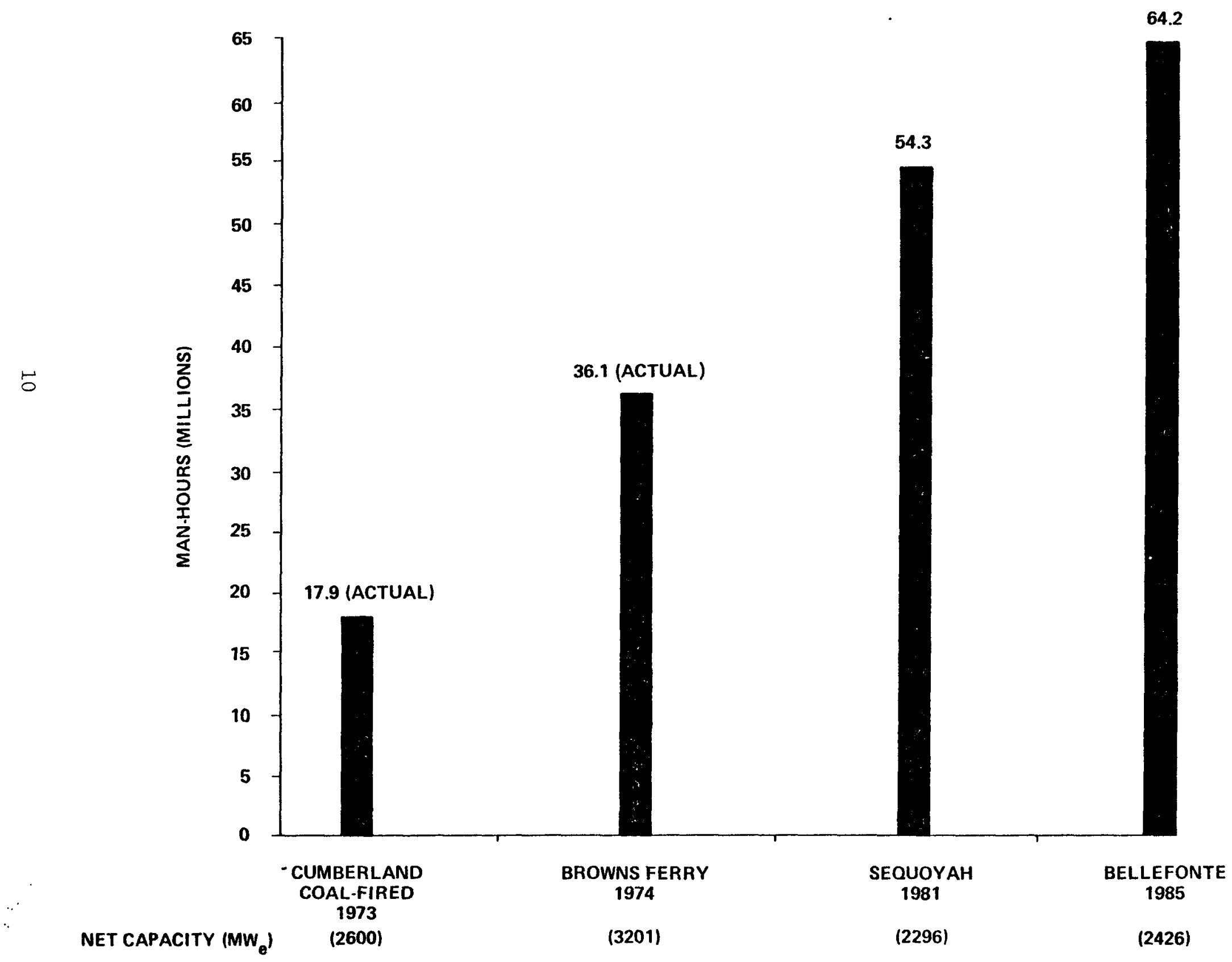




\section{FIGURE 3 \\ TVA NUCLEAR PLANT COST $\$ / \mathrm{kW}$ (NORMALIZED TO 1981 DOLLARS) *}

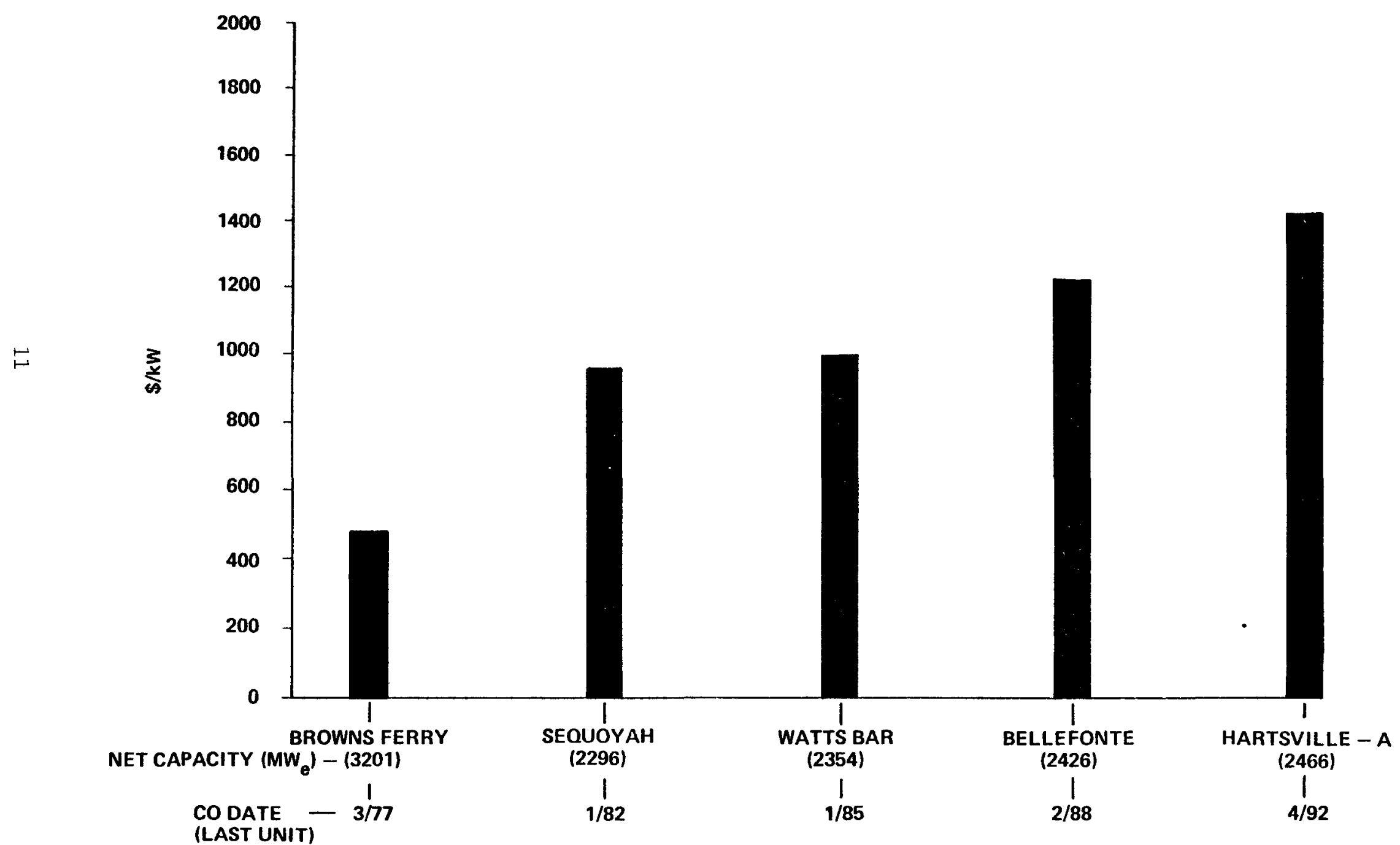

"EXCLUDING INTEREST 
called PC-III. This system integrates design, procurement, and construction activities.

\section{Quality Assurance}

"TVA is now working hard to increase the effectiveness of its quality assurance program and to improve the quality of design and construction. We believe we have the organizational commitment and the resources required to implement the program. However, our efforts have not yet reached down to the level where the work is being accomplished. Worker attitude is not the major problem in this respect, although clearly we see problems in maintaining pride of workmanship under an atmosphere of close inspection and review, detailed cookbook procedures, and rapidly changing requirements. We believe the problem of making quality effective at the working level is primarily one of understanding and training.

\section{Standardization}

"Standardization includes the concept of using modular systems which reduce field construction effort.

"In using standardized designs, there are two important lessons which we have learned. First, a design is not standard until the design has been essentially completed and licensed and the construction has been proven. In fact, a standard design is not truly a standard until it has been proved in operation. TVA is convinced of the need for further standardization, but our experience to date 
has not been without problems. Problems with first-of-a-kind standard designs have burned us badly. Second, there is no such thing as a completely standard design unless the plant uses identical equipment throughout. We have learned by experience that design details-including specific equipment design, configuration, and connections-have a greater impact than we anticipated, and that a much higher percentage of the total design effort is devoted to such details of a nuclear plant than a fossil plant. Much of our rework and late changes have been related to design details. A completely standard design presupposes total use of identical equipment, and any exceptions require a disproportionately high amount of detail design time.

\section{Design Overlap of Construction}

"This inability to complete design in a time which allows construction to proceed to completion without numerous changes and interruptions has been a major problem for the industry. It has become clear that the construction phase of a nuclear plant cannot overlap the design phase nearly as much as is possible with a fossil plant. However, as pointed out earlier, a larger percentage of the design effort is devoted to detail design; and in order to bring the design to an advanced stage of completion, equipment information details must be known. This means that equipment must be bought early and may result in early delivery and long-term storage, which is very expensive. To minimize this problem, we have been reasonably successful in awarding contracts with delayed delivery. 


\section{Conservative Design}

"Even though standardization may to a large extent be achieved, there will still be a significant number of changes during the design and construction of a nuclear unit. We have learned that one of the more effective approaches to minimizing the impact of these inevitable changes is by exercising conservatism in the original design.

"Another area in which conservative design must be applied is space allocation within buildings. The traditional approach for controlling costs by minimizing the volume has caused some very serious difficulties in construction because of extremely congested areas.

\section{Over Commitment}

"Much attention should be given to the review of codes, standards, and regulatory guides prior to making commitments to abide by them. These commitments are made early in the planning process, usually without ample consideration to their total applicability and the ability of either the designer or constructor to meet them to the letter. Many codes and standards were contrived and written by wel1-qualified, well-meaning individuals projecting ideal situations. They never had any idea that in this day and age of rigid quality assurance and quality control, the codes and standards would be enforced to the letter.

"Currently within TVA we are finding that we cannot construct to the tolerances of certain codes to which we are committed; thus, we are in the process of developing internal documents which comply with the 
intent of the code but which are interpretations containing sufficient latitude to permit construction. For example, it would be much easier and simpler to perform an adequate review initially and make the proper partial commitment than to go back and get the commitment changed at a later time.

\section{Control of Changes}

"In order to build a nuclear project on schedule and within budget, there must be strict control over design changes which result in construction delays or modifications, additions, or rework to already completed features. At TVA's Sequoyah plant, scope changes and design changes caused the greatest impact on schedules and costs. Some items required removing structures and material which were completed or near completion. Other items caused holds to be placed on ongoing work or delayed the start of other work. Figure 4 indicates the volume of Engineering Change Notices for Sequoyah.

\section{Unitized Design}

"We have learned through costly and bitter experience that each unit of a multiple-unit plant must be identical and slide-along--i.e., not opposite hand (incorporate changes as needed, not an exact mirror image). TVA's first four plants (Browns Ferry, Sequoyah, Watts Bar, and Bellefonte) utilized various degrees of sharing. Use of shared equipment and systems between units very much complicates the safety analysis and results in costly provisions to prevent interaction between units. Security provisions during startup of the second unit, including strict limitations on the number of construction persons in the operating units area, are very costly; and 
FIGURE 4

SEQUOYAH NUCLEAR PLANT ENGINEERING CHANGE NOTICES

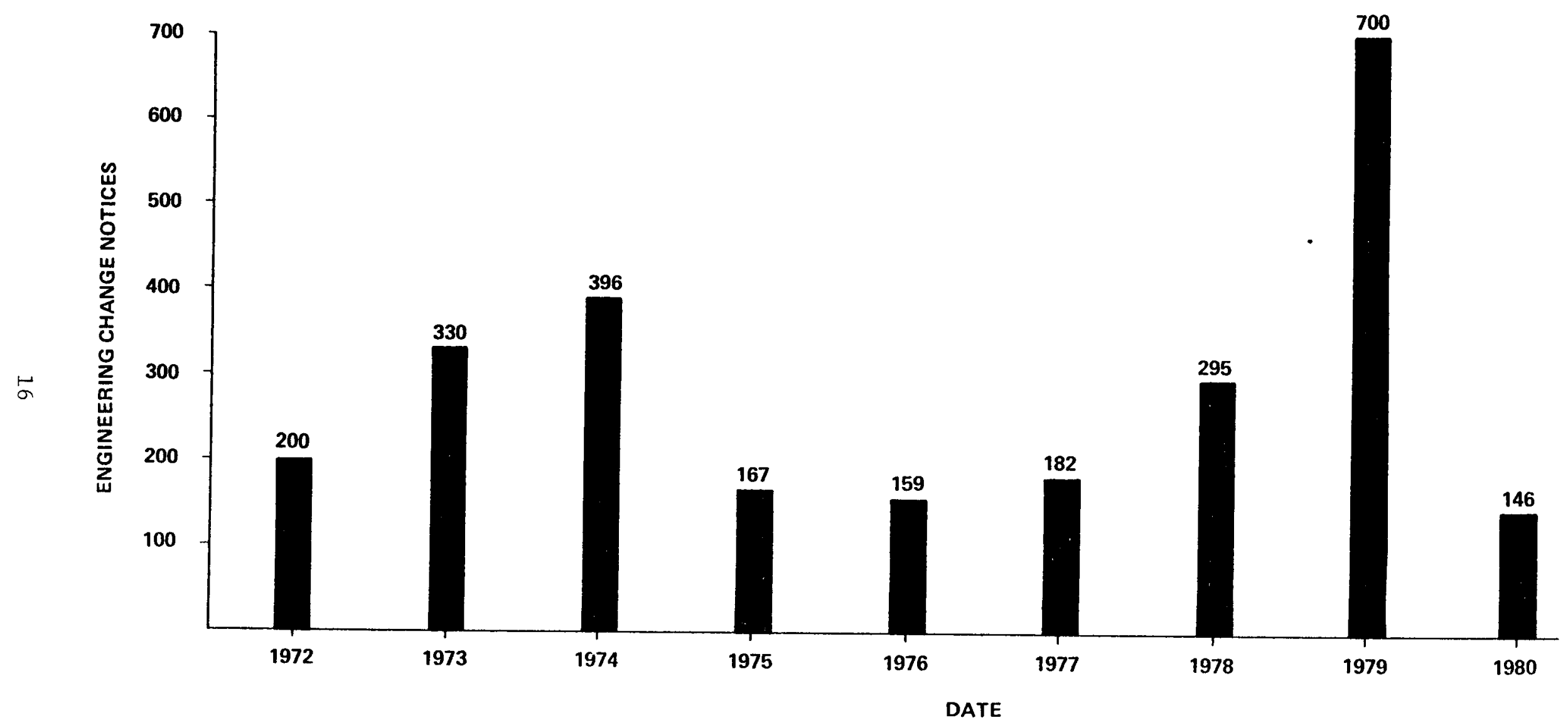


we are still paying the price of shared systems and equipment during operation because of technical specification outage limits that affect all units. We are currently facing a two-unit outage at Sequoyah because of the need to make changes to shared systems.

\section{Safety Analysis}

"Revitalization of the nuclear industry requires that we address the question of 'How safe is safe enough?' and evaluate the effects of changes in regulations and their real safety benefits.

"We firmly believe that establishing safety goals and continuing development of Probabalistic Risk Assessment (PRA) techniques are necessary to provide rationale and consistency in evaluating changes which are proposed as improvements to safety. In this way, we will be able to apply our resources to the dominant risks.

\section{Revitalizing - An Industry Effort}

"In TVA, we are struggling mightily to keep our best expertise and talent focused on the truly important issues of safety and quality. This is admittedly a difficult problem, for it requires far less perception and expertise to deal with the trivia than it does to identify which of the issues are genuinely significant. The ability to focus on the significant issues may indeed be the key to revitalizing the industry." 


\section{NERC's Electric Power Projections for 1981-1990}

The National Electric Reliability Council (NERC) recently released its "11th Annual Review of Overall Reliability and Adequacy of the North American Bulk Power Systems", dated August 1981. NERC's present assessment for the $1980^{\prime}$ 's is that electric utilities have a power supply program which should provide adequate and reliable electric service based on current perceptions of what future requirements will be. However, they feel this decade is overshadowed with uncertainty on both the demand and supply side of the electric energy equation and these present perceptions may change and adjustments to the program may be necessary. We present below excerpts from the NERC review regarding the nation's future power supply program and its outlook for nuclear generating supply capacity.

\section{Future Power Supp1y Program}

"Based on current peak demand and energy forecasts (average growth ner year of $3.4 \%$ and $3.7 \%$ for peak demand and energy use respectively) for the 1981-1990 period, utilities in the United States are forecasting the need to install approximately 183,000 MWe of new base load generating capacity. This includes approximately 83,000 MWe of nuclear and 100,000 MWe of coal-fired capacity. Figure $1 \frac{1 /}{}$ shows the additions on a year-by-year basis, specifying those presently uncier construction and in various stages of planning, design or licensing.

"The total generating capacity by type, planned to be in service each year during the next ten years, is shown in Figure 2. In addition to

1/ Figure numbers have been changed for editorial purposes. 


\section{NORTH AMERICAN ELECTRIC RELIABILITY COUNCIL}

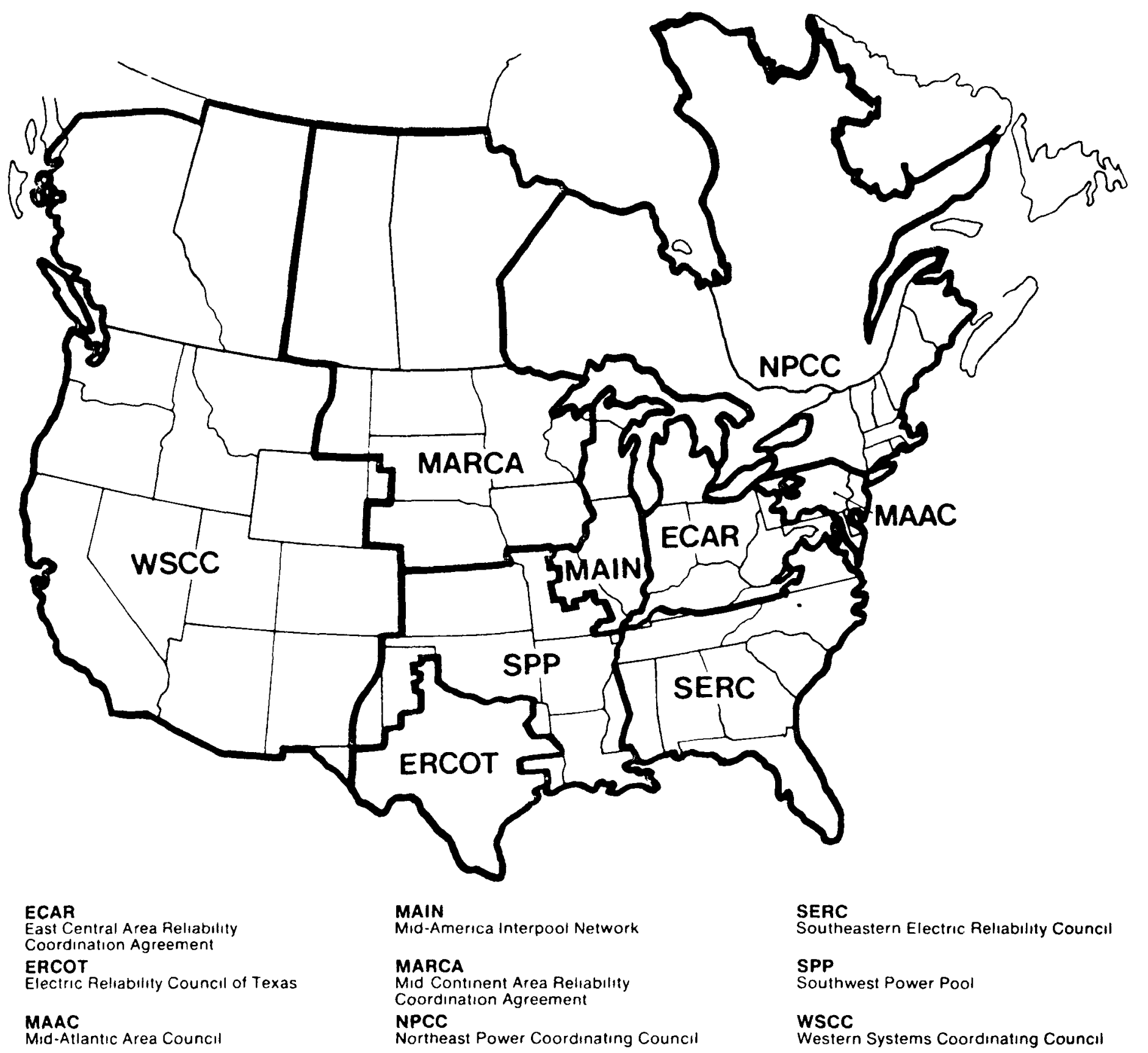

The North American Electric Reliability Council (NERC) was formed by the electric utility industry in 1968 to promote the RELIABILITY and ADEQUACY of bulk power supply in the electric utility systems of North America NERC consists of nine Regional Reliability Councils encompassing essentıally all of the power systems in the United States and most of the systems in Canada

RELIABILITY and ADEQUACY are separate but interdependent aspects of the bulk power supply system of the electric utility industry in North Americd RELIABILITY involves the security of the interconnected transmission network and the advoidance of uncontrolled cascading tripouts which may result in widespread power outages ADEQUACY refers to having sufficient generatıng capability at all times to be able to meet the aggregate electric peak loads of all customers and to supply all their electric energy requirements 
NERC (US)

MAJOR COAL AND NUCLEAR GENERATING UNIT ADDITIONS

THOUSANDS OF MV.

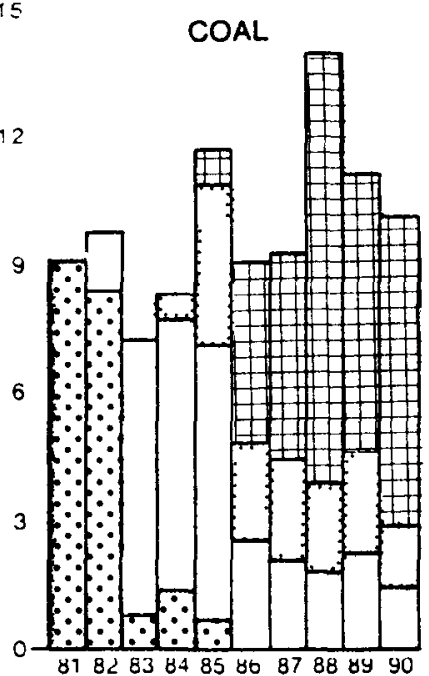

$\therefore$ Under construction, more than $50 \%$ complete Utility authorized, but not under construction

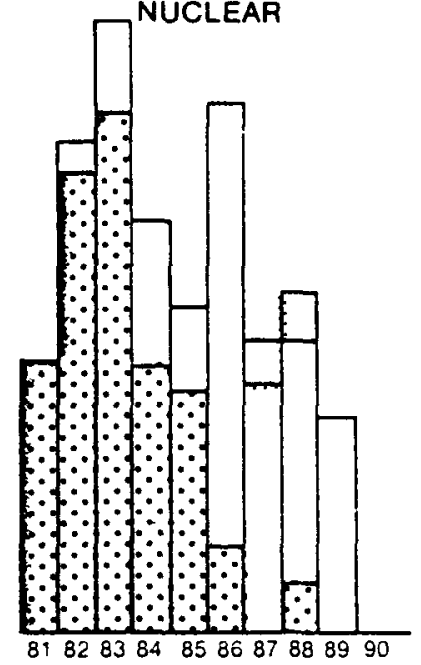

$\square$ Under construction. less than $50 \%$ complete Planned for installation,
but not utility authorized
NVERC (U S) - TOTAL GENERATING CAPABILITY BY PRINCIPAL FUEL SOURCES ISUMMER

HHOUSANDS OF MV

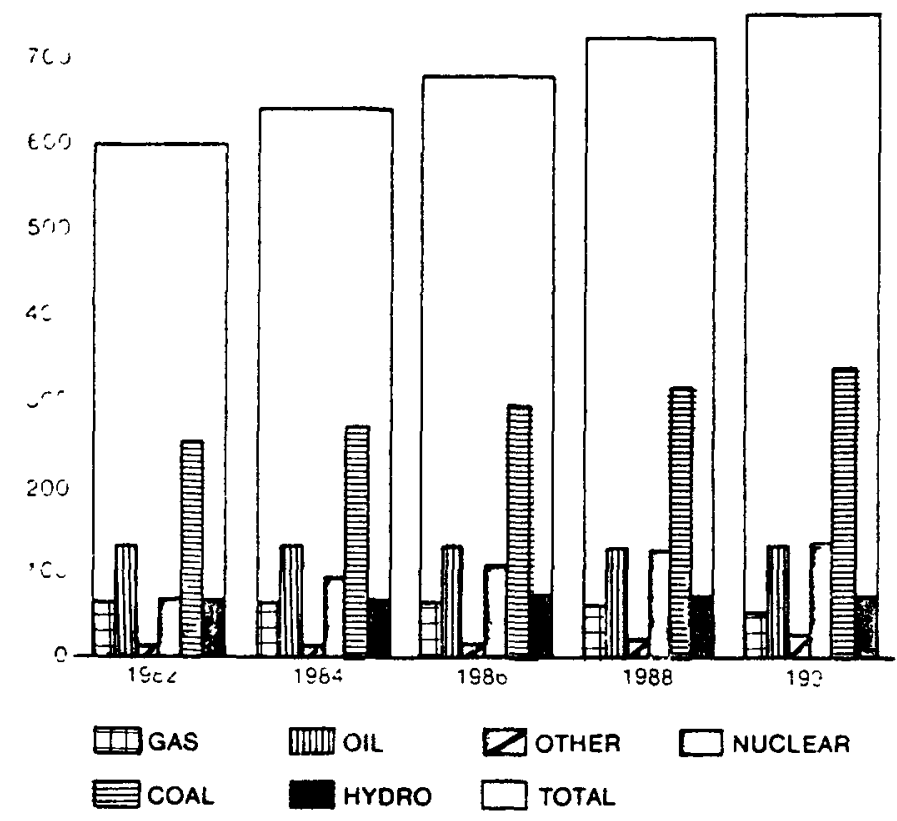

FIGURE 2 
the new base load coal-fired and nuclear capacity, almost 8,400 MWe of existing base load oil-fired capacity has been identified for conversion to coal firing.

"Supplementing this base load capacity, over 11,200 Me of cogeneration and renewable energy resources are included in the planned resource program for the 1981-1990 period. This includes over 7,200 MW of hydro, 2,100 MW of geothermal, and 1,900 MW in the form of solar, wind, cogeneration and biomass.

"The installation of nuclear and coal-fired generating capacity, in conjunction with oil-to-coal conversions, conservation and load management, is the only prudent strategy for the 1980's to assure adequate electric energy supply and to reduce the use of oil and gas for electric generation. Even with the successful completion of this program, oil- and gas-fired capacity will still represent nearly $13 \%$ of the nation's total generating capacity in 1990 . Electric energy production by principal energy sources is shown in Figures 3 and 4 .

"In 1981, oil is projected to produce about $11 \%$ of the nation's electric energy requirements, requiring about 1.1 million barrels of oil per day (mbd). This amounts to less than $10 \%$ of the nation's total oil requirements. 


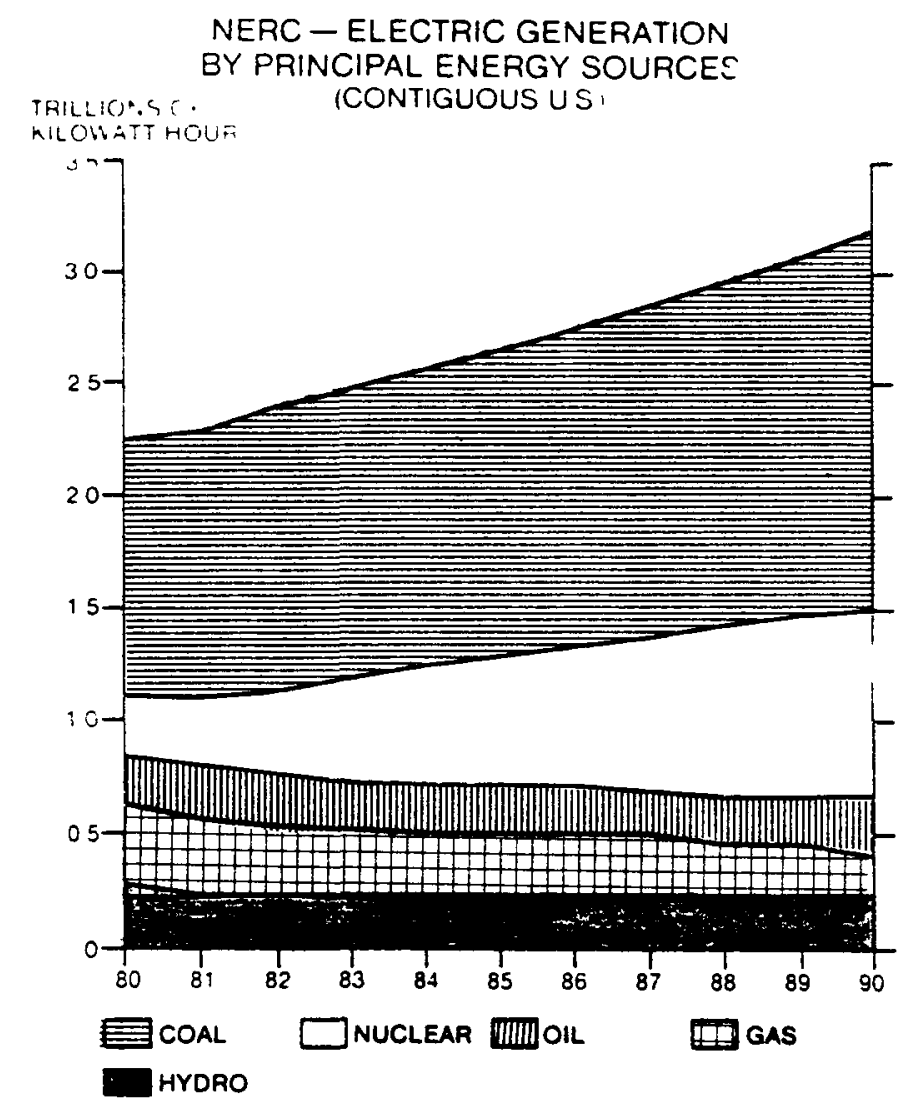

FIGURE 3

NERC - ELECTRIC GENERATIOI.

PERCENTAGES BY PRINCIPAL ENERGY SOURCES ICONTIGUOUSUS
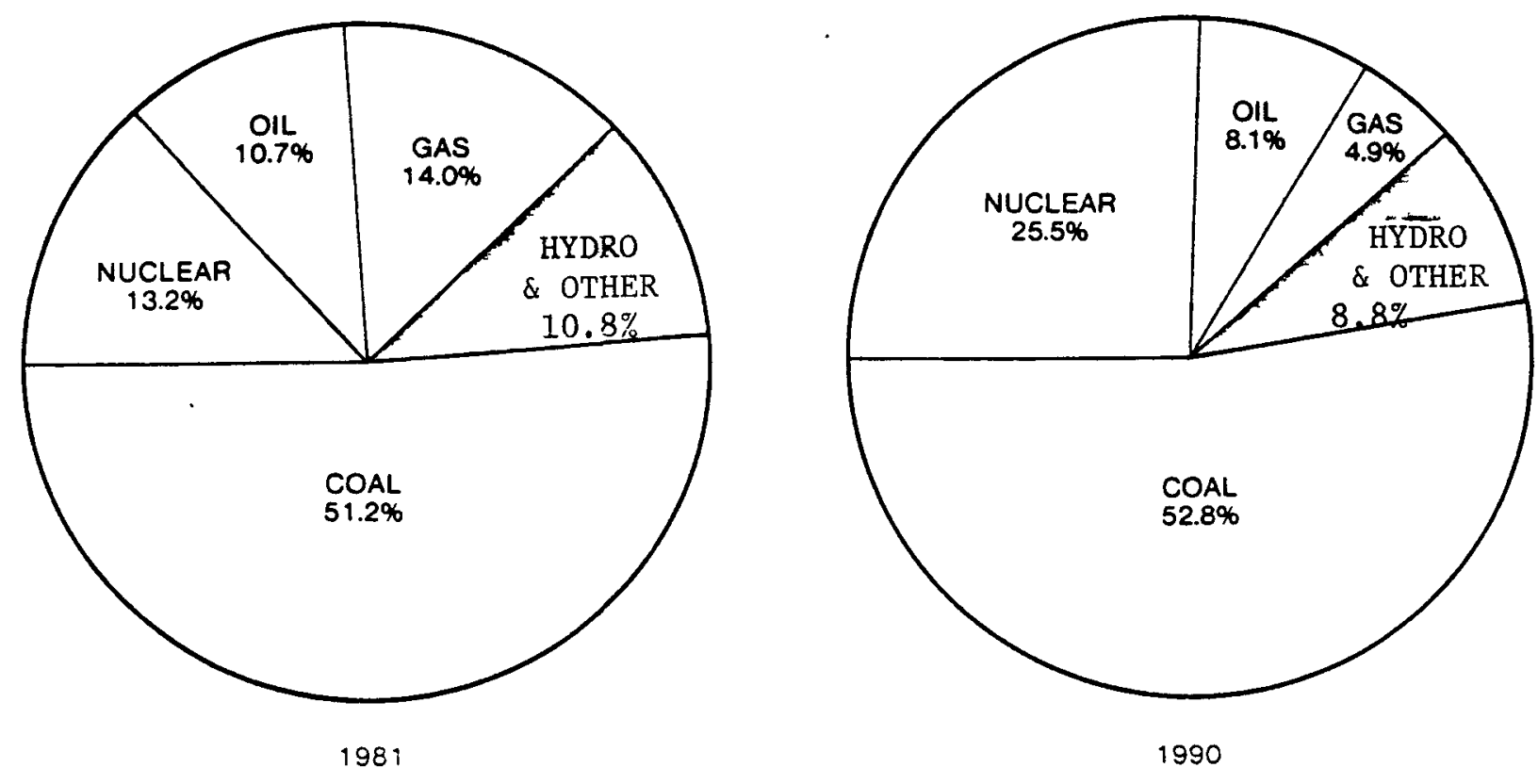
"Oil usage for electric generation is concentrated as follows:

Electric Energy

from $0 i 1$

Subregion/Region

(1981 Forecast)

New England (NPCC)

$57 \%$

Florida (SERC)

$53 \%$

New York (NPCC)

$31 \% *$

California-Nevada (WSCC)

$31 \%$

MAAC

$13 \%$

*Would be approximately $40 \%$ except for temporary permission to burn natural gas.

"As a result of this dependence, these areas remain extremely vulnerable to any forced curtailment of oil supply.

"About $14 \%$ of the nation's 1981 electric energy is expected to be produced from natural gas. This usage represents an oil equivalent of $1.5 \mathrm{mbd}$. Natural gas usage for electric generation is concentrated in the ERCOT and SPP regions, representing $65 \%$ and $56 \%$, respectively, of their total expected electric energy generation in 1981.

"Because certain generating facilities are designed to operate on either oil or natural gas, it is convenient to consider their use on a combined basis. In 1981 , oil and natural gas are projected to provide $25 \%$ of the total U.S. electric energy production, requiring an oil equivalent of $2.6 \mathrm{mbd}$. By 1990 , electric energy production from the combination of oil and gas is expected to decline to $1.9 \mathrm{mbd}$, as shown in Figure 5, a reduction of almost 30\% from 1981 requirements. As such, the portion of 1990 electric energy production from these fuels is projected to be only $13 \%$. 


\section{NERC \\ OIL/GAS REQUIREMENTS \\ (CONTIGUOUS U.S.)}

MILLION BBLS PER DAY

OIL EQUIVALENT

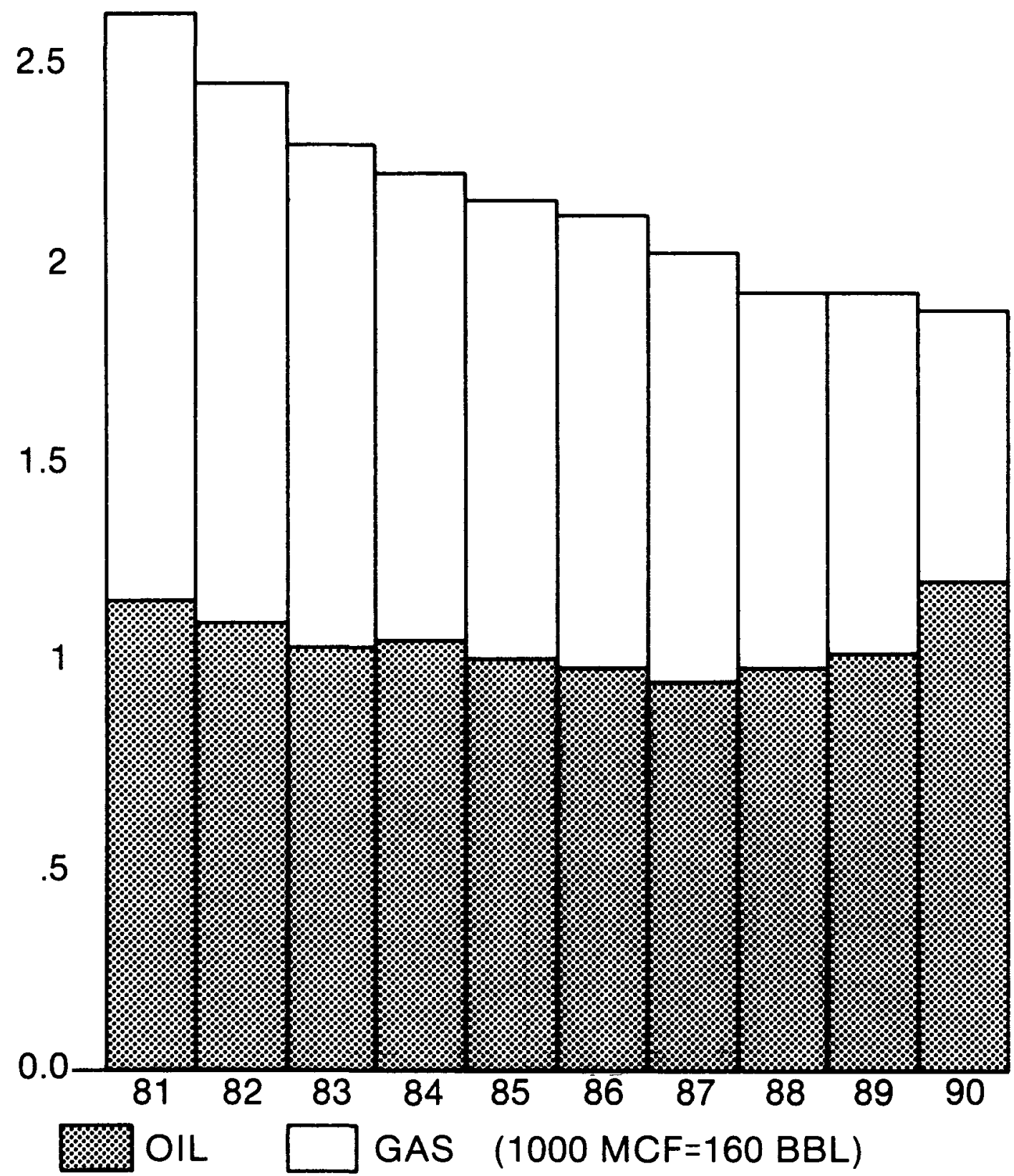

FIGURE 5 
The Outlook for Nuclear Generating Capacity

"The 83,000 MW of nuclear capacity scheduled for service during the next decade represents about $45 \%$ of the capacity additions required to meet expected peak demand and electric energy requirements reliably. More importantly, this capacity is an essential element in assuring energy independence and adequacy in the future. For those regions and subregions heavily dependent on foreign-based oil supply--namely, NPCC, MAAC, SERC/Florida, and WSCC/CaliforniaNevada--the addition of nuclear capacity represents an essential step in reducing the use of oil for electric generation. In ERCOT and SPP, nuclear capacity additions are a significant part of the strategy to reduce the use of natural gas for electric generation.

"Most of the 83,000 MW of nuclear capacity expected in service by 1990 is presently under construction and represents projects which were committed several years ago. Although this program is well underway, the present financial, political and regulatory climate is such that serious concerns exist as to whether these units can and will be installed in accordance with current industry schedules. Considering that the energy to be supplied by the nuclear capacity additions planned during the 1980 's is equivalent to 850 million barrels of oil per year or $2.3 \mathrm{mbd}$, this program must be kept on schedule.

"The political and regulatory climate surrounding nuclear energy is so uncertain that most utilities today are unwilling to commit to a new nuclear project. In fact, during the last three years, 35 units 
representing about 39,000 MW of capacity, were cancelled or postponed indefinitely. In contrast to the United States' situation, Canada and other countries are vigorously pursuing a nuclear program as their primary strategy for reducing oil dependence.

"A fundamental issue facing nuclear energy is the public's apprehension regarding safety. As a result, the viability of nuclear energy as an option for additional electric power supply, beyond those units already existing or committed, is in serious jeopardy." 
E. Electrical World's Forecast of Peakload and Capital Expenditures In its September 1981 edition, 1 / Electrical World (EW) forecast a reduced growth in peak demand through the remainder of the 1980's and a moderation of the upward spiral of capital expenditures for coal and nuclear plants. Their projection of an annual peak demand growth rate of 3.2 percent is a bit lower than the 3.4 percent given by NERC in the previous article and a bit higher than the DOE midrange projection to 1990 of 3.0 percent reported in the last issue of UPDATE. $2 /$ EW feels that the consumption of electricity is now inexorably tied to the U.S. economy and this tie underlies its energy forecast. Below are excerpts from Electrical World's forecast in relation to peakload growth and capital expenditures for the electric utility industry.

"After a year of high growth in peak demand (6.8 percent in 1980 as shown on Table 1), a year of low growth usually follows. Actual growth (in 1981), however, was even lower than (EW) expected, primarily because the economic recovery that (EW) anticipated simply did not materialize. Weather was normal throughout the country, as was irrigation load; this resulted in a mere blip in the growth curve, which was up about $0.4 \%$.

"Based on the prospects of a more advantageous tax structure, slackening inflation, and moderating interest rates, there should be a boost in demand (in 1982)--though it will still be only a modest one. A $4 \%$ overall national rise in peak for 1982 seems well within reason.

1/ "32nd Annual Electrical Industry Forecast," Electrical World Magazine, September 1981, Volume 195, Number 9, page 73, Published by McGraw-Hill. 2/ Reported in the July-September Issue of UPDATE, page 25. 
"Longer term, though, a decreasing pattern in rate of growth still appears in the cards. We feel that a normalized compound annual rate of about $3.2 \%$ should be maintained through the rest of the $80^{\prime} \mathrm{s}$.

\section{Table 1}

Total sales, output, peak load, capability, and margin

$\begin{array}{lcccccc}\text { Total } & \begin{array}{c}\text { Total } \\ \text { sales, } \\ \text { bilition kWh }\end{array} & \begin{array}{c}\text { Annual non- } \\ \text { billion kWh } \\ \text { coin. peak, } \\ \text { mililon kW }\end{array} & \begin{array}{c}\text { Capability } \\ \text { at peak, } \\ \text { million kW }\end{array} & \begin{array}{c}\text { Gross } \\ \text { peak } \\ \text { margin, \% }\end{array} & \begin{array}{c}\% \\ \text { peak } \\ \text { growth }\end{array} \\ 1970 & 1,3914 & 1,5416 & 2754 & 3278 & 187 & 66 \\ 1971 & 1,4664 & 1,6229 & 2931 & 3546 & 209 & 64 \\ 1972 & 1,5777 & 1,7585 & 3202 & 3830 & 196 & 92 \\ 1973 & 1,7032 & 1,8756 & 3449 & 4168 & 208 & 77 \\ 1974 & 1,7008 & 1,8790 & 3493 & 4444 & 272 & 13 \\ 1975 & 1,7330 & 1,9298 & 3568 & 4793 & 343 & 21 \\ 1976 & 1,8496 & 2,0510 & 3709 & 4988 & 345 & 40 \\ 1977 & 1,9508 & 2,1456 & 3949 & 5171 & 310 & 65 \\ 1978 & 2,0178 & 2,2323 & 4081 & 5457 & 340 & 33 \\ 1979 & 2,0792 r & 2,2831 r & 4090 & 5575 & 363 & 03 \\ 1980 & 2,0953 & 2,3212 & 4371 & 57112 & 306 & 68 \\ & & & & & & \\ 1981 & 2,1326 & 2,3458 & 4388 & 5849 & 333 & 04 \\ 1982 & 2,2023 & 2,4226 & 4564 & 6096 & 334 & 40 \\ 1983 & 2,3126 & 2,5415 & 4726 & 6353 & 344 & 35 \\ 1984 & 2,4094 & 2,6479 & 4886 & 6511 & 333 & 34 \\ 1985 & 2,5016 & 2,7492 & 5050 & 6744 & 335 & 34 \\ 1986 & 2,5899 & 2,8437 & 5217 & 6924 & 327 & 33 \\ 1987 & 2,6824 & 2,9453 & 5386 & 7041 & 307 & 32 \\ 1988 & 2,7775 & 3,0497 & 5559 & 7181 & 292 & 32 \\ 1989 & 2,8729 & 3,1545 & 5735 & 7242 & 263 & 32 \\ 1990 & 2,9703 & 3,2600 & 5916 & 7311 & 236 & 32 \\ 1995 & 3,4542 & 3,7910 & 6878 & 8120 & 180 & 30 \\ 2000 & 3,9768 & 4,3645 & 7946 & 9372 & 179 & 29\end{array}$

'Peak for 1980 is actual minus interruptiols load as reported by the National Electric Rehabibty Counclis Eloctinc Power Supply \& Demend hly 1981 plus the demand of systems not reporting to NERC

2Capabitty for 1980 calculated as in footnote (1) above

Reprinted from September 1981 issue of Electrical World (C) Copyright 1981, McGraw-HIII, Inc. All rights reserved 


\section{Capital Expenditures}

"The combination of the loss of a year's load growth in 1981 and (EW's) somewhat reduced long-term forecast of future load growth will have a substantial effect on generation construction over the entire period of the forecast. It means the rescheduling--and, in some few cases, the cancellation--of units now planned for completion in the late 1980s. Over the longer term, the revised schedule translates into elimination of several major units in the late '90s.

"The stretched-out schedule also means stretched-out capital expenditures for the short-term, and an altered pattern of expenditures for generation throughout the next two decades (see Table 2). Fewer units will be completed in the very late' 80 s, as the current round of units already under construction runs out, and the next has not yet peaked. The nadir of capital outlay for generation will be reached--touching a low of (approximately) \$l4-billion (in 1981 dollars) in 1987.

Electrical World states, "that the very substantial upward ramping of cost per $\mathrm{kW}$ for both coal and nuclear units, which over the early part of this decade saw real increases of $10-15 \%$ per year on top of inflation, will moderate. The cooling towers, scrubbers, and other new design requirements imposed on fossil units over the last decade have now come close to full incorporation in new designs, and costs should therefore stabilize somewhat. Cost per $\mathrm{kW}$ should rise primarily by the excess of utility inflation over base natural inflation--a matter of $2-3 \%$ per year. Nuclear ratcheting, while not yet over, should slowly moderate also, reducing the annual real 
TABLE 2

Annual capital expenditures, millions of dollars

(Adjustod to 100\% of utllity Industry. All higures in 1981 dollars)

$\begin{array}{lccccc} & \text { Generation } & \text { Transmission } & \text { Distribution } & \text { Miscellaneous } & \text { Total } \\ 1970 & 14,672 & 4,541 & 6,981 & 1,132 & 27,326 \\ 1971 & 17,455 & 4,430 & 7,483 & 1,461 & 30,829 \\ 1972 & 19,032 & 4,199 & 7,797 & 1.519 & 32,547 \\ 1973 & 20,207 & 4,532 & 8,201 & 1,693 & 34,633 \\ 1974 & 21,069 & 4,130 & 7,712 & 1,726 & 34,637 \\ 1975 & 19,561 & 3,657 & 6,257 & 1,508 & 30,983 \\ 1976 & 24,289 & 4,305 & 6,650 & 1,585 & 36,829 \\ 1977 & 26,383 & 4,291 & 6,251 & 1,365 & 38,290 \\ 1978 & 28,453 & 3,547 & 5,635 & 1,577 & 39,212 \\ 1979 & 29,554 & 4,020 & 6,332 & 1,584 & 41,490 \\ 1980 & 27,916 & 3,558 & 5,735 & 1,759 & 38,968 \\ & & & & & \end{array}$

\section{Forecast}

$\begin{array}{llllll}1981^{1} & 27,750 & 3,774 & 6,300 & 1,515 & 39,339 \\ 1982 & 28,150 & 3,940 & 6,640 & 1,550 & 40,280 \\ 1983 & 26,343 & 3,690 & 6,850 & 1,475 & 38,358 \\ 1984 & 21,500 & 3,100 & 7,200 & 1,275 & 33,075 \\ 1985 & 19,990 & 2,800 & 7,190 & 1,200 & 31,180 \\ 1986 & 16,006 & 2,425 & 7,000 & 1,015 & 26,446 \\ 1987 & 14,177 & 2,150 & 7,080 & 940 & 24,347 \\ 1988 & 15,786 & 2,360 & 7,275 & 1,025 & 26,446 \\ 1989 & 19,733 & 2,660 & 7,350 & 1,190 & 30,933 \\ 1990 & 25,096 & 3,315 & 7,460 & 1,435 & 37,306 \\ 1991 & 29,704 & 3,860 & 7,840 & 1,657 & 43,061 \\ 1992 & 33,989 & 4,415 & 7,795 & 1,850 & 48,049 \\ 1993 & 37,923 & 4,930 & 7,840 & 2,028 & 52,721 \\ 1994 & 45,597 & 5,925 & 7,970 & 2,380 & 61,872 \\ 1995 & 53,263 & 6,900 & 8,075 & 2,730 & 70,968 \\ 1996 & 56,652 & 7,350 & 8,490 & 2,900 & 75,392 \\ 1997 & 53,873 & 7,000 & 8,770 & 2,716 & 72,359 \\ 1998 & 51,483 & 6,690 & 9,100 & 2,624 & 69,897 \\ 1999 & 51,157 & 6,650 & 9,390 & 2,620 & 69,817 \\ 2000 & 50,193 & 6,525 & 9,400 & 2,314 & 68,432\end{array}$

Annual capital expenditures, 1981 dollars

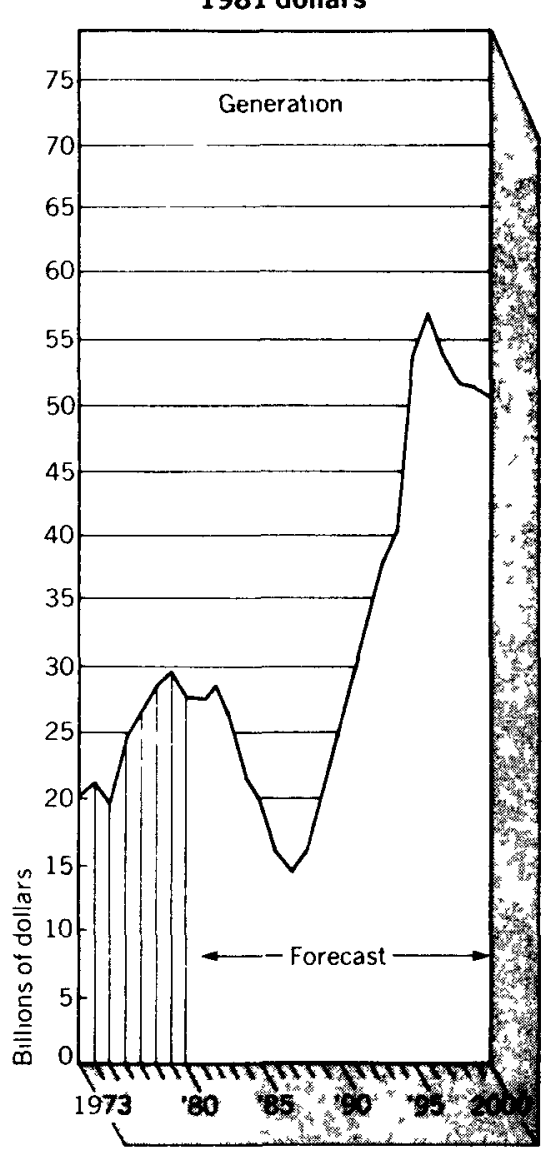


increase in per $\mathrm{kW}$ cost due to new regulations to a more manageable $4-5 \%$ over inflation.

"As utilities begin to get the rate of return they need to make their securities attractive at more reasonable interest, this additional inflation over that of other industrial construction should begin to decrease somewhat further.

\section{Capability}

"Each year, Electrical World becomes a revisionist, changing the value of peak demand upon which the previous year's forecast was built. This is simply because, at forecast time, not only is the current year's peak not yet available, but usually the previous year's peak has been revised by the systems involved. The figure (6.8\% peak growth as shown on Table 1) used in this year's (EW) forecast for the 1980 peak is a composite. The basis figure is the peak reported in the North American Electric Reliability Council (NERC) report, "Electric Power Supply \& Demand", issued in July. This figure does not include interruptible loads, and so is a true measure of peak that must be served. To this, (EW) added about 10 MW of load in the contiguous U.S. that does not appear in the NERC report because the systems involved do not report to that organization. Capability is similarly treated, with about 12.5 MW of capability added.

\section{$\underline{\text { Nuclear }}$}

"(EW's) philosophy of what will happen in the nuclear area continues to evolve. (EW's) latest thoughts are reflected in substantial increases in projected capacity additions in the very late 1990s (see Table 3 and Figure 1). 
TABLE 3

Generating capacity additions, MW (Based on date of commercial operation)

\begin{tabular}{|c|c|c|c|c|c|c|}
\hline & $\begin{array}{c}\text { Conventional } \\
\text { hydro }\end{array}$ & $\begin{array}{l}\text { Pumped } \\
\text { hydro }\end{array}$ & $\begin{array}{l}\text { Fossil } \\
\text { steam }\end{array}$ & $\begin{array}{l}\text { Nuclear } \\
\text { steam }\end{array}$ & $\begin{array}{c}\text { Combustion } \\
\text { turbine \& I.C. }\end{array}$ & Total \\
\hline 1970 & 1,789 & 313 & 16,800 & 2,513 & 6.126 & 27,541 \\
\hline 1971 & 624 & 219 & 17,564 & 2,194 & 5.705 & 26,306 \\
\hline 1972 & 382 & 286 & 18,455 & 6,613 & 6,474 & 32.210 \\
\hline 1973 & 1,594 & 3,622 & 24,217 & 5,770 & 5,066 & 40,269 \\
\hline 1974 & 720 & 1,087 & 18,874 & 9,196 & 6,236 & 36,113 \\
\hline 1975 & 2,064 & 305 & 21.726 & 7,281 & 3.524 & 34,900 \\
\hline 1976 & 300 & 235 & 11.908 & 4,457 & 2,600 & 19.500 \\
\hline 1977 & 1.438 & 485 & 16.509 & 6,530 & 1.647 & 26,609 \\
\hline 1978 & 4.265 & 841 & 14.454 & 2,162 & 2,213 & 23,935 \\
\hline 1979 & 2,632 & 1.200 & 10.999 & 1,874 & 370 & 17.075 \\
\hline $1980^{1}$ & 1.078 & 257 & 14,214 & 2,887 & 446 & 18,882 \\
\hline \multicolumn{7}{|c|}{ Forecast } \\
\hline 1981 & 494 & 131 & $8,123^{2}$ & 5,387 & 439 & 14,574 \\
\hline 1982 & 395 & 1.287 & 10,574 & 13,079 & 258 & 25,593 \\
\hline 1983 & 1,138 & 158 & 10,220 & 14,622 & 525 & 26,663 \\
\hline 1984 & 1,082 & 0 & 8,193 & 7,455 & 0 & 16,730 \\
\hline 1985 & 451 & 700 & 11,811 & 11,109 & 30 & 24,101 \\
\hline 1986 & 545 & 650 & 7.510 & 9,831 & 0 & 18.536 \\
\hline 1987 & 394 & 2.025 & 5.986 & 4.686 & 195 & 13.286 \\
\hline 1988 & 804 & 350 & 5.012 & 8.063 & 0 & 14,229 \\
\hline 1989 & 0 & 0 & 4,702 & 2.197 & 0 & 6,899 \\
\hline 1990 & 0 & 0 & 6.289 & 1.250 & 0 & 7.539 \\
\hline 1991 & 0 & 0 & 12,436 & 0 & 0 & 12,436 \\
\hline 1992 & 0 & 0 & 16.340 & 1.250 & 0 & 17.590 \\
\hline 1993 & 0 & 0 & 16.597 & 0 & 0 & 16.597 \\
\hline 1994 & 0 & 0 & 19,176 & 0 & 0 & 19.176 \\
\hline 1995 & 0 & 0 & 17.578 & 1.910 & 0 & 19.488 \\
\hline 1996 & 0 & 0 & 21,854 & 1.260 & 0 & 23,114 \\
\hline 1997 & 0 & 0 & 26,621 & 0 & 0 & 26.621 \\
\hline 1998 & 0 & 0 & 23,089 & 3,550 & 50 & 26,689 \\
\hline 1999 & 0 & 0 & 12,477 & 15,297 & 100 & 27,874 \\
\hline 2000 & 0 & 0 & 14.687 & 14,219 & 150 & 29,056 \\
\hline
\end{tabular}


FIGURE 1

Probable mix of net generating capacity

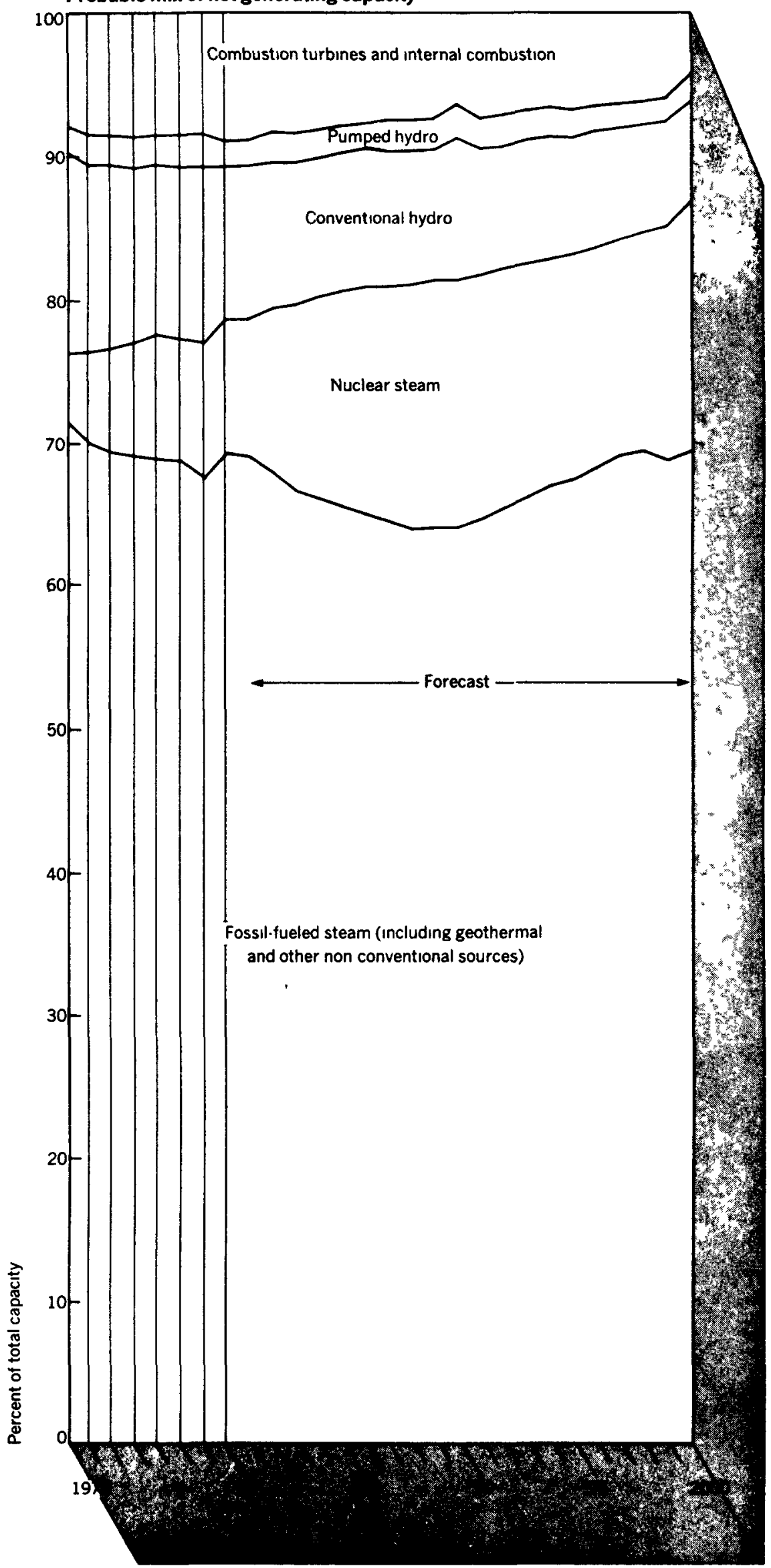

Electrited Wond, September 1981 
"(EN) feels that the utility industry will not have progressed far enough toward financial health to permit renewed consideration of nuclear power until about 1986. The considerable economic advantages of nuclear power have been effectively nullified by paralyzing inflation, regulatory uncertainty, and confiscatory rates of return. But these should moderate enough by 1986 or thereabouts to permit rational economic choices to be made once more.

"(EW's) expectation of increases in nuclear capacity additions late in the next decade come about because, while (EW) still foresees 1986-87 as the earliest date for the new orders, (EW) thinks overall lead time can be cut from the present ludicrous span of 14 years to a span of 10. This reduction should be made possible by a clearing away of regulatory impediments, by increasing standardization of units, and by elimination of today's financially induced delays in construction.

"The onset dates of 1986-1987 are of overwhelming importance, in (EW's) opinion. If new orders are not forthcoming by about then, the entire future of commercial power in this country will be blighted--perhaps permanently. By then, the present huge backlog will have been worked down almost completely, and the host of suppliers of thousands of sma11 but critical components who now hold the N-stamp will have disappeared. Engineering and operating personnel can be hired and trained in a relatively short time, but the time to reconstruct the supplier network that took two decades to build may be just too long. 


\section{Fossil}

"The continued downward revisions of load-growth estimates even while units are under construction means that some fossil units will be completed that are not strictly required by the measure of reserve capacity. And though we are showing some additional delays and cancellations again this year, they are proportionately fewer. Coupled with lower growth projections, this means that reserves will not fall as rapidly as we had previously projected. This is by no means a negative development, however. The high reserves in the Northeast, for example, will permit blocks of oil-fired capacity to be held out of service. And should load growth strengthen--as is entirely possible--response time is cut from normal new-construction lead-time to the time required to reactivate 'excess' units held in cold shutdown.

"Again this year, (EW) has not made any appreciable adjustments in the capacity-additions schedule for the possible effects of the Fuel Use Act's proscription of the use of gas as a boiler fuel after 1990, because (EW) still assumes that it will be revised to eliminate the off-gas provision. (EW) has allowed for a somewhat accelerated retirement schedule of gas-fired units, however, but only because (EW) expects gas to be deregulated under this Administration more quickly than had previously been planned. This will alter the economics of fuel supply as its full impact phases in, making gas less attractive as fuel. 
"Implicit in the determination of the cost of new units is the belief that they will be coal-fired, and will have scrubbers and cooling towers, or the equivalent. Should the Administration succeed in modifying the emissions standard for units using low-sulfur coal, costs could decrease noticeably.

Hydro

"Several large hydro installations are still scheduled for completion within the next decade. Total capacity to be installed is almost even1y split between conventional hydro and pumped storage. Considerable activity is under way or planned for small hydro, and such units are included in our total for the next five years. Beyond that, however, the future of many of these units depends on determination of "avoided costs" that must be paid by utilities to developers of small hydro sites who channel their output into the utility grid. This is slated to be a hotly contested issue, and will be determined on a state-by-state basis. In any case, the total amount will be relatively minor compared to other capacity, so we do not project beyond 1988." 
II. ENERGY AND FUELS

\section{A. U.S. Electric Utility Statistics}

For the 52 week period ending December 26, 1981, the Edison Electric Institute (EEI) reported a total of $2,313,477$ million net kilowatthours (kWh) distributed by the electric utility industry in the 48 contiguous states.

This represents an increase of 0.5 percent over the total net Kwh for the corresponding period a year earlier. It compares with corresponding changes reported in past issues of UPDATE as follows:

\section{$\frac{\text { Electrical Energy Output in United States }}{(48 \text { States })}$}

52 Weeks

Ended

January 31

February 28

March 28

May 2

May 30

June 25

August 1

August 29

October 3

October 31

November 28

December 26
1981

(million $\mathrm{kWh}$ )

$2,309,188$

$2,309,415$

$2,306,117$

$2,309,649$

$2,313,336$

$2,328,273$

$2,326,511$

$2,321,025$

$2,315,637$.

$2,317,246$

$2,313,568$

$2,313,477$
Change

$81 / 80$

(percent)

$+2.4$

$+2.4$

$+2.1$

$+2.3$

$+2.6$

$+2.6$

$+2.5$

$+1.7$

$+1.0$

$+1.1$

$+0.8$

$+0.5$

For the 52 weeks of 1981 , the EEI reports a total output of 2,313,477 million net kilowatt-hours, which represents a 0.5 percent increase over the $2,300,955$ million net kilowatt-hours produced in the corresponding period in 1980 . 
Recently published EEI statistics $1 /$ relating to classifications of energy sales by all U.S. utilities (public, privately-owned and cooperative) in the 50 states, for the 12 months ended September 30, 1981, show the commercial and industrial sectors jointly consuming 1.9 percent more than for the previous 12 month period. Sales to the residential community increased by 0.5 percent. Overall during the period, total energy sales to ultimate customers averaged 1.5 percent higher for the twelve months ended September 30, 1981. A complete breakdown of these sales to ultimate consumers is presented as follows:

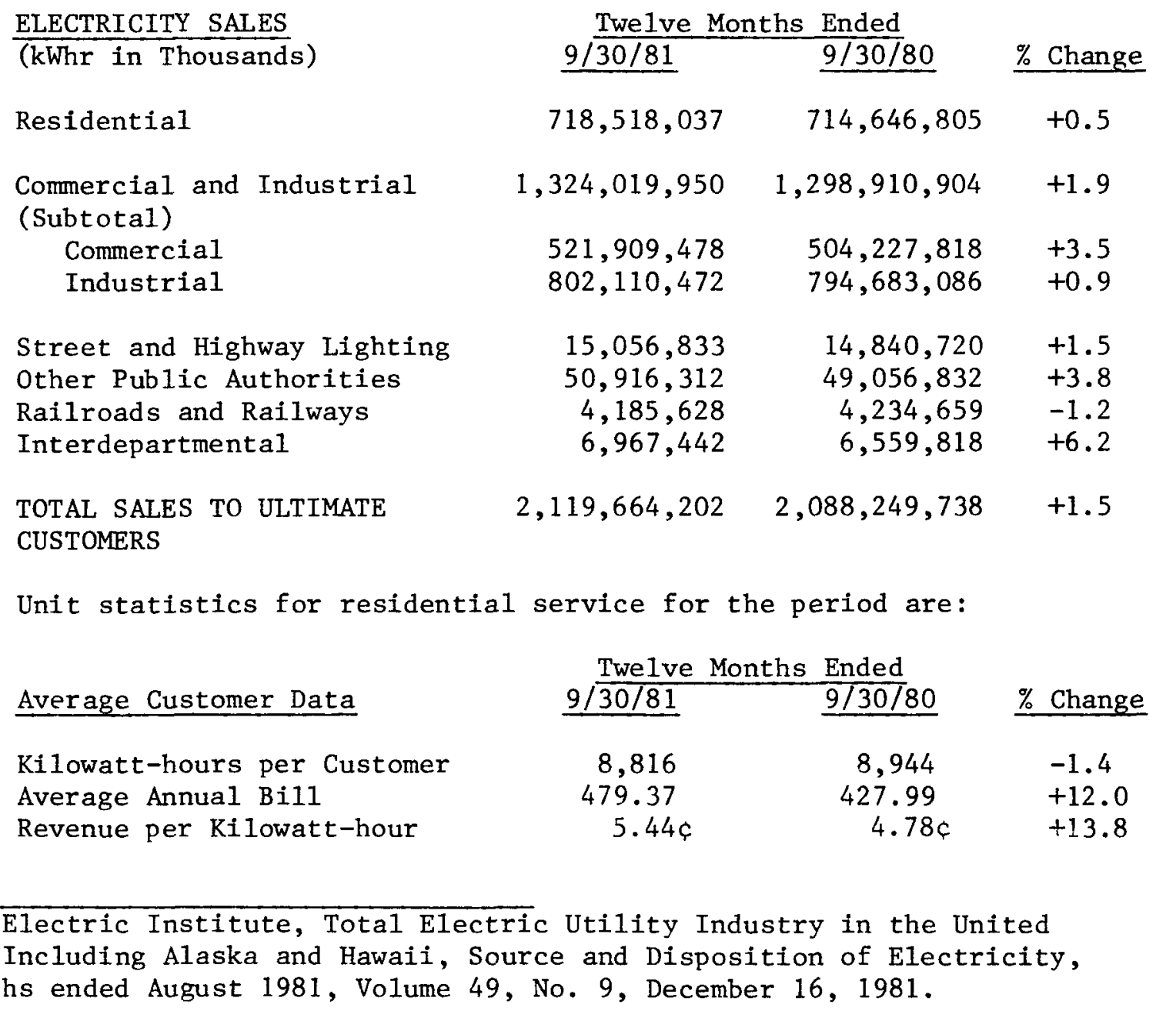


EEI financial data indicate that revenue from ultimate customers of the electric utility industry totaled $\$ 102,647$ million for the twelve months ending September $30,1981,16.7$ percent above the figure for the corresponding period one year earlier. 


\section{B. Spent Fuel and Radioactive Waste}

A recent report prepared at the Oak Ridge Nationa1 Laboratory addressed December 31, 1980 inventories of spent fuel and radioactive waste and made projections of future inventories. 1 / Estimated future waste generation was based on expected defenserelated, industrial, and institutional activities and a contemporary DOE/EIA projection of U.S. commercial nuclear power growth. The report considered spent fuel, high-level waste, transuranic waste, low-level waste, active uranium mill tailings, remedial action waste, and airborne waste. Actual and projected inventories were presented by category through the year 2000; this information is summarized in Table 1. The land usage requirements were given for storage/disposal of low-level and transuranic wastes, and the present inventories of tailings of inactive uranium mills.

\section{Spent Fue1}

The projected inventories of commercial spent fuel were based on the EIA mid-growth forecast. This forecast has the 1980 installed U.S. nuclear capacity nearly doubling from $53.8 \mathrm{GW}(\mathrm{e})$ to $103.6 \mathrm{GW}(\mathrm{e})$ by the end of 1985, and reaching $179.7 \mathrm{GW}(\mathrm{e})$ by the end of 2000 . No spent fuel reprocessing is assumed (once-through fuel cycle). Reprocessing would greatly reduce spent fuel inventories.

1/ Spent Fuel and Radioactive Waste Inventories and Projections as of December 31, 1980, Department of Energy publication DOE/NE-0017 (September, 1981). 
Table 1

Projected Inventories of Radioactive Wastes

\begin{tabular}{ccc}
\multirow{2}{*}{$\begin{array}{c}\text { End of } \\
\text { Calendar Year }\end{array}$} & MTU Uranium & $\begin{array}{c}\text { Radioactivity } \\
\text { (MCi) }\end{array}$ \\
\cline { 3 - 3 } 1980 & 6,700 & 10,400 \\
1985 & 15,800 & 21,000 \\
1990 & 32,000 & 35,000 \\
1995 & 50,000 & 47,000 \\
2000 & 72,000 & 55,000
\end{tabular}

\begin{tabular}{cc} 
High-Level Waste (HLW) \\
$\begin{array}{c}\text { Volume } \\
\left(10^{3} \mathrm{~m}^{3}\right)\end{array}$ & $\begin{array}{c}\text { Radioactivity } \\
\text { (MCi) }\end{array}$ \\
\hline
\end{tabular}

293

308

320

323

337
1,347

1,384

1,797

1,656

1,643

\section{Transuranic Waste (TRU) Volume TRU $\left(10^{3} \mathrm{~m}^{3}\right) \quad$ Elements $(\mathrm{kg})$} 1,940

361

2,390

382

3,130

400

3,850

420

\section{Definitions :}

Spent Fuel is irradiated fuel discharged from a commercial or special experimental research reactor.

High Level Waste (HLW) originates in reprocessing spent fuel and discharged defense production reactor fuel and is the aqueous waste from the first cycle extraction system, or equivalent concentrated waste from subsequent extraction cycles, or equivalent waste from a process not using solvent extraction in a facility for processing irradiated fuels. HLW may also be in the form of sludge, calcine, or other products generated in treating liquid HLW.

Transuranic Waste (TRW), as defined by DOE, is material, excluding HLW, that is contaminated with certain alpha-emitting radionuclides of long-life and high specific radiotoxicity to a level greater than 10 nanocuries per gram.

MTU - metric tons uranium

$\underline{M C i}$ - megacurie 
Table 1 (Cont'd.)

\begin{tabular}{ccc}
$\begin{array}{c}\text { End of } \\
\text { Calendar Year }\end{array}$ & \multicolumn{2}{c}{ Low-Leve1 Waste (LLW) } \\
\hline 1980 & $\frac{762}{\left(10^{3} \mathrm{~m} 3\right)}$ & $\begin{array}{c}\text { DOE Volume } \\
\left(10^{3} \mathrm{~m}^{3}\right)\end{array}$ \\
1985 & 1,334 & 1,528 \\
1990 & 2,172 & 1,932 \\
1995 & 3,155 & 2,332 \\
2000 & 4,280 & 2,732 \\
& & 3,132
\end{tabular}

\begin{tabular}{cc}
\multicolumn{2}{c}{ Active Mill Tailings } \\
$\begin{array}{c}\text { Volume } \\
\left(10^{3} \mathrm{~m}^{3}\right)\end{array}$ & $\begin{array}{c}\text { Radioactivity } \\
\text { (MCi) }\end{array}$ \\
& 0.892 \\
145,000 & 1.250 \\
197,000 & 1.660 \\
258,000 & 2.110 \\
333,000 & 2.660
\end{tabular}

Definitions:

Low Level Waste (LLW) means radioactive waste not classified as HLW, TRU, spent fuel or byproduct material. It is contaminated material that contains low, but potentially hazardous amounts of radionuclides.

Active Mill Tailings (Uranium Mill Tailings) are the earthen residues that remain after the extraction of uranium from ores. Tailings are generated in very large volumes and contain very low concentrations of naturally occurring radioactive materials. Active mill tailings are those tailings that exist at operating sites and those that will be produced to fulfill future uranium requirements by operation of existing mills or newly developed milling sites. Tailings that exist at inactive sites are classified as "inactive mill tailings." 


\section{High-Leve1 Waste}

The projected inventories of high-level waste (HLW) were based on continuation of present volume-reduction programs for defense HLW at DOE sites. Commercial HLW was assumed to remain at the present volume of about $2,200 \mathrm{~m}^{3}$ since no schedule exists for reprocessing commercial spent fuel.

\section{Transuranic Waste}

Prior to 1970 , waste disposal procedures did not require segregation of transuranic (TRU) waste from low-1evel waste. About $270,000 \mathrm{~m}^{3}$ of low-level waste containing about $1000 \mathrm{~kg}$ of TRU elements were buried in eight DOE sites. About $419,000 \mathrm{~m}^{3}$ were buried at five commercial sites but the TRU quantity is unknown. Since 1970, TRU waste has been placed in retrievable storage. TRU waste projections assumed continued retrievable storage and no volume compaction except for the waste generated at Los Alamos National Laboratory.

\section{Low-Leve1 Waste}

Low-level waste (LLW) is generated by commercial and institutional activities and buried at commercial sites. LLW generated by federal activities is buried at DOE sites. The accumulated activity levels, uncorrected for decay, were $26.7 \mathrm{MCi}$ at DOE sites and $6.3 \mathrm{MCi}$ at commercial sites by the end of 1980. Non-DOE LLW was projected to add 1.8 MCi in 1981 increasing to $3.7 \mathrm{MCi}$ in 2000. DOE LLW activity additions were not given. An additional 266 hectares (159 commercial, 107 DOE) was the projected land requirement through the end of the century. 


\section{Remedial Action Waste}

Remedial action wastes are generated under four programs. The Uranium Mill Tailings Remedial Action Program (UMTRAP) deals with inactive uranium mill tailings. UMTRAP will treat about 14.7 million cubic meters of tailings and 4.2 million cubic meters of other materials, mostly contaminated soil. Depending upon sitespecific factors, UMTRAP wastes will be stabilized on-site or removed to another location and stabilized. The Formerly Utilized Sites Remedial Action Program (FUSRAP) is intended to restore certain identified sites to as near as practicable to unrestricted uses. Thirty-one sites in 13 states have been identified as potential candidates. FUSRAP is estimated to involve approximately $452,000 \mathrm{~m}^{3}$ of LLW. The Surplus Facilities Management Program (SFMP) is intended to restore approximately 500 DOE facilities. Until its scheduled year 2000 completion, SFMP will generate an estimated $1,554,000 \mathrm{~m}^{3}$ of LLW and $8,890 \mathrm{~m}^{3}$ of TRU waste. The Grand Junction Remedial Action Project (GJRAP) began in 1973 and involves the rehabilitation of approximately 740 structures. By the end of 1980, 394 structures were finished or in progress and $45,900 \mathrm{~m}^{3}$ of LLW had been generated.

\section{Active Mill Tailings}

At the end of 1980, there were 22 operating uranium mills. The projected active mill tailings included only those tailings produced to meet the projected needs of the commercial fuel cycle. No allowances were made for uranium import/export, for "unconventional" 
production (e.g., by-product recovery or in situ mining), or for government/defense requirements.

\section{Airborne Waste}

Since airborne waste has traditionally been released to the atmosphere under carefully controlled conditions at both DOE and commercial nuclear facilities, there is none presently in inventory except that contained in spent fuel. Each year DOE facilities typically release about $1.07 \mathrm{MCi}$. Releases from operating reactors are very small. New regulations require the separation and recovery of certain isotopes and these requirements may eventually be extended to other isotopes as well. 


\section{NCA Revised Coal Forecast for 1981}

As reported in the September 28, 1981 issue of Coal News, the National Coal Association (NCA) forecasts a record consumption of U.S. coa1 in 1981 of 838 million tons, an increase of 6.2 percent over the 789 million tons for 1980. Total domestic consumption in 1981 is expected to reach 744 million tons, a 6.4 percent increase over the 699 million tons for 1980. A breakdown of these figures by area and market is given in Table 1.

Coal production for 1981 should reach 795 million tons; this is less than predicted earlier in the year and is primarily due to the 72-day miners' strike. The difference between consumption and production is being met by a net 42 million-ton reduction in inventories, mostly at electric utilities in the eastern United States.

NCA forecasts coal use by utilities to reach a record 600 million tons this year, up 5.6 percent from the 568 million for 1980 . Electric generation by coal-fired plants is forecasted to climb to a 52.4 percent share by the end of the year, reflecting the continued displacement of high-cost oil by coal.

Exports of U.S. coal continue to increase, with total exports expected to reach 94 million tons for the year, with steam coal accounting for 40 million of that total. Last year, overseas steam coal exports were 16 million tons and and in 1979 the figure was 2.5 million. 
Table 1

NCA Revised 1981 Coal Production Forecast

U.S. Annual Coal Production and Consumption

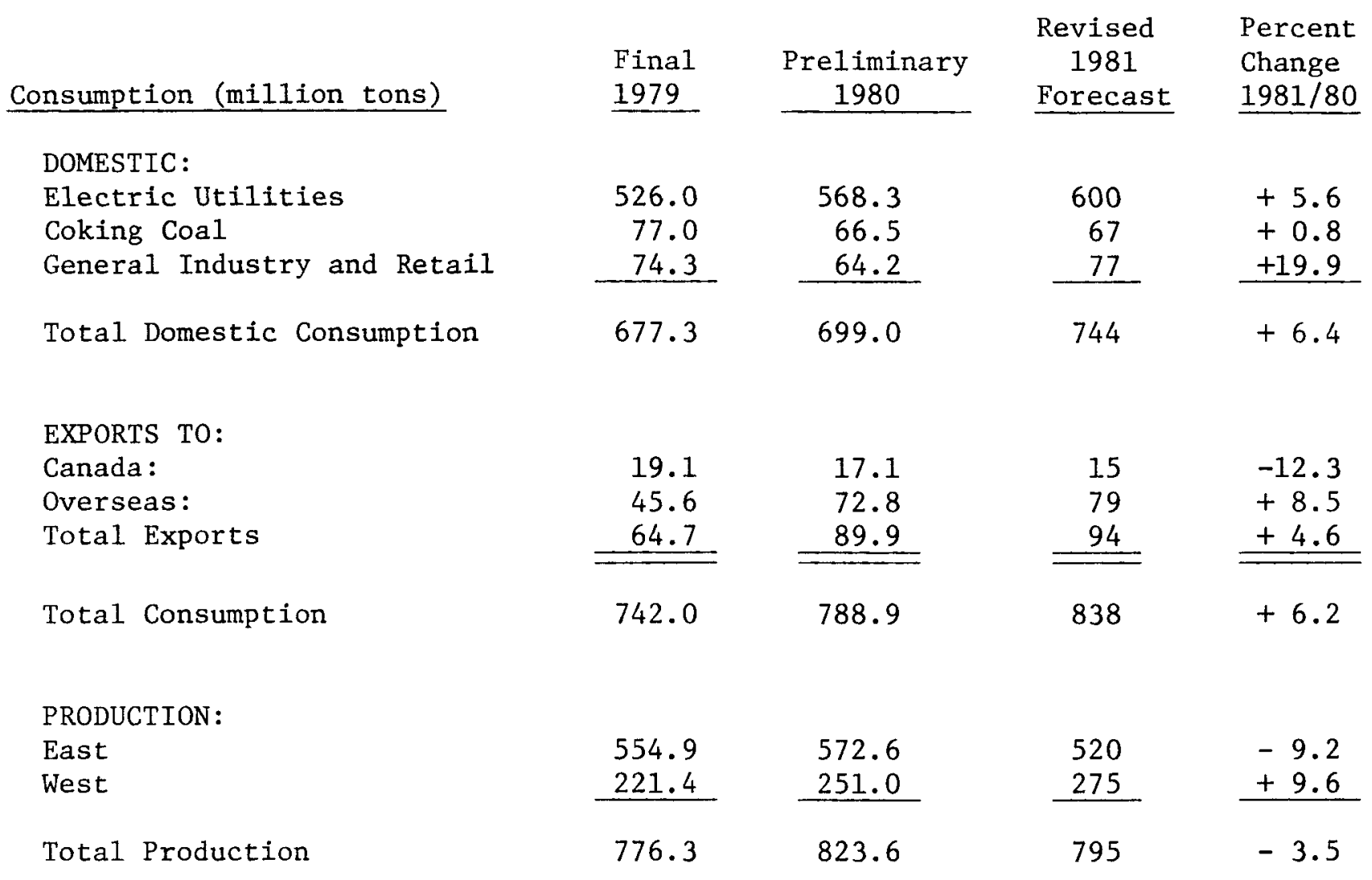


III. ECONOMICS

A. Analysis of Utility Reports on Nuclear Power Plant Capital Costs The majority of U.S. electric utilities with nuclear power plants under construction and/or on order provide estimated project schedules and capital costs for these units every three months to the Department of Energy. Presented below is an updated analysis by United Engineers

\& Constructors Inc. of nuclear unit capital costs reported as of June 30 , 1981, including examination of the effects of time of entry into service, size, and geographical location.

The Department of Energy requests the utilities to report their capital cost estimates on an "as disbursed" (current dollar) basis, including direct costs, indirect costs, escalation, and where applicable, allowance for funds used during construction (AFUDC). The costs for nuclear fuel, transmission switchyard, and training of personnel are not included in the plant cost estimates. The unit costs of like units in a multi-unit station are determined by dividing the total of the costs of those units coming into service within a year or two of each other by the sum of the net electrical kilowatt (kWe) ratings of the units. The cost of each unit is then included in the sample corresponding to its year of initial commercial operation.

The costs included in the data base for this analysis have been reviewed and, where necessary, updated by the utilities since the previous analysis, which was based on reports as of December 31, 1980. Data not reviewed and/or updated have been excluded from the analysis. Also, a few utilities did not submit the requested returns. Nonetheless, sufficient recent data ( $n=65$ units) have been submitted 
to show reasonably good capital cost levels and trends for nuclear power plants coming on-line in the next ten years.

The results of this analysis are not intended for use in determining whether or not the costs of a particular plant are high or low; the differences in regional conditions and construction schedule lengths, in individual plant characteristics--a number of which are site related--and in the tax and financing situations of individual electric utilities can result in appreciable variations in individual plant costs from the cost averages in the analysis. It should also be noted that this analysis reflects schedules and costs reported by the utilities; it is not a DOE projection.

\section{Cost Variation with Time}

In Table 1 appear the averages (weighted by plant size) of light water reactor (LWR) unit capital costs of generating units entering commercial service each year, by size category and in the aggregate, for the years 1981 through 1991. This information is presented graphically in Figure 1 for all units (solid line) and also for sizes 1000 MWe and larger (dashed line).

Examination of Figure 1 reveals a fairly steady annual rise in the average capital cost over the period 1981-1991. A linear least-squares trend line for all units shows an average annual increase in unit costs of $\$ 142$ per kilowatt-electric (kWe). The rate of increase represented by this trend line is $9.1 \%$. $1 /$

1/ Due to the use of a revised least-squares calculation procedure, the annual rate of increase is less than reported in previous analyses (March/April 1980 UPDATE, page 54). 
TABLE 1

Average U.S. LWR Power Plant Unit Capital Costs (as of June 30, 1981)

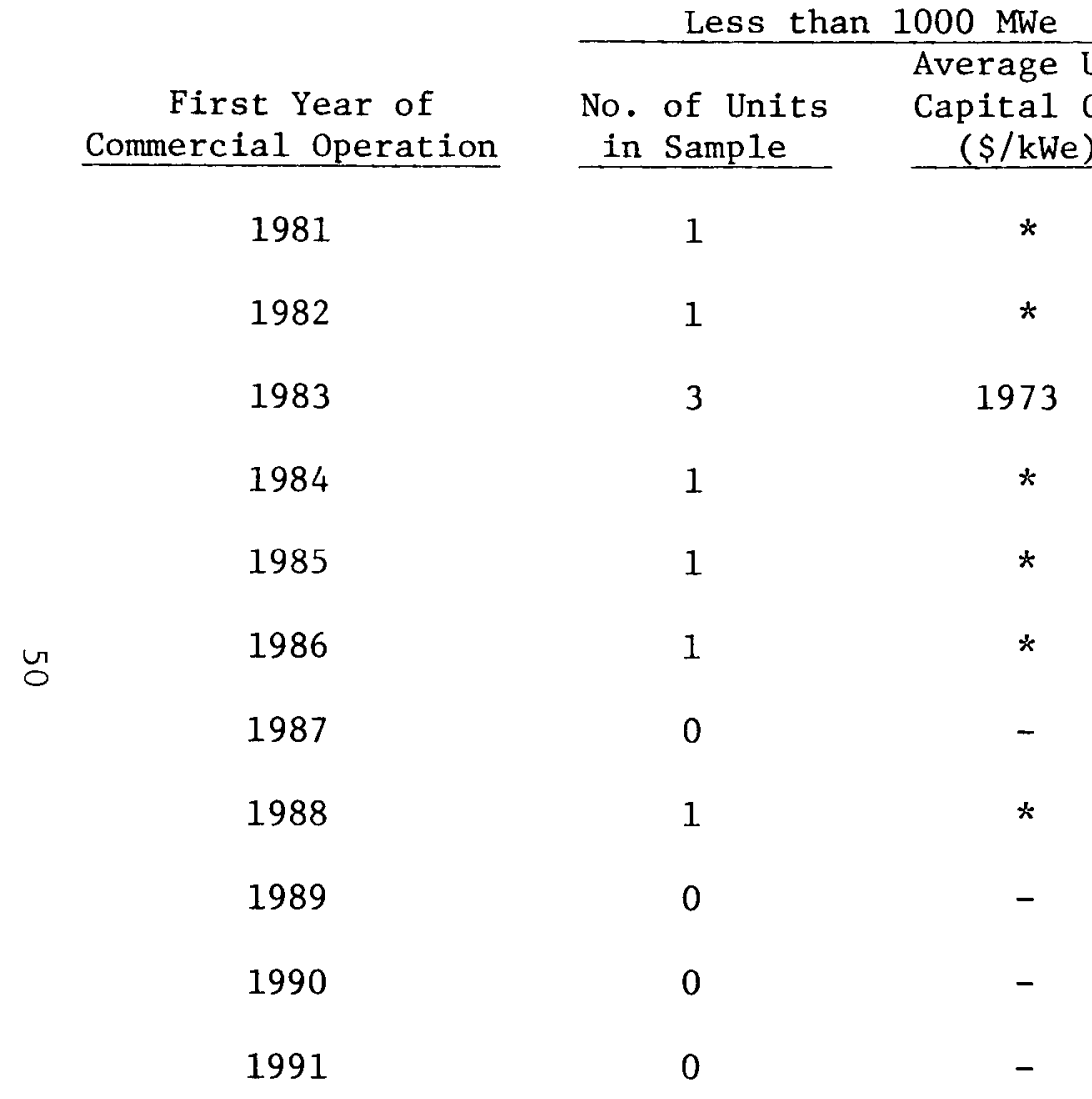

$\frac{1000 \text { SWe and Up }}{\text { No. of Units } \begin{array}{l}\text { Average Unit } \\ \text { Capital Cost }\end{array}}$
in Sample

3 $(\$ / \mathrm{kWe})$

905

1,081

1,264

1,314

1,380

1,743

1,565

2,073

2,092

$-$

2,509
Al1 Units

Average Unit No. of Units Capital Cost in Sample ( $\quad$ /kWe

4

923

6

1,112

12

1,441

13

1,400

6

1,452

1,833

1,565

2,029

2,092

0

2

2,509 
AVERAGE LWR POWER PLANT UNIT CAPITAL COSTS

BY YEAR OF ENTRY INTO SERVICE (REPORTED AS OF JUNE 30, 1981)

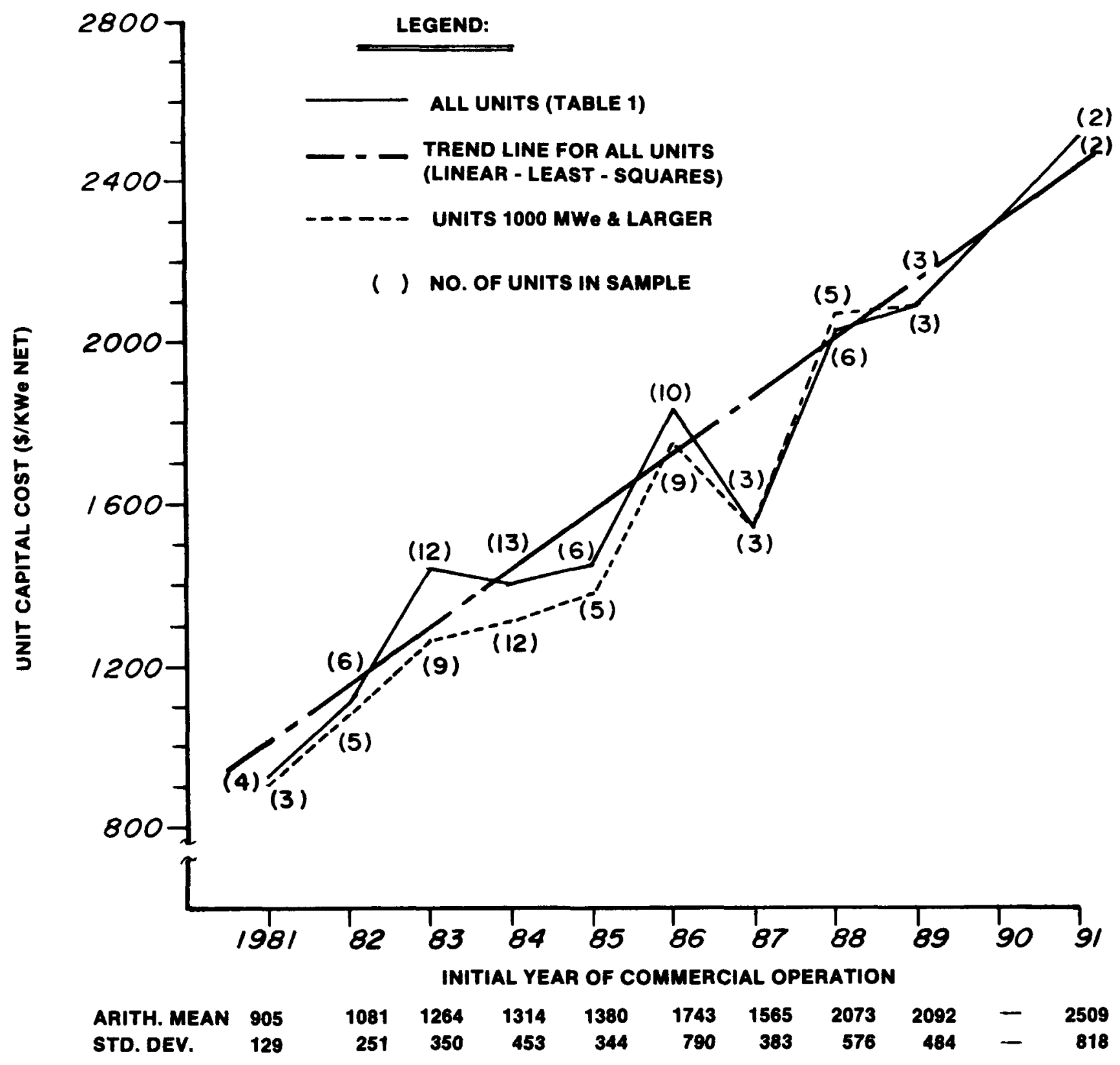

UNIT CAPITAL COST VALUES FOR 1000 MWO AND LARGER UNITS: 
The spread in the unit costs of individual units in the same size category for each year is large--at times more than two to one. For an appreciation of this variation, the arithmetic mean and the standard deviation of the unit cost values of units 1000 MWe and larger are shown for each year in Figure 1. A principal reason for variation is region location, which is discussed below. Other contributing factors are differences in site conditions (affecting seismic, containment and cooling water requirements, for instance), engineering and construction arrangements, labor costs, financing costs, taxes, and assumptions regarding future price escalation.

\section{Cost Variation with Size}

On balance, there is evidence of economy of scale in the average unit costs shown in Table 1 and in the plots of Figure 1. With the exception of 1988 , in all years where a comparison can be made the average unit costs of the units rated 1000 MWe and larger are lower than the concurrent costs for the units in the under 1000 MWe category. The opportunity for annual comparison is limited, however, by the relative paucity of smaller units coming on-line each year in the U.S. Furthermore, the unit costs correspond to plants located in different areas of the country and subject to different site and construction conditions. Evidence of economy of scale is more convincing where the average unit costs of the two size categories are compared within a particular region, as reported later in this analysis. 
Cost Variation By Region

Average unit capital costs by U.S. region for all units are shown in Table 2. These averages are weighted according to unit size. The states in each region are listed in Table 2.

As shown in column 3 of Table 2, the highest average unit cost occurs in the Northeast, followed in turn by the Middle Atlantic and Far West regional costs. Lower costs are reported for the West South Central and West North Central parts of the country, with the lowest costs occurring in the East South Central, East North Central, and South Atlantic regions.

The foregoing comparison takes no account of when the various units enter into service, which can affect the ranking of average regional costs. Comparison of average regional costs with concurrent national average costs affords a means of determining regional ranking where time of entry into service is taken into account. The results are shown in the rest of Table 2 and in Figure 2, explained as follows.

The averages of dates of entry into service of the units in each region are indicated in column 4 of Table 2 . These dates can be considered as temporal centroids (installed kilowatt weighted time average) of the respective regions. The national costs are interpolated from the least squares fit in Figure 1 and the corresponding averages of service entry dates. The average unit capital cost of each region is compared to the concurrent national average cost, and the ratio of the two shown in column 6 of Table 2 . 
TABLE 2

Ranking of LWR Power Plant Capital Costs by Region* (as of June 30,1981 )
(1)

\section{$\underline{\text { Region** }}$}

Northeast

Middle Atlantic

South Atlantic

East North Central

West North Central

East South Central

I West South Centra1

Far West
(2)

(3)

(4)

(5)

(6)

National Average Unit Average Regiona1

Number of Units in

Sample

\section{Unit Capital Cost}

$\$ / \mathrm{kWe}$

(A)

\section{2,177}

2,142

1,221

1,361

1,405

1,391

1,430

1,719

\begin{abstract}
Average of Dates of Entry into Service

of Units (mo/yr)
\end{abstract} (B)

\section{$6 / 85$}

$5 / 86$

$1 / 85$

$1 / 85$

$10 / 83$

$11 / 85$

i/85

$2 / 85$
Capital Cost at Time Shown in $B$ $\$ / \mathrm{kWe}$ (C)

1,673
1,790
1,600
1,600
1,421
1,718
1,600
1,611

Ranking (lowest cost to highest)

1.30

1.20

0.76

0.85

0.99

0.81

0.89

1.07

8
7
1
3
5
2
4
6

* For LWR units entering commercial service over the period 1979-1989.

**Northeast:

Middle Atlantic:

South Atlantic:

East North Centra1: West North Central:

East South Central: West South Central:

Far West:
New York and New England States

Pennsylvania, New Jersey, Maryland and Delaware

Virginia, North and South Carolina, Georgia, Florida

Ohio, Indiana, Michigan, Illinois, Wisconsin, Kentucky and West Virginia

Minnesota, Iowa, Nebraska, Kansas, Missouri, North and South Dakota

Tennessee, Alabama, Mississippi

Texas, Louisiana, Arkansas, Oklahoma

Mountain and Pacific States 
FIGURE 2

\section{REGIONAL LWR POWER PLANT CAPITAL COSTS COMPARED TO CONCURRENT NATIONAL LWR CAPITAL COSTS}

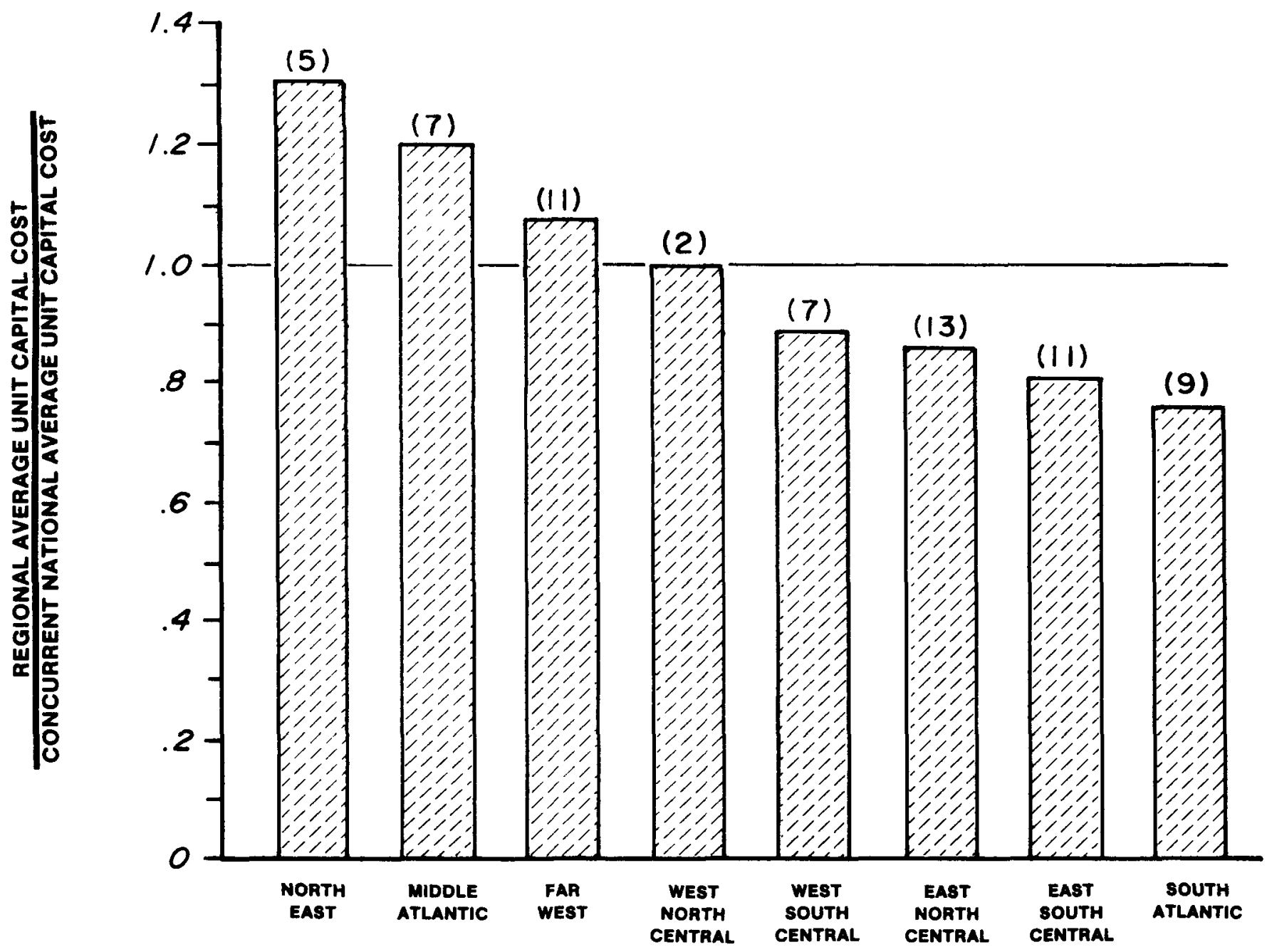

U.S. REGION

() - Number of units sampled. 
Measured against concurrent national cost levels, the Northeast region can then be said to experience the highest capital costs for its nuclear generating units, with the Middle Atlantic and Far West regions following. These are followed in order by the West North Central, West South Central, East North Central, and East South Central regions. Finally, with the lowest unit capital costs is the South Atlantic region.

The average unit cost rankings of the regions as determined by this method are shown in the last column of Table 2. Where time of entry into service is taken into account, then, the change in the rankings from those apparent in column 3 of Table 2 includes reversals of the East North Central and the East South Central regions, as well as the West North Central and the West South Central regions. Lower costs in the southern areas of the country are not unexpected. They reflect lower labor costs, less construction time lost due to inclement weather, and probably less weatherizing of buildings.

\section{Economy of Scale Within a Region}

Only in the South Atlantic and East North Central regions is there more than one unit of less than 1000 MWe in size. Although only two and three such units are included in these regions, they afford some idea of the economy of scale of nuclear power plants. 
As shown in Table 3, the unit costs of the larger power plants are less than those of the smaller size plants. In the East North Central region, the larger plants have a unit capital cost that is $\$ 297$ per kilowatt lower than the smaller plants despite the fact that the larger units enter service 27 months later on the average and are, therefore, subject to greater price escalation. In the South Atlantic region, the larger units have a cost that is $\$ 624$ per kilowatt lower. Although these larger units enter service 13 months earlier on the average, price escalation over this interval could not be expected to totally account for this large differential.

TABLE 3

LWR Power Plant Unit Capital Costs by Size and Region (as of June 30,1981 )

Region $\begin{aligned} & \text { Size } \\ & \text { Category }\end{aligned}$

South Atlantic

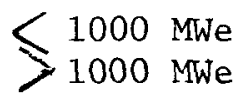

East North Centra1

$\leqslant 1000 \mathrm{MWe}$ 1000 MWe
2

11
No. of Units

in Sample

3

6

870

1,145

872

1,127

\begin{tabular}{l} 
Average Unit \\
Capita1 Cost \\
$(\$ / \mathrm{kWe})$ \\
\hline
\end{tabular}

1,687

1,063

$10 / 85$

$9 / 84$ of Entry

into Service (mo/yr) 


\section{B. Nuclear Versus Fossil Cost Post TMI}

In a presentation to the American Nuclear Society's 27th Annual Meeting, D. J. Kettler of Ebasco Services, Inc., analyzed the costs of nuclear and fossil power plants in a post-TMI environment. 1 / Mr. Kettler finds that when the TMI related costs due to new NRC requirements have been figured into the nuclear plant investment estimates, the nuclear plant has a "bus bar" energy cost that is about 11.5 percent lower than that of a coal plant using eastern coal and about 2.7 percent lower than that of a coal plant using western coal based on mid-1980 economic assumptions and estimates.

The study is an economic comparison that includes estimates of capital investment, fuel, operations and maintenance, and decommissioning costs. The generating plants considered are two $630 \mathrm{MW}$ (net) eastern high sulfur pulverized coal-fired units, two $630 \mathrm{MW}$ (net) western low sulfur pulverized coal-fired units, and one $1260 \mathrm{MW}$ (net) nuclear unit. Two $630 \mathrm{MW}$ coal units were used rather than one $1260 \mathrm{MW}$ unit as this is more typical of current industry trends.

The nuclear unit's commercial operation date is assumed to be January 1992 based on a mid-1980 authorization to proceed and a schedule duration of almost 12 years. The coal plants require 8 to 9 years lead time. However, for comparative purposes, it is assumed that the operating dates of the two coal units are July 1990 for Unit 1 and January 1992 for Unit 2.

I/ D. J. Kettler, "Nuclear Versus Fossil Cost Post TMI", American Nuclear Society - 27th Annual Meeting, June 7-11, 1981. 
The economic parameters are provided in Table 1. Plant capital costs are levelized over a 30-year period while fuel and O\&M costs are levelized over a 10-year period due to the uncertainties in projecting beyond this timeframe. Table 2 lists the technical data associated with each plant.

\section{Plant Investment}

Figure 1 shows the order-of-magnitude plant investment estimates for the three plant types. The base nuclear plant estimate does not include the cost of additional design changes resulting from the TMI accident. The estimates reflect all regulations existing as of June 1980 as well as average U.S. wage rates and field 1abor productivity. Land, substation, $T \& D$, and owner's costs are not included. The cost of the two eastern coal-fired plants is $\$ 1,537 / \mathrm{kW}$, including $\$ 631 / \mathrm{kW}$ for escalation and $\$ 260 / \mathrm{kW}$ for AFUDC. The western coal-fired plants cost $\$ 1,645 / \mathrm{kW}$, including escalation of $\$ 675 / \mathrm{kW}$ and $\$ 278 / \mathrm{kW}$ for AFUDC. The difference is a function of coal characteristics such as heat value, ash content, etc. The $1260 \mathrm{MW}$ nuclear plant has a cost of $\$ 2,557 / \mathrm{kW}$, including $\$ 841 / \mathrm{kW}$ of escalation and $\$ 737 / \mathrm{kW}$ for AFUDC. To account for future uncertainties, the estimates also include a $14 \%$ contingency for the coal units and a $17 \%$ contingency for the nuclear unit.

Impact of TMI

Due to new NRC requirements, the TMI accident will increase the $\$ 2,557 / \mathrm{kW}$ base nuclear plant estimate. The full extent of these requirements are not known; however, both the NRC and the Atomic 


\section{ECONOMIC PARAMETERS}

PLANT ECONOMIC LIFE

- YEARS

UTILITY RATE OF RETURN

$-\%$

14.0

LEVELIZED FIXED CHARGE RATE - $\%$

- NUCLEAR PLANT

18.4

- coal plant

18.1

AFDC RATE

$-\%$

9.5

CAPITAL COST ESCALATION RATE

$-\%$

- 1980

- 1981

- 1982 AND THEREAFTER

GNP IMPLICIT PRICE DEFLATOR*

$-\%$

- $1980-1985$

- $1986-1990$

- 1991 AND THEREAFTER

- COMPOSITE (1980 - 2000)

- BASIS FOR fUEL AND O\&M ESCALATION RATES

TABLE 2

\section{TECHNICAL PARAMETERS}

\begin{tabular}{|c|c|c|c|}
\hline & NUCLEAR & $\begin{array}{c}\text { EASTERN } \\
\text { COAL } \\
\end{array}$ & $\begin{array}{c}\text { WESTERN } \\
\text { COAL } \\
\end{array}$ \\
\hline \multicolumn{4}{|l|}{ NO. UNITS X MAXIMUM NET } \\
\hline RATING - MW & $1 \times 1,260$ & $2 \times 630$ & $2 \times 630$ \\
\hline \multicolumn{4}{|l|}{ PERFORMANCE } \\
\hline PARAMETERS & & & \\
\hline - SCHEDULED OUTAGE RATE & 16.0 & 11.5 & 11.5 \\
\hline - FORCED OUTAGE RATE & 12.0 & 11.5 & 11.5 \\
\hline - CAPACITY FACTOR & 65.0 & 65.0 & 65.0 \\
\hline
\end{tabular}

NET STATION HEAT RATE*

- BTU/kWhr

- DESIGN $(100 \%)$ LOAD

10,400

9,500

10,000

- anNual average

10,600

9,800

10,300

\footnotetext{
- BASED ON EBASCO REFERENCE PLANT DESIGNS.
} 
FIGURE 1

\section{COMPARATIVE PLANT INVESTMENT COSTS \\ 1980 Estimate}

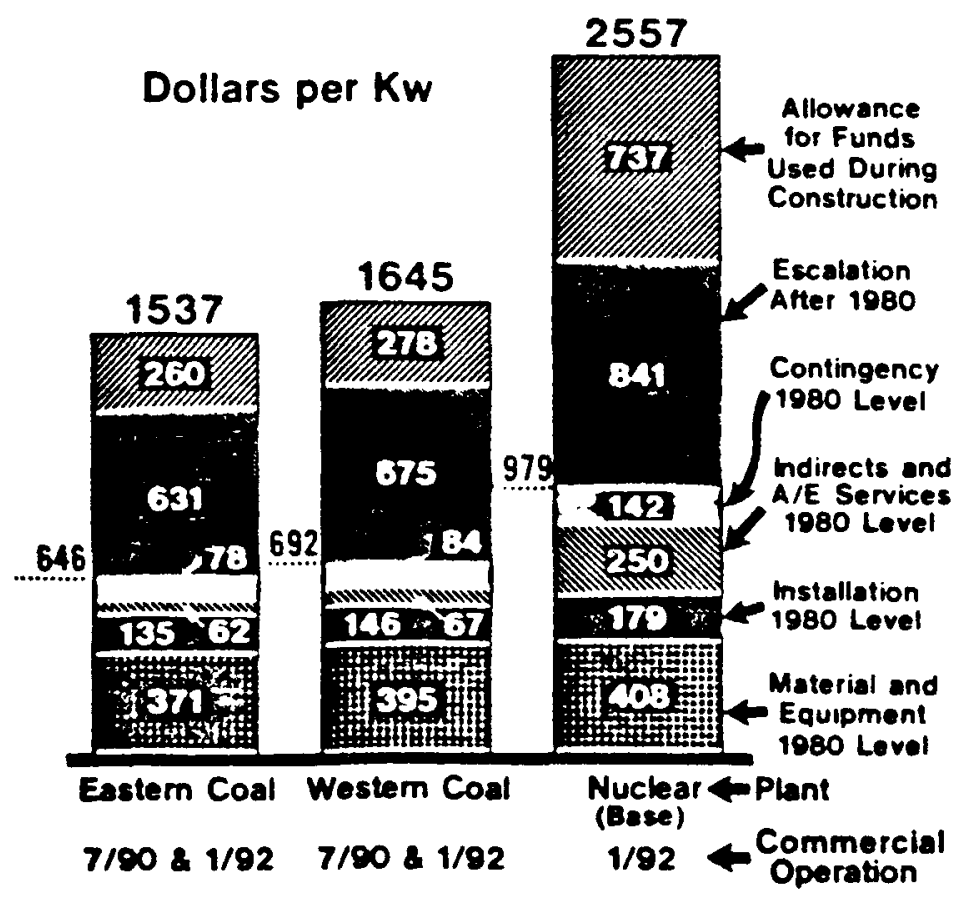


Industrial Forum have prepared order-of-magnitude estimates. Based on the mid-range of these, the nuclear plant cost is estimated at $\$ 2,735 / \mathrm{kW}$, or an increase of about 7 percent.

\section{Coal Cost Estimates}

For coal plants located in the east, eastern high-sulfur coal was assumed to be hauled by train 600 miles to the plant site. In the west, western low-sulfur coal was delivered by train a distance of 1000 miles. The 1980 price for $12,000 \mathrm{Btu} / 1 \mathrm{~b}$ eastern coal is estimated at $\$ 31 /$ ton at the mine, and coal price escalation is assumed at $2 \%$ above the GNP price deflator. Rail shipment is based on a 1.67 /ton-mile or about $\$ 10 /$ ton in 1980 . Eastern rail rates are assumed to escalate at a rate $3 \%$ above the GNP price deflator.

For western coal $(8,000 \mathrm{Btu} / \mathrm{lb})$, the 1980 price is estimated to be $\$ 7.75$ at the mine and again coal price escalation is assumed to be $2 \%$ above the GNP price deflator. Rail shipment is based on a rate of $1.14 \xi /$ ton-mile or about $\$ 11.40 /$ ton in 1980 . Western rail rates are assumed to escalate at a slightly higher rate of $3.5 \%$ above the GNP price deflator.

\section{Nuclear Fuel Costs}

Short and long term price and escalation rates for fuel cycle services are projected assuming comparative market stability. For the short term, to 1985 , lower demand coupled with ample supply will reduce the pressure on fuel cycle costs. For the long term, 1986 on, the study projects that a stronger market for uranium and fuel cycle services 
will be in place. To forecast the trend of future price changes from 1980, nuclear fuel cycle cost component escalation rates are based on historical and projected relationships between the GNP price deflator and various labor and material indices related to each component of the nuclear fuel cycle. Typical values for uranium, UF 6 conversion, enrichment, fabrication, and spent fuel management or reprocessing and the projected escalation rates are provided in Table 3.

\section{$\underline{\text { O\&M Costs }}$}

For purposes of the comparison, the study assumes a typical utility and develops estimates of plant staffing requirements and maintenance material costs. For the nuclear plant, radwaste reprocessing and an adjustment for the TMI impact on operating costs are included. The coal-fired plant costs include FGD reagent, sludge stabilization additives, and on-site waste disposal costs. On a levelized basis (over the first 10 years of operation), the study estimates the eastern coal plant $O \& M$ cost to be $8.6 \mathrm{mills} / \mathrm{kWh}, 7.5 \mathrm{mills} / \mathrm{kWh}$ for the western coal plant, and $7.5 \mathrm{mills} / \mathrm{kWh}$ for the nuclear plant.

Bus Bar Energy Cost

Included in the bus bar energy cost for the coal plants are: fixed charges on the plant, fixed charges on a 60-day coal storage pile, fue1, and $O \& M$ costs. A decommissioning cost is not included for the coal plants.

The nuclear plant cost includes: fixed charges on the plant (which includes the TMI additions), O\&M, fuel carrying charges and fuel 
TABLE 3

\section{NUCLEAR FUEL COST PROJECTION}

\begin{tabular}{|c|c|c|c|c|}
\hline ITEM & UNIT & $\begin{array}{c}\text { PRICE } \\
\text { JANUARY } 1980 \\
\end{array}$ & $\begin{array}{c}\text { ANNUAL } \\
\text { ESCALATION - } \\
\text { PERCENT } \\
\end{array}$ & PERIOD \\
\hline $\mathrm{U}_{3} \mathrm{O}_{8}$ & $S / L B U_{3} O_{8}$ & 38 & $\begin{array}{l}6.0 \\
9.5\end{array}$ & $\begin{array}{c}1980-1985 \\
1986 \& \\
\text { THEREAFTER }\end{array}$ \\
\hline CONVERSION & s/kg & 5.30 & 6.2 & $\begin{array}{c}19808 \\
\text { THEREAFTER }\end{array}$ \\
\hline ENRICHMENT & s/Swu & 111 & 6.2 & $\begin{array}{c}19808 \\
\text { THEREAFTER }\end{array}$ \\
\hline FABRICATION & S/kgu & 138 & 6.2 & $\begin{array}{c}1980 \& \\
\text { THEREAFTER }\end{array}$ \\
\hline $\begin{array}{l}\text { SPENT FUEL } \\
\text { MANAGEMENT }\end{array}$ & S/kgu & 260 & 6.2 & $\begin{array}{c}1980 \& \\
\text { THEREAFTER }\end{array}$ \\
\hline RECOVERY & s/kgu & 424 & 6.2 & $\begin{array}{c}1980 \& \\
\text { THEREAFTER }\end{array}$ \\
\hline Pu CREDIT & S/gm FPu & 20.4 & 6.2 & $\begin{array}{c}1980 \& \\
\text { THEREAFTER }\end{array}$ \\
\hline
\end{tabular}


burnup based on no reprocessing, and nuclear plant decommissioning. . The cost of decommissioning assumes immediate dismantling of the facility at the end of its operating life and funds are provided by establishing a sinking fund over the plant's life.

Figure 2 indicates that a nuclear plant is preferred to either coal alternative. The nuclear plant has a bus bar energy cost of 119.7 mills/kWh, about 11.5 percent lower than the eastern coal plant's $135.2 \mathrm{mills} / \mathrm{kWh}$. Nuclear is estimated to be 2.7 percent 1 ower than the western coal plant's $123.1 \mathrm{mills} / \mathrm{kWh}$ for a marginal advantage, essentially a standoff considering the accuracy of the estimates.

Figure 3 demonstrates the sensitivity of the analysis to changes in the nuclear plants investment cost. When compared to an eastern coal plant, the nuclear plant investment cost would have to increase by about 17 percent to reach a break-even point. The comparison to western coal indicates the nuclear investment would have to increase about 4 percent to reach the break-even point.

Mr. Kettler has advised that a preliminary review of both nuclear and coal capital cost estimates, performed by Ebasco in September 1981, has indicated continued capital cost increases due to technological change as well as higher projected rates of escalation and AFUDC. Continued cost increases will narrow nuclear's bus bar energy cost advantage over eastern coal and probably show an advantage for western coal based on ten-year levelized cost. However, 30 year life-cyclelevelized cost probably would indicate that nuclear plants still maintain a generic economic advantage over coal, assuming a political licensing scenario that enables a utility to authorize design, construct and bring on line a nuclear unit within 12 years. 


\section{LEVELIZED BUS BAR ENERGY COSTS} FIRST TEN YEARS OF PLANT OPERATION (65\%CF) 1980 Estimate Mills per Kwh

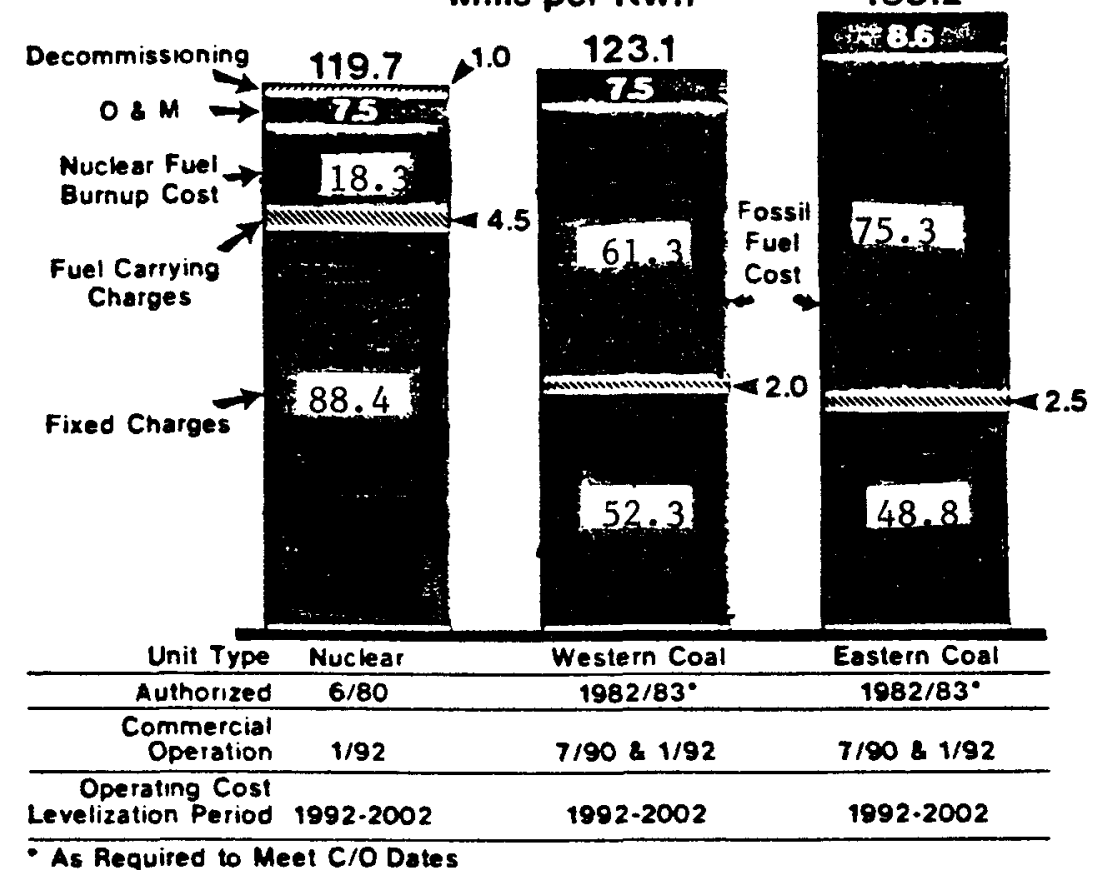

FIGURE 3

\section{SENSITIVITY ANALYSIS NUCLEAR PLANT INVESTMENT}

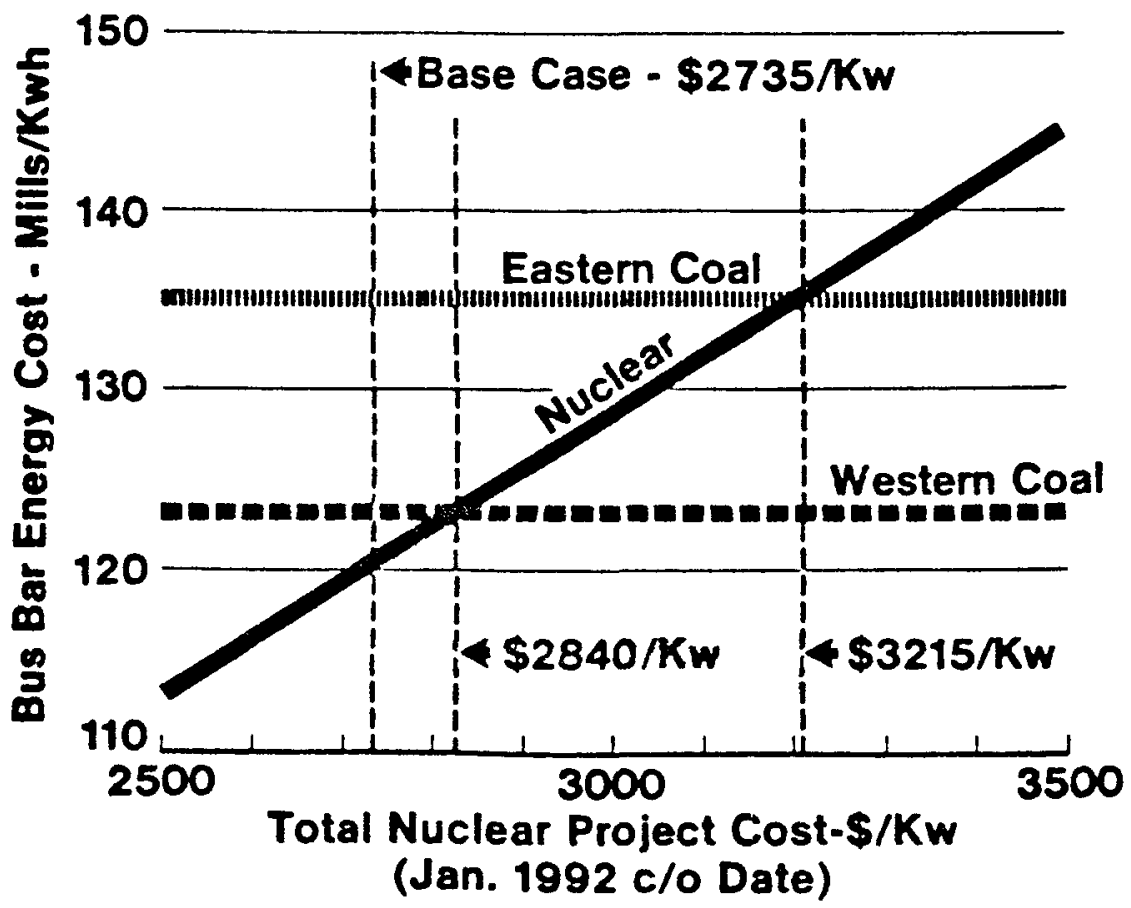


IV. OPERATION

A. NERC - Ten Year Review on Equipment Availability and Component Cause Code Report

The National Electric Reliability Council (NERC) published its "Ten Year Review - 1971-1980 Report on Equipment Availability" and "Ten Year Review 1971-1980 Component Cause Code Report". The two reports form a data base on the performance of major types of electric power generating units belonging to over 160 utilities in the United States. These units include nuclear, hydro, fossil, and non-steam fossil. Fossil units include those steam units that burn fossil fuel; e.g., coal, oil, gas and 1ignite. Non-steam fossil units include diesels, gas turbines, and jet engines.

The reported statistics and information were derived from outage and summary reports of individual units, as submitted by the reporting utilities. The input data were subjected to validation checks through programs developed by the NERC Generating Availability Data System. Data believed to contain errors were returned to the reporting utility for further review. The corrected data were rechecked by NERC and entered into the master data files. Thus, primary responsibility for data accuracy lies with the reporting utilities.

Table $11 /, 2 /$ provides a summary report of the power plants studied over the ten year period. The table indicates the number of plants in the study and reports the summary results on a unit average. For example, the table shows that, on the average, the typical fossil

1/ Certain Table and Figure numbers have been changed for editorial purposes. $\underline{2} /$ Definitions can be found starting on page 87 . 
ALL UNITS 1971-1980

UNIT YEAR AVERAGES

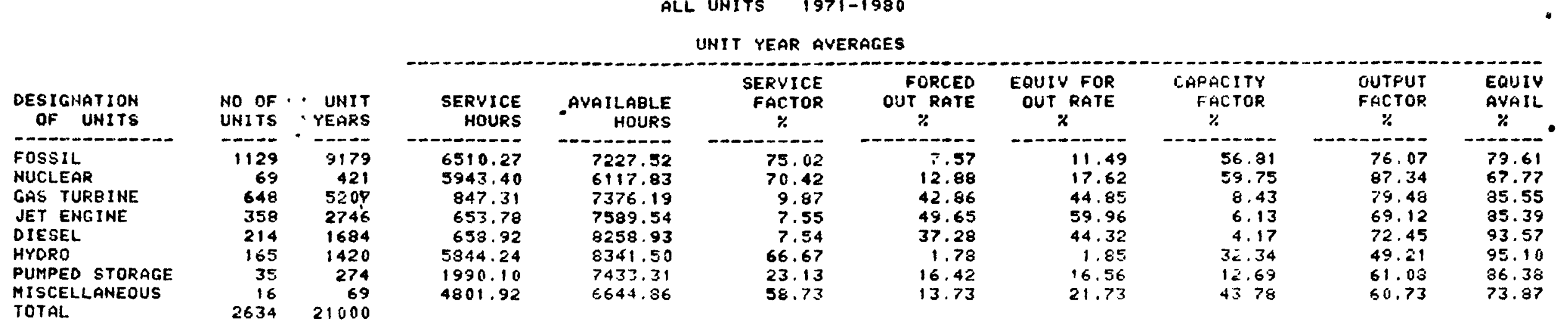

DESIGNATIOH OF UNITS

FOSSIL

NUCLEAR

GAS TURBIHE

O JET ENGINE

DIESEL

HYDRO

PUMPED STORAGE

MISCELLANEOUS

TOTAL

\begin{tabular}{l} 
OESIGHAYION \\
OF UNITS \\
\hline FOSSIL \\
NUCLEAR \\
GAS TURBIHE \\
JET ENGINE \\
DIESEL \\
HYDRO \\
PUMPED STORAGE \\
MISCELLATEGUS \\
TOTAL
\end{tabular}

MISCELLAATEGUS

TOTAL.

UNIT YEAR AUERAGES

\begin{tabular}{|c|c|c|c|c|c|c|c|}
\hline $\begin{array}{l}\text { UFERATING } \\
\text { AVAILABILITY } \\
\%\end{array}$ & $\begin{array}{c}\text { SCHEQULEO } \\
\text { OUTAGE RATE } \\
\%\end{array}$ & $\begin{array}{c}\text { FORCED OUTAGE } \\
\text { RHTIO } \\
\because\end{array}$ & $\begin{array}{c}\text { FORCED OUTACE } \\
\text { IHCIDENT RATE } \\
\%\end{array}$ & $\begin{array}{l}\text { MEAN TIME } \\
\text { EETWEE S FULL } \\
\text { FORCED OUTAEES }\end{array}$ & $\begin{array}{l}\text { STA } \\
\text { NO } \\
\text { TRIEO }\end{array}$ & $\begin{array}{l}\text { P.TS } \\
\text { HOC. }\end{array}$ & $\begin{array}{l}\text { NO. } \\
\text { YRS }\end{array}$ \\
\hline $\begin{array}{l}83.28 \\
72.49\end{array}$ & $\begin{array}{l}11.51 \\
19.19\end{array}$ & $\begin{array}{l}36.81 \\
37.86\end{array}$ & $\begin{array}{l}67.66 \\
70.71\end{array}$ & $\begin{array}{l}803.68 \\
850.17\end{array}$ & $\begin{array}{l}77.6 \\
17.8\end{array}$ & $\begin{array}{l}33.4 \\
14.1\end{array}$ & $\begin{array}{r}1071 \\
129\end{array}$ \\
\hline 85.95 & 6.78 & 52.76 & 56.56 & 902.03 & 151.3 & 123.5 & 3902 \\
\hline 87.70 & 4.89 & 60.62 & 50.85 & 877.95 & 142.6 & 122.0 & 2035 \\
\hline 34.51 & 1.00 & 81.69 & 68.03 & 1106.75 & 192.6 & $17: 6$ & 795 \\
\hline 95.16 & 3.77 & 25.12 & 23.13 & 3538.30 & 072.6 & 532.6 & 53 \\
\hline $8 E .41$ & 9.26 & 33.49 & 32.91 & $1124, \overline{9}$ & 576.9 & 497.4 & 94 \\
\hline 81.28 & 11.09 & 49.95 & $8 \overline{3} 00$ & 1116.97 & 98.0 & $5 \overline{8} .0$ & 25 \\
\hline
\end{tabular}

UNIT YEAR AVERAGES

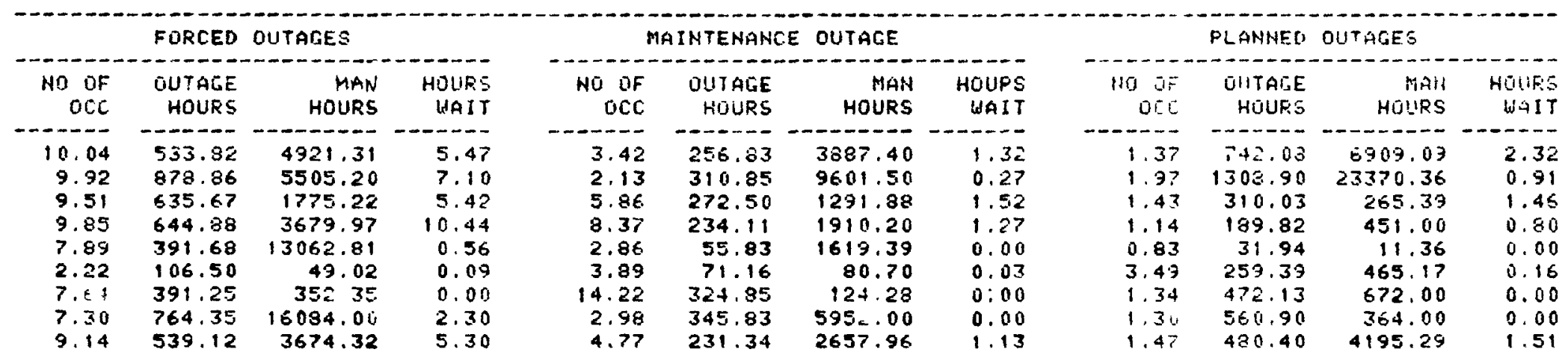


unit was available for 7227.52 hours in a year while the typical nuclear unit was available for 6117.83 . This value reflects the 912.49 hours, on the average, that a nuclear plant was down each year to refuel.

As can also be observed, nuclear units had a higher capacity factor than coal $(59.75 \%$ vs. $56.81 \%$ ) as well as compared to all other types of power plants. This also held true for their output factors. The annual changes in the capacity factors for large coal and nuclear plants are depicted in Figure 1.

The overall trend of the reported data confirms the view that capita1intensive power plants should be used for base-load generation and that fuel-intensive plants should provide peaking generation; this is due to the higher marginal costs of the fuel-intensive units. As expected, the fuel-intensive power plants, such as gas turbine, pumped storage, jet engine, and diesel, had very low service factors and low capacity factors. Fossil, nuclear and hydro had significantly higher service factors and capacity factors.

The import of this result is--given the wide fluctuations in electricity demand during the 24 hours of the day as well as during the seasons of the year--the most economical means to supply this basing and peaking is with a mixture of technologies that vary in their economic and technical characteristics. Moreover, not only do the characteristics vary from technology to technology but also from plant size to plant size within any given technology (see Figure 2). 


\section{Comparison of Fossil (Coal Primary) Units $400 \mathrm{MW}$ and Above to All Nuclear Units}

\section{UNIT YEAR AVERAGES \\ 1971.1980}

SAMPLE TABLE

\begin{tabular}{|c|c|c|}
\hline $\begin{array}{c}\text { Year of } \\
\text { Operation }\end{array}$ & $\begin{array}{c}\text { Fossil } \\
\text { (Coal Primary) } \\
400 \mathrm{MW} \\
\text { and Above } \\
\text { No of Units }\end{array}$ & $\begin{array}{c}\text { Nuclear } \\
\text { Nu of Units }\end{array}$ \\
\hline 1971 & 63 & 11 \\
\hline 1972 & 80 & 11 \\
\hline 1973 & 93 & 22 \\
\hline 1974 & 108 & 42 \\
\hline 1975 & 119 & 49 \\
\hline 1976 & 128 & 53 \\
\hline 1977 & 109 & 57 \\
\hline 1978 & 131 & 53 \\
\hline 1979 & 141 & 63 \\
\hline 1980 & 164 & 60 \\
\hline
\end{tabular}

FOSSIť $\ldots \ldots \ldots \ldots$

*Coal primary fuel

$* *$ Those reporting to NERC

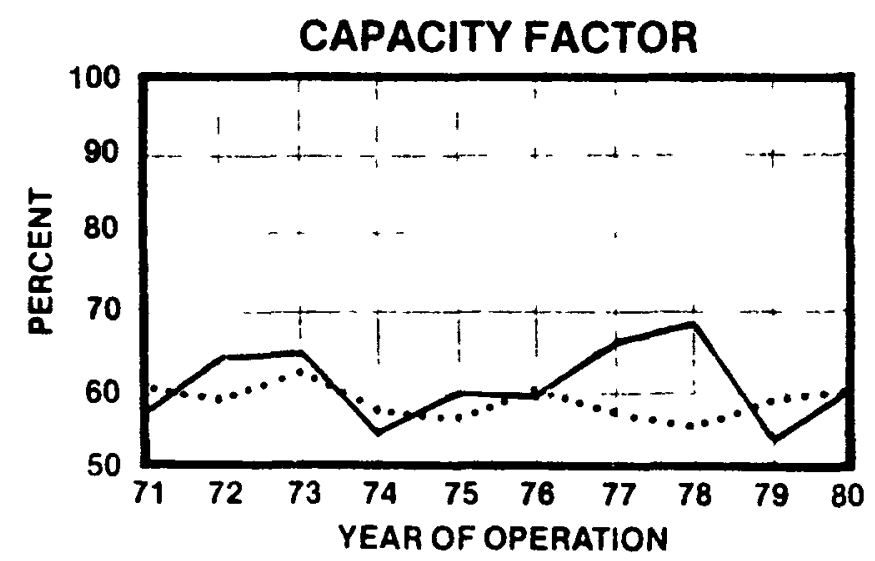

YEAR

\begin{tabular}{|c|c|c|c|c|c|c|c|c|c|c|}
\hline Capacity Factor & 71 & 72 & 73 & 74 & 75 & 76 & 77 & 78 & 79 & 80 \\
\hline Fossil & 60.0 & 59.6 & 62.4 & 57.7 & 57.3 & 59.4 & 57.4 & 55.3 & 58.3 & 59.5 \\
\hline Nuclear & 56.9 & 63.1 & 64.1 & 53.6 & 59.4 & 59.0 & 65.2 & 68.3 & 52.9 & 59.5 \\
\hline
\end{tabular}


FOSSIL UNIT COMPARISON OF SERVICE AND CAPACITY FACTORS

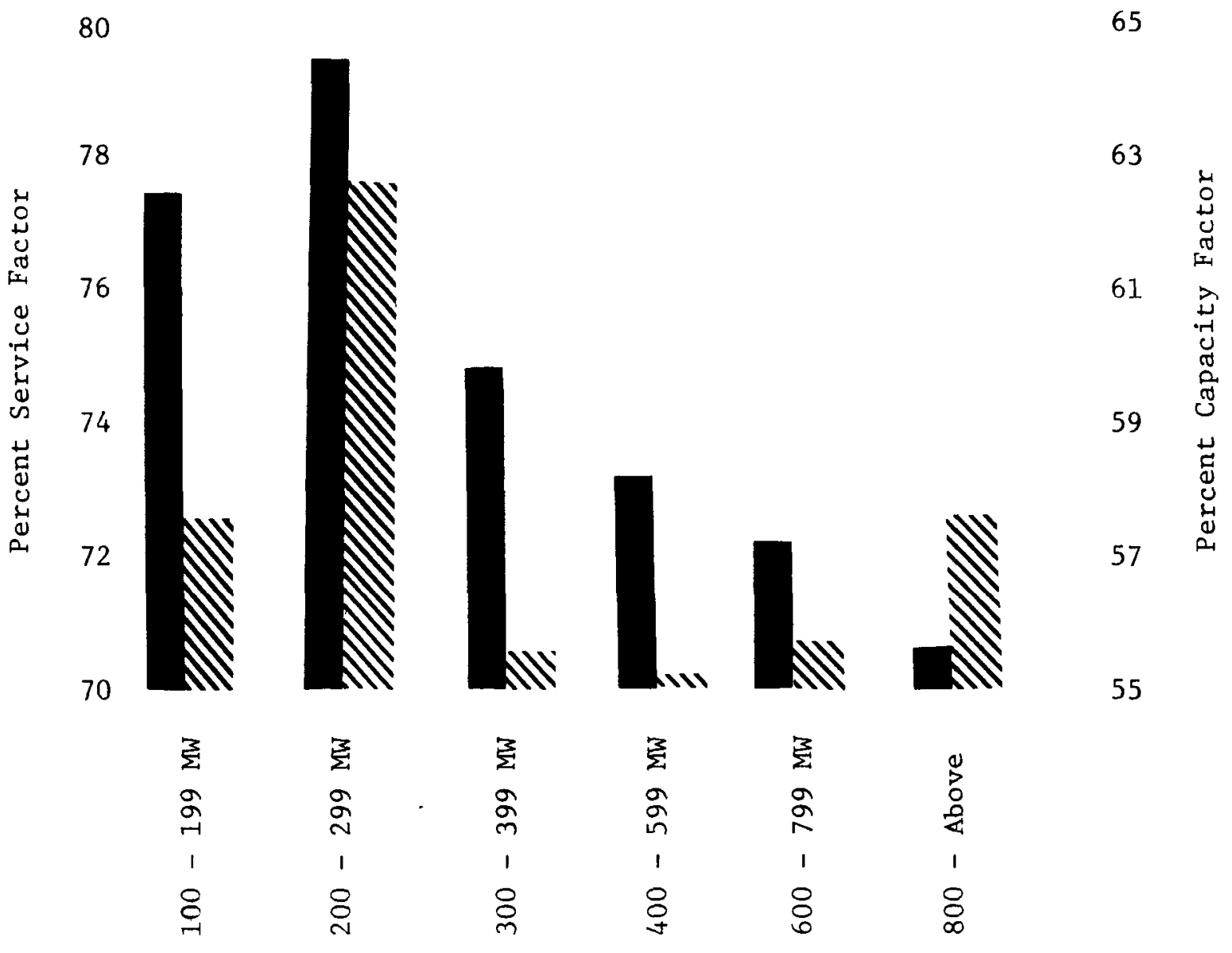

Size

$$
\begin{aligned}
& 100-199 \mathrm{MW} \\
& 200-299 \mathrm{MW} \\
& 300-399 \mathrm{MW} \\
& 400-599 \mathrm{MW} \\
& 600-799 \mathrm{MW} \\
& 800 \text { - Above }
\end{aligned}
$$

\section{Service Factor}

77.31

79.40

74.87

73.06

72.15

70.63

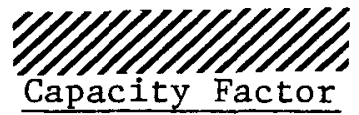

57.65

62.62

55.64

55.21

55.80

57.65 
In addition, the fossil category, as noted previously, includes coal, oil, gas, and lignite, each with its own characteristics (see Table 2). Nuclear, a technology that is capital intensive, has characteristics that enable higher capacity and service factors and thus is ideally suited for providing base-load generation. This is evidenced by its extremely high output factor $(87.34 \%)$ over the ten year period as well as its very low economy outage rate. An economy outage is when a unit is taken out of service because another unit is capable of providing the quantity of electricity needed at a lower cost. As given in the NERC report, the nuclear economy outages occurred at a very low rate of $2.06 \%$ per year per plant during the decade whereas the fossil economy outage rate was $8.29 \%$ per year per plant.

Analyses of the causes of plant outages are provided on Tables 3 and 4. Here, the outages are separated into four categories: Forced, Planned, Maintenance, and Non-Curtailing. Forced Outages occurred more often per year, on the average, than the three other outage categories for both the nuclear and fossil units. The causes of the outages for each category are divided into the major plant systems such as the generator, turbine, and steam supply. Both the fossil units and the nuclear units exhibited similar trends in that the most common causes of plant outage were attributable to the steam supply system and to problems that affected the entire plant. 


\begin{tabular}{|c|c|c|c|c|c|c|c|c|c|c|c|c|}
\hline $\begin{array}{l}\text { Unit } \\
\text { Sample }\end{array}$ & $\begin{array}{l}\text { Performance } \\
\text { Index }\end{array}$ & $\begin{array}{l}\text { Year: } \\
1971\end{array}$ & 1972 & 1973 & 1974 & 1975 & 1976 & 1977 & 1978 & 1979 & 1980 & $1971 \cdot 1980$ \\
\hline COAL & $\begin{array}{l}\text { AF } \\
\text { EAF }\end{array}$ & $\begin{array}{l}756 \\
693\end{array}$ & $\begin{array}{l}753 \\
692\end{array}$ & $\begin{array}{l}780 \\
731\end{array}$ & $\begin{array}{l}749 \\
678\end{array}$ & $\begin{array}{l}742 \\
661\end{array}$ & $\begin{array}{l}733 \\
662\end{array}$ & $\begin{array}{ll}711 \\
651\end{array}$ & $\begin{array}{l}734 \\
655 \\
\end{array}$ & $\begin{array}{l}748 \\
676 \\
\end{array}$ & $\begin{array}{l}758 \\
701 \\
\end{array}$ & $\begin{array}{l}746 \\
678 \\
\end{array}$ \\
\hline \multirow[t]{4}{*}{ PRIMARY } & $\begin{array}{l}\text { FOA } \\
\text { EFOR }\end{array}$ & $\begin{array}{l}161 \\
227\end{array}$ & $\begin{array}{l}140 \\
198\end{array}$ & $\begin{array}{l}146 \\
200\end{array}$ & $\begin{array}{l}169 \\
247\end{array}$ & $\begin{array}{l}148 \\
239 \\
\end{array}$ & $\begin{array}{l}152 \\
227 \\
\end{array}$ & $\begin{array}{l}171 \\
236\end{array}$ & $\begin{array}{l}165 \\
251 \\
\end{array}$ & $\begin{array}{l}143 \\
222 \\
\end{array}$ & $\begin{array}{l}121 \\
184 \\
\end{array}$ & $\begin{array}{l}150 \\
223 \\
\end{array}$ \\
\hline & $\begin{array}{l}\text { SOA } \\
\text { SF }\end{array}$ & $\begin{array}{r}112 \\
699 \\
\end{array}$ & $\begin{array}{l}141 \\
713 \\
\end{array}$ & $\begin{array}{l}116 \\
733 \\
\end{array}$ & $\begin{array}{l}128 \\
722 \\
\end{array}$ & $\begin{array}{l}136 \\
719 \\
\end{array}$ & $\begin{array}{l}153 \\
720 \\
\end{array}$ & $\begin{array}{l}157 \\
707 \\
\end{array}$ & $\begin{array}{l}125 \\
720 \\
\end{array}$ & $\begin{array}{l}136 \\
728 \\
\end{array}$ & $\begin{array}{l}142 \\
747 \\
\end{array}$ & $\begin{array}{l}136 \\
723 \\
\end{array}$ \\
\hline & $\begin{array}{l}\text { OF } \\
\text { CF }\end{array}$ & $\begin{array}{l}856 \\
590 \\
\end{array}$ & $\begin{array}{l}856 \\
607 \\
\end{array}$ & $\begin{array}{l}852 \\
620 \\
\end{array}$ & $\begin{array}{l}818 \\
587 \\
\end{array}$ & $\begin{array}{l}804 \\
580 \\
\end{array}$ & $\begin{array}{l}824 \\
596 \\
\end{array}$ & $\begin{array}{l}821 \\
576 \\
\end{array}$ & $\begin{array}{l}797 \\
576 \\
\end{array}$ & $\begin{array}{l}820 \\
598 \\
\end{array}$ & $\begin{array}{l}840 \\
628 \\
\end{array}$ & $\begin{array}{r}825 \\
596 \\
\end{array}$ \\
\hline & $\begin{array}{l}\text { Sample } \\
\text { Size }\end{array}$ & 31 & 43 & 55 & 64 & 70 & 74 & 55 & 67 & 74 & 85 & 97 \\
\hline OlL & $\begin{array}{l}\text { AF } \\
\text { EAF }\end{array}$ & $\begin{array}{l}816 \\
799 \\
\end{array}$ & $\begin{array}{l}830 \\
796\end{array}$ & $\begin{array}{l}730 \\
632\end{array}$ & $\begin{array}{l}826 \\
750\end{array}$ & $\begin{array}{l}757 \\
688\end{array}$ & $\begin{array}{l}721 \\
664\end{array}$ & $\begin{array}{l}750 \\
693\end{array}$ & $\begin{array}{l}764 \\
708\end{array}$ & $\begin{array}{l}745 \\
680\end{array}$ & $\begin{array}{l}789 \\
734\end{array}$ & $\begin{array}{l}765 \\
706\end{array}$ \\
\hline \multirow[t]{4}{*}{ PRIMARY } & $\begin{array}{l}\text { FOR } \\
\text { EFOR }\end{array}$ & $\begin{array}{l}100 \\
114 \\
\end{array}$ & $\begin{array}{l}54 \\
69 \\
\end{array}$ & $\begin{array}{l}158 \\
262 \\
\end{array}$ & $\begin{array}{r}87 \\
182 \\
\end{array}$ & $\begin{array}{l}141 \\
219 \\
\end{array}$ & $\begin{array}{r}77 \\
153\end{array}$ & $\begin{array}{l}133 \\
201\end{array}$ & $\begin{array}{r}86 \\
154\end{array}$ & $\begin{array}{l}157 \\
235\end{array}$ & $\begin{array}{r}86 \\
163\end{array}$ & $\begin{array}{ll}110 \\
180\end{array}$ \\
\hline & $\begin{array}{l}\text { SOR } \\
\text { SF }\end{array}$ & $\begin{array}{r}94 \\
802\end{array}$ & $\begin{array}{l}143 \\
825\end{array}$ & $\begin{array}{l}145 \\
730\end{array}$ & $\begin{array}{l}113 \\
657\end{array}$ & $\begin{array}{l}146 \\
645\end{array}$ & $\begin{array}{l}241 \\
625\end{array}$ & $\begin{array}{ll}171 \\
670\end{array}$ & $\begin{array}{l}178 \\
702\end{array}$ & $\begin{array}{l}156 \\
621\end{array}$ & $\begin{array}{l}173 \\
618\end{array}$ & $\begin{array}{l}166 \\
669\end{array}$ \\
\hline & $\begin{array}{l}\mathrm{OF} \\
\mathrm{CF}\end{array}$ & $\begin{array}{l}822 \\
627\end{array}$ & $\begin{array}{l}789 \\
630\end{array}$ & $\begin{array}{l}757 \\
545 \\
\end{array}$ & $\begin{array}{l}684 \\
436 \\
\end{array}$ & $\begin{array}{r}649 \\
429 \\
\end{array}$ & $\begin{array}{l}690 \\
440 \\
\end{array}$ & $\begin{array}{r}683 \\
458 \\
\end{array}$ & $\begin{array}{l}692 \\
486 \\
\end{array}$ & $\begin{array}{l}630 \\
393 \\
\end{array}$ & $\begin{array}{l}595 \\
377 \\
\end{array}$ & $\begin{array}{l}677 \\
452 \\
\end{array}$ \\
\hline & $\begin{array}{l}\text { Sample } \\
\text { Size }\end{array}$ & 6 & 7 & 5 & 8 & 12 & 14 & 20 & 19 & 18 & 17 & 28 \\
\hline GAS & $\begin{array}{l}\text { AF } \\
\text { EAF }\end{array}$ & $\begin{array}{l}579 \\
558\end{array}$ & $\begin{array}{l}610 \\
609\end{array}$ & $\begin{array}{l}783 \\
736\end{array}$ & $\begin{array}{l}776 \\
741\end{array}$ & $\begin{array}{l}795 \\
769 \\
\end{array}$ & $\begin{array}{l}783 \\
746\end{array}$ & $\begin{array}{l}737 \\
714 \\
\end{array}$ & $\begin{array}{l}729 \\
685\end{array}$ & $\begin{array}{l}858 \\
785\end{array}$ & $\begin{array}{l}749 \\
673 \\
\end{array}$ & $\begin{array}{l}768 \\
727 \\
\end{array}$ \\
\hline \multirow[t]{4}{*}{ PRIMARY } & $\begin{array}{l}\text { FOR } \\
\text { EFOR }\end{array}$ & $\begin{array}{l}360 \\
361 \\
\end{array}$ & $\begin{array}{l}325 \\
327\end{array}$ & $\begin{array}{r}83 \\
129\end{array}$ & $\begin{array}{r}68 \\
108\end{array}$ & $\begin{array}{r}98 \\
125\end{array}$ & $\begin{array}{l}32 \\
78\end{array}$ & $\begin{array}{l}127 \\
157\end{array}$ & $\begin{array}{l}163 \\
216\end{array}$ & $\begin{array}{r}47 \\
128\end{array}$ & $\begin{array}{r}53 \\
145\end{array}$ & $\begin{array}{r}97 \\
143\end{array}$ \\
\hline & $\begin{array}{l}\text { SOR } \\
\text { SF }\end{array}$ & $\begin{array}{l}116 \\
579\end{array}$ & $\begin{array}{l}144 \\
572\end{array}$ & $\begin{array}{l}172 \\
734\end{array}$ & $\begin{array}{l}178 \\
730\end{array}$ & $\begin{array}{l}124 \\
734\end{array}$ & $\begin{array}{l}791 \\
767\end{array}$ & $\begin{array}{l}163 \\
695 \\
\end{array}$ & $\begin{array}{l}145 \\
688\end{array}$ & $\begin{array}{l}101 \\
807\end{array}$ & $\begin{array}{l}209 \\
745\end{array}$ & $\begin{array}{l}160 \\
728 \\
\end{array}$ \\
\hline & $\begin{array}{l}\mathrm{OF} \\
\mathrm{CF} \\
\end{array}$ & $\begin{array}{l}689 \\
399 \\
\end{array}$ & $\begin{array}{l}799 \\
480 \\
\end{array}$ & $\begin{array}{l}764 \\
550 \\
\end{array}$ & $\begin{array}{l}733 \\
517 \\
\end{array}$ & $\begin{array}{l}732 \\
523 \\
\end{array}$ & $\begin{array}{l}705 \\
536 \\
\end{array}$ & $\begin{array}{l}638 \\
417 \\
\end{array}$ & $\begin{array}{l}741 \\
497 \\
\end{array}$ & $\begin{array}{l}640 \\
516 \\
\end{array}$ & $\begin{array}{l}614 \\
459 \\
\end{array}$ & $\begin{array}{l}707 \\
507 \\
\end{array}$ \\
\hline & $\begin{array}{l}\text { Sample } \\
\text { Size }\end{array}$ & 1 & 4 & 11 & 12 & 12 & 10 & 5 & 6 & 6 & 7 & 15 \\
\hline ALL FOSSIL & $\begin{array}{l}\text { AF } \\
\text { EAF }\end{array}$ & $\begin{array}{l}751 \\
698\end{array}$ & $\begin{array}{l}757 \\
705\end{array}$ & $\begin{array}{l}778 \\
726\end{array}$ & $\begin{array}{l}760 \\
693\end{array}$ & $\begin{array}{l}750 \\
678\end{array}$ & $\begin{array}{l}737 \\
671\end{array}$ & $\begin{array}{l}722 \\
665\end{array}$ & $\begin{array}{l}741 \\
669\end{array}$ & $\begin{array}{l}746 \\
677\end{array}$ & $\begin{array}{l}761 \\
702\end{array}$ & $\begin{array}{l}749 \\
686\end{array}$ \\
\hline FUEL & $\begin{array}{l}\text { FOA } \\
\text { EFOR }\end{array}$ & $\begin{array}{l}160 \\
214\end{array}$ & $\begin{array}{l}139 \\
187\end{array}$ & $\begin{array}{l}138 \\
194\end{array}$ & $\begin{array}{l}150 \\
224\end{array}$ & $\begin{array}{l}141 \\
222\end{array}$ & $\begin{array}{ll}131 \\
204\end{array}$ & $\begin{array}{l}160 \\
223\end{array}$ & $\begin{array}{l}152 \\
233\end{array}$ & $\begin{array}{l}148 \\
226\end{array}$ & $\begin{array}{ll}111 \\
180\end{array}$ & $\begin{array}{l}141 \\
212\end{array}$ \\
\hline \multirow[t]{3}{*}{ TYPES ${ }^{*}$} & $\begin{array}{l}\text { SOR } \\
\text { SF }\end{array}$ & $\begin{array}{l}113 \\
703\end{array}$ & $\begin{array}{l}140 \\
712\end{array}$ & $\begin{array}{l}125 \\
735\end{array}$ & $\begin{array}{l}134 \\
717\end{array}$ & $\begin{array}{l}136 \\
712\end{array}$ & $\begin{array}{l}169 \\
712\end{array}$ & $\begin{array}{l}161 \\
697\end{array}$ & $\begin{array}{l}134 \\
717\end{array}$ & $\begin{array}{l}138 \\
710\end{array}$ & $\begin{array}{l}752 \\
728\end{array}$ & $\begin{array}{l}143 \\
715\end{array}$ \\
\hline & $\begin{array}{l}\mathrm{OF} \\
\mathrm{CF}\end{array}$ & $\begin{array}{l}860 \\
595 \\
\end{array}$ & $\begin{array}{l}838 \\
592\end{array}$ & $\begin{array}{l}834 \\
607\end{array}$ & $\begin{array}{l}796 \\
564\end{array}$ & $\begin{array}{l}778 \\
555\end{array}$ & $\begin{array}{l}796 \\
569\end{array}$ & $\begin{array}{l}780 \\
539\end{array}$ & $\begin{array}{l}770 \\
552\end{array}$ & $\begin{array}{l}774 \\
552\end{array}$ & $\begin{array}{l}790 \\
578\end{array}$ & $\begin{array}{l}793 \\
566\end{array}$ \\
\hline & $\begin{array}{l}\text { Sample } \\
\text { Size }\end{array}$ & 43 & 57 & 72 & 84 & 94 & 98 & 80 & 108 & 114 & 117 & 124 \\
\hline
\end{tabular}


FÜSSIL UNITS $1971-1980$

SELECTEO FOSSIL UINTTS NO OF SYSTEMS 126 NI OF UNITS 1129 NO OF UNIT YEAES SIT9

\begin{tabular}{|c|c|c|c|c|}
\hline \multicolumn{2}{|c|}{$\begin{array}{c}\text { UHIT } \\
\text { STATISTICS }\end{array}$} & & FOR.CED & $\begin{array}{l}\text { OPERATIHC } \\
\text { AVOILABILIT: }\end{array}$ \\
\hline$\cdots \cdots$ & CUNULATIVE & $\begin{array}{l}\text { CAUSE } \\
\text { CODE }\end{array}$ & CUMIULTIVE-\% & CUMULATIJE-\% \\
\hline & 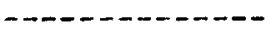 & $-\cdots--$ & 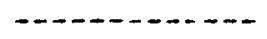 & 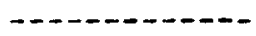 \\
\hline SERVICE HOIIFS & 59757840.71 & BOILEF & $4 . \varepsilon$ & $5 \overline{8} .8$ \\
\hline SEK'YICE FACTOR-\% & 75.02 & TURE INE & 1.5 & 930 \\
\hline AVAILABLE HOURS & 66341426.26 & COND. & 0.1 & 97.7 \\
\hline CAPACITY FACTOR-\% & 56.81 & EENH. & 05 & $98=$ \\
\hline OUTFUT FACTRIR-: & 76.07 & OTHEF & 0.0 & $47, c$ \\
\hline Eauly F.O.R. $-\%$ & 11.49 & UHIT & 7. & 33.2 \\
\hline SC.HEDULED UUIT RATE-\% & 11.51 & & & \\
\hline FQF.CEL OLIT FATIO-\% & 36.81 & & & \\
\hline F.O. INCIOENT RATE-\% & 07.66 & & & \\
\hline EQUIV AVAILABILIT'Z-:" & 79.61 & & & \\
\hline
\end{tabular}

MEAN TIME BETWEEN

FULL TOFEEG OUTHCES

LUMULATVE
1287.93
7149.45
23228.95
20387.02
6996.23
66.3 .68

FOFEET OUTAGE

MAINTENAMIE OLTARE

\begin{tabular}{|c|c|c|c|c|c|c|c|}
\hline \multicolumn{4}{|c|}{ UNIT YF AVR, } & \multicolumn{4}{|c|}{ CUMULATIVE } \\
\hline $\begin{array}{l}\text { Ho } \\
\text { occ }\end{array}$ & $\begin{array}{l}\text { OUTALE } \\
\text { HOLIFS }\end{array}$ & $\begin{array}{l}\text { MASA } \\
\text { HOUFS }\end{array}$ & $\begin{array}{r}\text { APS } \\
\text { WAIT }\end{array}$ & $\begin{array}{l}\text { nO } \\
\text { oct }\end{array}$ & $\begin{array}{l}\text { OUTAARE } \\
\text { HOUIFS }\end{array}$ & $\begin{array}{l}\text { MAN } \\
\text { HOUES }\end{array}$ & $\begin{array}{l}\text { HAUES } \\
\text { WATT }\end{array}$ \\
\hline$\cdots$ & 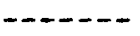 & $\ldots-$ & $-\cdots$ & $\ldots--$ & 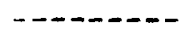 & $\ldots-\cdots$ & $\ldots-\cdots$ \\
\hline 7 & $\$ 23,98$ & 6341 & 4 & 61344 & 3019731.4 & 8358045 & 3436.4 \\
\hline 0 & 1.51 & 213 & 0 & 232 & 13875.3 & 280568 & 2636 \\
\hline 1 & 103.32 & 761 & 0 & $1114 n$ & 952964,5 & 1003424 & 2463 \\
\hline$a$ & 10.01 & 251 & 0 & 3428 & 91849.5 & 530000 & 237 \\
\hline 0 & 1.58 & 0 & $a$ & 296 & 15401.5 & 44 & $a$ \\
\hline i & 44,31 & 432 & 0 & J906. & 406758.4 & 569309 & 303 \\
\hline 1 & 44,75 & 1713 & 1 & 11364 & $4107<5.8$ & 2257458 & 10233 \\
\hline 10 & 53382 & 5918 & 5 & $922<3$ & 4899968.2 & 7800290 & 50247 \\
\hline
\end{tabular}

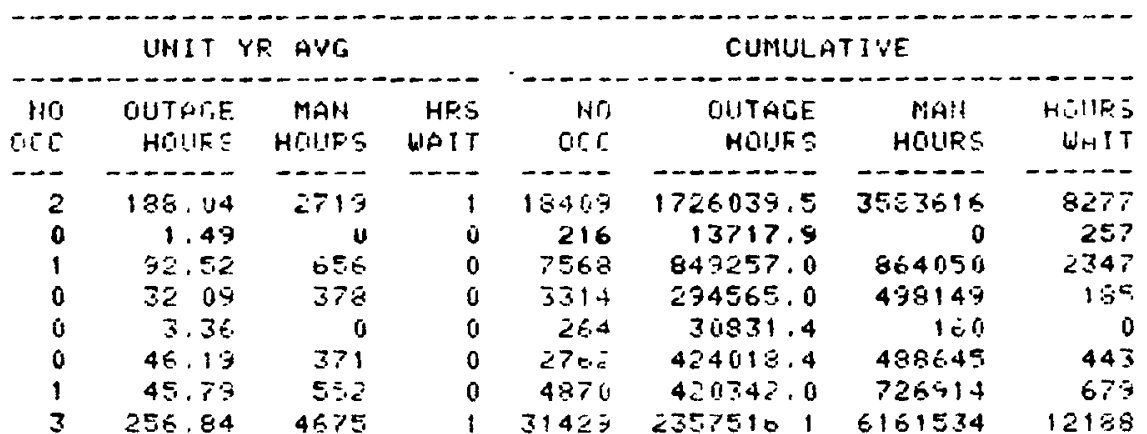

PLANHEd outages

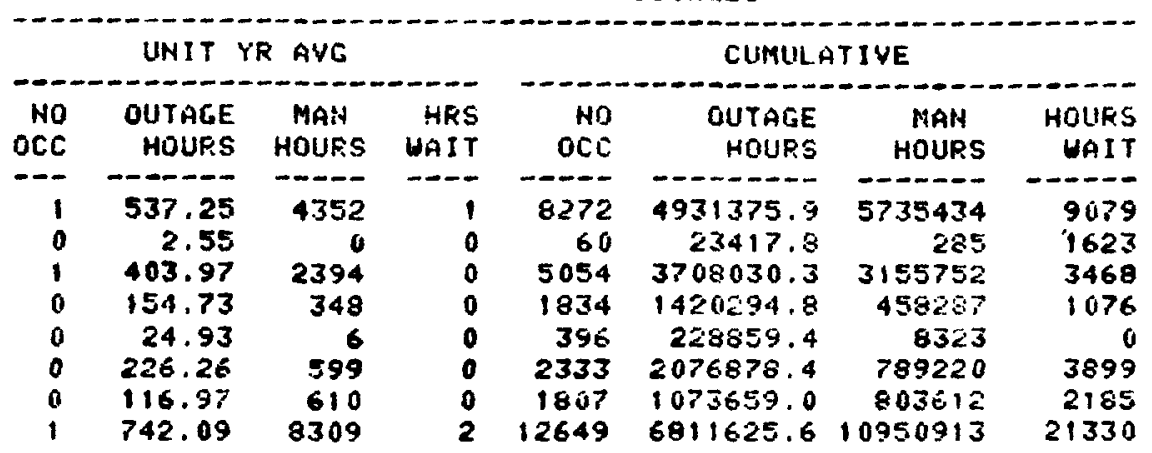

NONCURTAILIHG OUTAGES

\begin{tabular}{|c|c|c|c|c|c|c|c|}
\hline $\begin{array}{l}\text { NO } \\
\text { OCC }\end{array}$ & $\begin{array}{l}\text { OUTACE } \\
\text { HOUFS }\end{array}$ & $\begin{array}{l}\text { MAN } \\
\text { HOUPS }\end{array}$ & $\begin{array}{l}\text { HRS } \\
\text { WAIT }\end{array}$ & $\begin{array}{l}110 \\
\text { OCC }\end{array}$ & $\begin{array}{l}\text { OUTACE } \\
\text { HDURS }\end{array}$ & $\begin{array}{l}\text { MAN } \\
\text { HOURS }\end{array}$ & $\begin{array}{l}\text { HOURS } \\
\text { WAIT }\end{array}$ \\
\hline 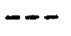 & $----m$ & $-\infty-\infty$ & $\ldots$ & $-\cdots$ & $\therefore---\cdots--$ & $-\cdots-\infty$ & $\ldots-\ldots$ \\
\hline 2 & $183.8 \mathrm{f}$ & 850 & 0 & 21731 & .1687158 .9 & 1120076 & 3605 \\
\hline 0 & 3.19 & 0 & 0 & 1142 & 29277.6 & 0 & 0 \\
\hline 0 & 10.82 & 3 & 0 & 972 & 99331.9 & 3363 & 65 \\
\hline 0 & $5 ? .53$ & 8 & 0 & 3371 & 528079.2 & 10837 & 650 \\
\hline 0 & 6.75 & 0 & 0 & 683 & 61963.3 & 0 & $0^{\circ}$ \\
\hline 0 & 11.94 & 2 & 1 & 1205 & 109598.2 & 2247 & 5354 \\
\hline 1 & 170.66 & 235 & 0 & 11075 & 1566530.4 & 309431 & 4231 \\
\hline
\end{tabular}


$08.27>81$

\section{NUCLEAR UNITS 1971-1980}

SELECTED NUILEAR UNITS NO OF SYSTEMS 37 NO OF UIITS

UNIT
STATISTIES

SER UICE HUURS

SERYICE FACTOR-Y

SERYICE FACTOR-\%
AVAILABLE HOURS

CAPACITY FACTOR-:

OUTPUT FACTOR-\%

EQUIV F.O.R.-\%

SCHEDLILEO OUIT RATE-X

FORCED OUT RATIO-X

F.O. INCIDENT RATE-Y

EQUIY AYAILABILITY-\%

CAIJE
CONE
REACTOR
TUPEIHE
COND.
REGUL.
GEN.
OTHER
UNIT

$69 N O$ OF UNIT YEAFS 421

\begin{tabular}{ccc} 
FOREED & OPERATING & MEAN TIME BETWEEN \\
OUTAGE RATE & AVAILABILITY & FULL FORCED OUTAGES \\
\hline CUMULATIVE-\% & CUMULATIVE-\% & CUMULATIVE \\
\hline 70 & 78.5 & 1776.44 \\
2.0 & 93.4 & +497.32 \\
0.4 & 97.9 & 16004.00 \\
1.4 & 97.3 & 43669.69 \\
0.7 & 97.3 & 20536.92 \\
2.3 & 96.4 & 3836.81 \\
12.8 & 72.4 & 850.17
\end{tabular}

FORCEO OUTAGES

CAUSE

COOE

REACTOR

REACTOR

TURE INE
CONO.

CONO,

GEN.

OTHER

UNIT

\begin{tabular}{rrrr} 
& UNIT YR AYG \\
NO & OUTAGE & MAN & HPS \\
OCC & HOUPS & HOLFS & HAIT \\
\hline 5 & 449.44 & 2351 & 0 \\
2 & 127.18 & 4460 & 7 \\
1 & 26.50 & 36 & 0 \\
0 & 37.07 & 326 & 0 \\
0 & 47.19 & 8 & 0 \\
2 & 141.48 & 327 & 0 \\
10 & 873.86 & 7507 & 7
\end{tabular}

$10 \quad 873.86$

10
006
1939
789
221
72
172
925
4173

Planined outales

CAUSE

- COOE

REACTOR

TURB INE

COND.

REGUL.

- GEN.

OTHER

UNIT

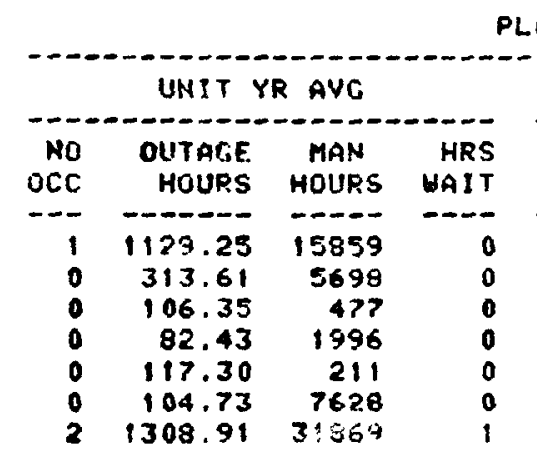

Cumulative

\begin{tabular}{rrr}
$\begin{array}{r}\text { OUTAGE } \\
\text { HOURS }\end{array}$ & \multicolumn{1}{c}{ MOUPS } & HOURS \\
WAIT \\
189212.7 & 51717 & 103 \\
53543.3 & 98109 & 2817 \\
11158.0 & 796 & 0 \\
36656.8 & 8162 & 16 \\
19865.8 & 175 & 50 \\
59564.7 & 7193 & 4 \\
370001.5 & 155156 & 2990
\end{tabular}

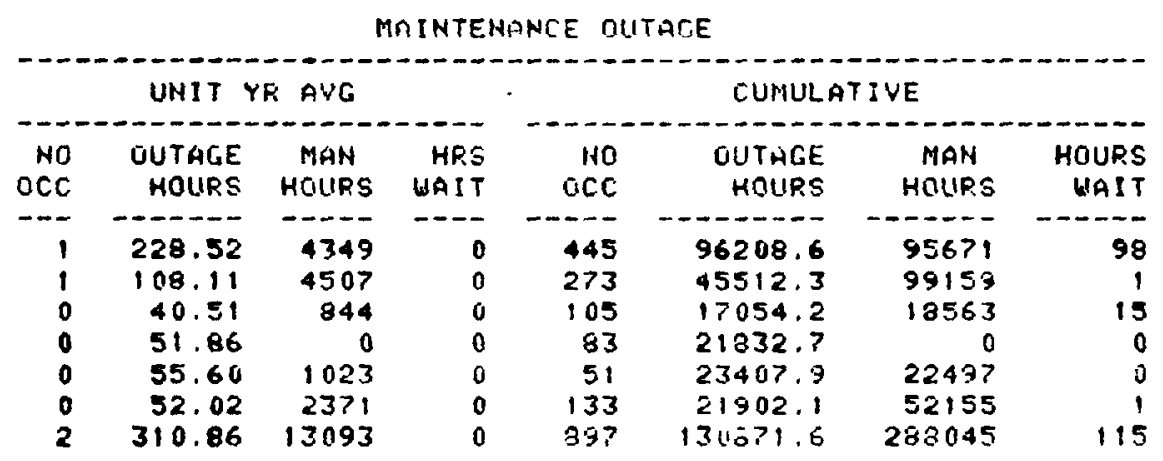

\begin{tabular}{rrrr} 
& \multicolumn{2}{c}{ CUMULATIVE } & \\
\hline HO & OUTAGE & MAN & HOURS \\
OCC & HOUFS & HOURS & WAIT \\
\hline 600 & 475413.8 & 348893 & 169 \\
184 & 132030.0 & 125351 & 88 \\
53 & 44772.8 & 10496 & 7 \\
82 & 34701.6 & 43910 & 8 \\
49 & 49383.1 & 4637 & 36 \\
72 & 44091.7 & 167824 & 79 \\
833 & 551050.5 & 701111 & 387
\end{tabular}

\begin{tabular}{|c|c|c|c|c|c|c|c|}
\hline \multicolumn{8}{|c|}{ MONCURTAILING OUTAGES } \\
\hline $\begin{array}{r}\text { NO } \\
\text { occ }\end{array}$ & $\begin{array}{r}\text { OUTAGE } \\
\text { HOURS }\end{array}$ & $\begin{array}{l}\text { MAN } \\
\text { HOUPS }\end{array}$ & $\begin{array}{r}\text { HRS } \\
\text { WAIT }\end{array}$ & $\begin{array}{r}\text { NO } \\
\text { OCC }\end{array}$ & $\begin{array}{r}\text { OUTAGE } \\
\text { - HOURS }\end{array}$ & $\begin{array}{c}\text { MAN } \\
\text { HOURS }\end{array}$ & $\begin{array}{l}\text { HOURS } \\
\text { WAIT }\end{array}$ \\
\hline$\cdots$ & $\ldots-\cdots$ & $\cdots$ & $\cdots$ & $\cdots-$ & $\because \ldots-\cdots$ & $-\cdots-\infty$ & $\cdots-\cdots$ \\
\hline $\begin{array}{l}3 \\
0\end{array}$ & $\begin{array}{r}239.56 \\
98.36\end{array}$ & $\begin{array}{r}65 \\
4\end{array}$ & $\begin{array}{r}18 \\
0\end{array}$ & $\begin{array}{r}1233 \\
172\end{array}$ & $\begin{array}{r}100856.2 \\
41409.2\end{array}$ & $\begin{array}{r}1433 \\
85\end{array}$ & $\begin{array}{r}7504 \\
0\end{array}$ \\
\hline 1 & 201.39 & 2 & 0 & 561 & 84786.1 & 43 & \\
\hline 0 & 18.79 & 0 & 0 & 49 & 7908.5 & 0 & 49 \\
\hline 0 & 19.32 & 2 & 0 & 45 & 8134.7 & 43 & 82 \\
\hline 1 & 116.83 & 40 & 3 & 373 & 49183.7 & 884 & 1335 \\
\hline
\end{tabular}


Analysis of the latest year's (1980) data for large coal and nuclear units (Tables 5 and 6) showed trends similar to the 1971-1980 fossilnuclear sample except that in 1980 the coal units experienced many more forced outages than the nuclear units (40 vs. 18 occurrences) which is evidenced by the mean time between forced outages (e.g., 723.30 hours for coal unit boiler vs. 1881.56 hours for nuclear reactor).

The Component Cause Code Report further delineates the causes of the plant outages via a subdivision of the major plant systems into over 800 components and subsystems. The reported data indicate that the causes of the outages are widespread, encompass all of the approximately 800 categories, and are not limited to a few subsystems or components.

The outages are divided into three categories: 1) Full Forced, 2) Forced Partial, and 3) Forced, Maintenance, Planned and Equivalent Partial Outages. Each of these categories is further broken into number of occurrences per year, number of hours per year, and number of hours per occurrence. Tables 7 through 12 provide the ten most significant causes of plant outage for each category for both nuclear and fossil units. A general observation of this data indicates that those components that tend to be the most frequent causes of plant outages are not usually the components responsible for causing the most delay. In addition, those outages caused by components resulting in the lengthiest outages tend to occur infrequently. 
FOSSIL UHIT'S PRIMARY FUEL-COAL 400 MN AND ABOYE YEAP 1980

SELECTED FOSSIL UHITS NO OF SYSTEMS 56 ND OF UHITS 164 ND OF UHIT YEAPS 164

UNIT

STATISTICS

\section{SERVICE HOURS}

SERYICE FACTOR-\%

AVA ILABLE HOURS

CAPACITY FACTOR -

OUITPUIT FACTOR-\%

EQUIY $F$, O R D

SCHEDULEO OUT RATE-\%

FORCED OUT RATIO-\%

F.O. INCIOENT RATE-\%

EQUIY AYAILABILITY-\%

\begin{tabular}{|c|c|c|}
\hline & FORCED & OPERATING \\
\hline & OUTHEE RATE & AVAILABILITY \\
\hline $\begin{array}{l}\text { CALISE } \\
\text { CODE }\end{array}$ & CUMULATIVE-\% & CUMULATIVE-\% \\
\hline$\ldots$ & 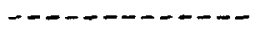 & $---m-m--\infty-\infty$ \\
\hline BOILER & 7.7 & 83.0 \\
\hline TUP.BINE & 2.2 & 91.9 \\
\hline CONE. & 0.4 & 99.3 \\
\hline GEN. & 0.5 & 96.9 \\
\hline OTHEF & 1.6 & 97.0 \\
\hline UNIT & 11,7 & 75.9 \\
\hline
\end{tabular}

MEAN TIME BETWEEH

FULL FORCEU OUITALES

723.30
2850.13
10131.50
3954.94
2559.03
429.59

FORCED OUTAGES

\begin{tabular}{|c|c|c|c|c|c|c|c|}
\hline & UNIT & R AVE & & & CUMUL & IVE & \\
\hline $\begin{array}{l}\text { NO } \\
\text { DCC }\end{array}$ & $\begin{array}{r}\text { OUTAGE } \\
\text { HOURS }\end{array}$ & $\begin{array}{l}\text { MAN } \\
\text { HOUPSS }\end{array}$ & $\begin{array}{r}\text { 4RS } \\
\text { WAIT }\end{array}$ & $\begin{array}{l}\text { NO } \\
\text { OCE }\end{array}$ & $\begin{array}{l}\text { OUTAGE } \\
\text { HOURS }\end{array}$ & $\begin{array}{l}\text { YALA } \\
\text { HOUFS }\end{array}$ & $\begin{array}{r}\text { HOUPS } \\
\text { WHAT }\end{array}$ \\
\hline-- & 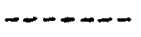 & $\ldots-$ & $\ldots$ & $-\cdots$ & $n-m-n$ & 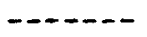 & $\ldots-\cdots$ \\
\hline 12 & 537.89 & 20230 & 0 & 1913 & 58214.7 & 20230 & 0 \\
\hline 0 & 0.27 & 0 & 0 & 8 & 43.6 & 0 & 0 \\
\hline 3 & 140.91 & 0 & 0 & 486 & 23108.0 & 0 & 0 \\
\hline 1 & 25.19 & 0 & 0 & 136 & 4130.7 & 0 & is \\
\hline 0 & 2.00 & 0 & 0 & $?$ & 328.6 & 0 & 0 \\
\hline 1 & 35.08 & 0 & 0 & 154 & 5753.3 & 0 & 0 \\
\hline 3 & 103.42 & 0 & 0 & 521 & 16961.3 & 0 & 0 \\
\hline 20 & 844,76 & 20230 & 0 & 3230 & 138541,1 & 20230 & 0 \\
\hline
\end{tabular}

PLANMED OUTAGES

\begin{tabular}{|c|c|c|c|c|c|c|c|}
\hline \multicolumn{4}{|c|}{ UNIT YR AYG } & \multicolumn{4}{|c|}{ CUNULATIVE } \\
\hline $\begin{array}{r}\text { NO } \\
0 C C\end{array}$ & $\begin{array}{c}\text { OUTAGE } \\
\text { MOURS }\end{array}$ & $\begin{array}{l}\text { MAN } \\
\text { HOURS }\end{array}$ & $\begin{array}{l}\text { HRS } \\
\text { WAIT }\end{array}$ & $\begin{array}{l}\text { NO } \\
\text { OCE }\end{array}$ & $\begin{array}{l}\text { UUTAGE } \\
\text { HOURS }\end{array}$ & $\begin{array}{l}\text { MAN } \\
\text { HOURS }\end{array}$ & $\begin{array}{l}\text { HUUPSS } \\
\text { WAIT }\end{array}$ \\
\hline-- & $--\infty-\infty$ & $-\cdots$ & $-\cdots$ & $--\infty$ & 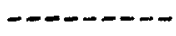 & $m-\cdots$ & $-\cdots-$ \\
\hline 1 & 682.07 & 1656 & 0 & 172 & 111859.8 & 1656 & 0 \\
\hline 0 & 13.10 & 0 & 0 & 5 & 2147.8 & 0 & 0 \\
\hline 1 & 427.81 & 480 & 0 & 98 & 70160.8 & 480 & - \\
\hline 0 & 97.16 & 360 & 0 & 20 & 15934.7 & 360 & 0 \\
\hline 0 & 29.72 & 0 & 0 & 10 & 4874.3 & 0 & 0 \\
\hline 0 & 193.45 & 160 & $\mathbf{0}$ & 30 & 31726.5 & 160 & 0 \\
\hline 0 & 76.50 & & 0 & 20 & 12545.8 & 0 & 0 \\
\hline 2 & 968.88 & 2656 & 0 & 284 & 158896.6 & 2656 & 0 \\
\hline
\end{tabular}

MaINTENANEE OUTAGE

\begin{tabular}{|c|c|c|c|c|c|c|c|}
\hline \multicolumn{4}{|c|}{ UNIT YR AYG } & \multicolumn{4}{|c|}{ CUMULATIVE } \\
\hline no & OUTAGE & MAH & HFis & $N O$ & OUTHGE & MHH & HOUFS \\
\hline ces & HuUf: & HOUES & WAIT & orr & HillfFis & Hnith:s & $W .21 T$ \\
\hline 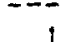 & 21370 & 0 & 0 & 229 & 350472 & 0 & r \\
\hline 0 & 5.58 & 0 & $a$ & 12 & 915.0 & ij & \\
\hline i & 114.93 & 0 & 0 & 178 & 18249.2 & 0 & 0 \\
\hline 0 & 13.25 & 0 & 0 & 21 & 2172.8 & 0 & 0 \\
\hline 0 & 16.53 & 0 & 0 & 9 & 2710.3 & 0 & \\
\hline 0 & 31.24 & 0 & 0 & 30 & 5123.3 & 0 & \\
\hline 0 & 66.08 & a & 0 & 63 & 10837.8 & ij & \\
\hline 3 & 252.05 & 0 & 0 & 479 & 413.36 .7 & $u$ & \\
\hline
\end{tabular}

NOHCURTHILING OLTTALES

\begin{tabular}{|c|c|c|c|c|c|c|c|}
\hline \multicolumn{4}{|c|}{ UNIT YR AYI } & \multicolumn{4}{|c|}{ CUPIULATIVE } \\
\hline $\begin{array}{l}\text { NO } \\
\text { OCC }\end{array}$ & $\begin{array}{l}\text { OUTAGE } \\
\text { HOURS }\end{array}$ & $\begin{array}{l}\text { MAN } \\
\text { HOURS }\end{array}$ & $\begin{array}{l}\text { HFS } \\
\text { WRIT }\end{array}$ & $\begin{array}{r}\text { NO } \\
\text { OCC }\end{array}$ & $\begin{array}{l}\text { OUTACE } \\
\text { HOURS }\end{array}$ & $\begin{array}{l}\text { MAN } \\
\text { HOURS }\end{array}$ & $\begin{array}{l}\text { HEURS } \\
\text { WPIT }\end{array}$ \\
\hline- & $\cdots \cdots$ & $\ldots-\infty$ & $-\infty$ & $\cdots$ & 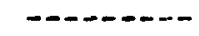 & 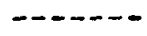 & $--\infty-\infty$ \\
\hline 9 & 617.07 & 0 & 0 & 1511 & .101200 .2 & 0 & \\
\hline 2 & 34.08 & 0 & 0 & 277 & . $\quad 5720.7$ & 0 & \\
\hline 0 & 6.49 & 0 & 0 & 18 & 1064.4 & 0 & \\
\hline 1 & 98.90 & 0 & 0 & 94 & 16219.3 & 0 & \\
\hline 0 & 22.26 & 0 & 0 & 21 & 3650.4 & 0 & \\
\hline 0 & 0.05 & 0 & 0 & 2 & 8.6 & $\dot{0}$ & \\
\hline 3 & 361.37 & 0 & 0 & 414 & 59264.4 & 0 & \\
\hline
\end{tabular}


ALL NUCLEAR UNITS FOR YEAR 1980

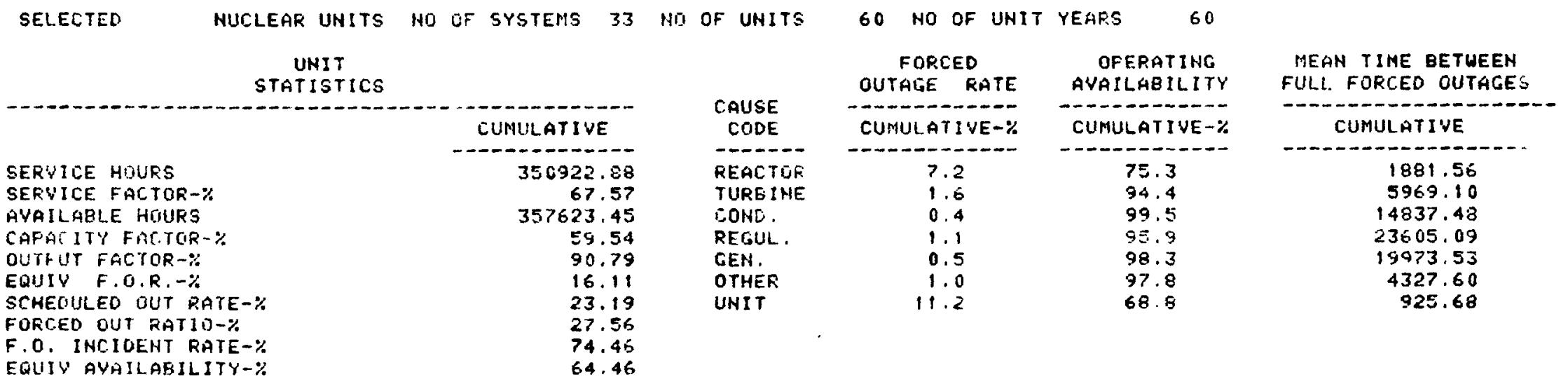

FORTED OUTAGES

CAUSE

COOE

\section{REarto}

REACTOR

TUREINE

CONE.

REGIJL.

GEN.

OTHER

UNIT

\begin{tabular}{rrrr} 
& UNTT YR AVG \\
HO & OUTAGE & MAN & MPS \\
OCC & HOURS & HOUKS & WAIT \\
\hline 5 & 460.10 & 55 & 0 \\
1 & 97.38 & 0 & 39 \\
1 & 24.67 & 0 & 0 \\
0 & 66.91 & 8 & 0 \\
0 & 33.05 & 0 & 1 \\
2 & 60.76 & 0 & 0 \\
9 & 742.36 & 63 & 40
\end{tabular}

PlanNed OUTAGES CUMULATIVE

\begin{tabular}{rrrr} 
HO & OUTAGE & MAN & HOUPS \\
OCE & HOURS & HOUPS & WAIT \\
\hline 275 & 27605.8 & 55 & 0 \\
86 & 5842.8 & 0 & 2322 \\
34 & 1479.9 & 0 & 0 \\
21 & 4014.6 & 8 & 5 \\
25 & 1982.8 & 0 & 50 \\
119 & 3645.3 & 0 & 0 \\
560 & 44571.5 & 53 & 2380
\end{tabular}

44571.5

2380

\begin{tabular}{rrrr}
\multicolumn{2}{c}{ CUMULATIVE } \\
NO & OUTAGE & MAN & HOURS \\
OCC & HOURS & HOURS & WAIT \\
\hline 74 & 92195.5 & 19373 & 16 \\
23 & 22149.7 & 0 & 0 \\
1 & 196.0 & 0 & 0 \\
16 & 12017.9 & 0 & 0 \\
5 & 6278.8 & 0 & 0 \\
9 & 6330.1 & 19138 & 24 \\
101 & 107081.4 & 38561 & 40
\end{tabular}

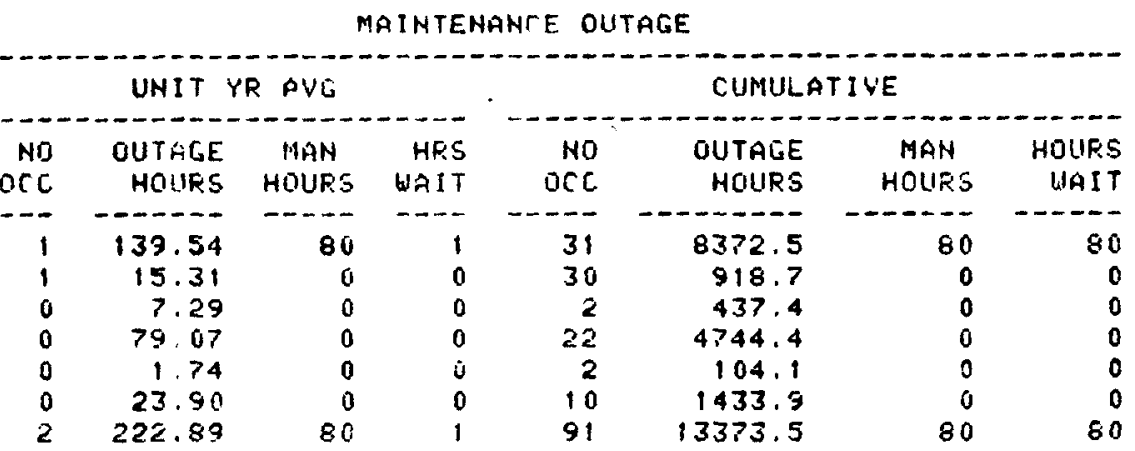

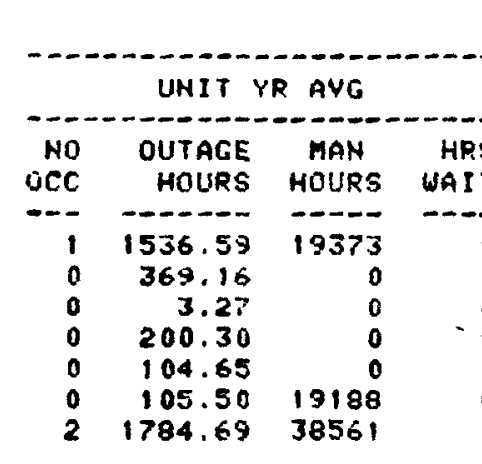

10

07081.4

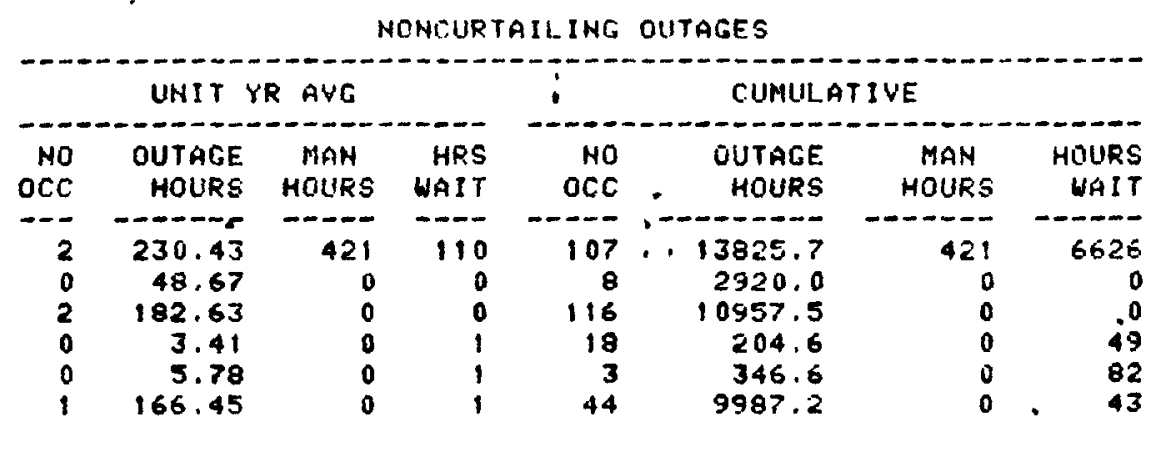


Table 7

Significant Causes of Plant Outages

$$
\begin{aligned}
& \text { Nuclear } \\
& 1971-1980
\end{aligned}
$$

Full Forced Outages

Avg. No.

\section{Cause}

Occ/Unit Yr

Reactor Protec. I $\& C$
Turbine Control

.65

.57

Steam Generator

Coolant Recirc. Pumps/Drives

Operating Error

Coolant System Valves/Piping

Control Rods \& Drives

.51

.47

.43

Turbine Control \& Stop Valves .36

Boiler Feed Pump Drive - $\quad .33$

Steam Turbine

Other, General
Avg.

Hrs/Unit Yr

$$
\begin{array}{r}
101.25 \\
75.92
\end{array}
$$

Coolant Recirc. Pumps/

Drives

Maintenance Error

NRC Order - Safety

Turbine Buckets or Blades

Coolant System Valves/

$$
\text { Piping }
$$

Control Rods \& Drives

Reactor, Miscellaneous

Turbine Vibration

other, General
Avg. Dur.

Hrs/Out.

2212.76

1649.58

1323.46

889.93

779.95

735.22

648.57

599.86

521.03

513.64 
Table 8

Significant Causes of Plant Outages

Nuclear

1971 - 1980

Forced Partial Outages

Avg. No.

Cause

Other, General

Condenser, General

Occ/Unit Yr

Reactivity Limitation

4.66

2.68

2.50

2.45

1.36

1.10

Reactor, Miscellaneous

Coolant Recirc. Pumps/Drives

Condenser Cleaning

Cooling Towers

Control Rods \& Drives
.91

.86
Avg.

Cause

Reactivity Limitation

Fuel Assembly

Radioactivity Discharge

Turbine Buckets/Blades

Other, General

Reactor Internals

Condenser Tubing

Reactor, Miscellaneous

Coolant Recirc. Pumps/Drives

Steam Generator
Hrs/Unit Yr

58.83

44.14

18.49

14.73

13.84

13.33

10.51

8.94

.79

8.66

8.41

Fue1 Supply Limitation

Hrs/Out.

Radioactivity Levels/Discharge

Reactor Internals

e Buckets or Blades

Turbine Shaft/Bearings $\quad 149.40$

Boiler Feed Pump Drive - $\quad 68.60$

Electric Motor

ECCS Low Pressure

RHRS

Steam Generator

NRC Order - Safety

53.67

46.98 
Table 9

Significant Causes of Plant Outages

$$
\begin{gathered}
\text { Nuclear } \\
1971-1980
\end{gathered}
$$

Forced, Maintenance, Planned, and Equivalent Partial
Avg. No.

\section{Cause}

Other, General

Reactivity Limitation

Condenser Tube Failure

Fuel Assembly

Condenser Cleaning

Reactor, Miscellaneous

Recirc. Pumps and Drives

Reactor, General

Turbine Moisture Removal
Turbine Control/Stop Valves

\section{Occ/Unit Yr}

5.35

3.35

3.10

3.03

2.29

2.07

1.91

1.80

1.71

1.63

\section{Cause}

Refueling

Turbine, General

Steam Generator

Other, General

Reactor, General

Generator, General

Condenser, General

Recirc. Pumps and Drives

NRC Modification - Safety

NRC Order - Safety
Avg.

Hrs/Unit Yr

912.49

363.81

204.75

175.23

149.46

133.80

124.28

107.92

88.45

73.28
Avg. Dur.

Hrs/Out.

1649.58

1302.24

1165.51

886.75

722.18

632.36

544.58

487.79

482.04

432.33 
Table 10

Significant Causes of Plant Outages

Fossil

$1971-1980$

Ful1 Forced

Avg. No.

Cause Occ/Unit Yr

\section{Water Walls}

Superheater

Boiler Controls

Economizer

Boiler, General

衿 Turbine Vibration

Turbine Control and Stop

$$
\text { Valves }
$$

Generating Tubes

Turbine Control

Fuel Handling Equipment

1.58
1.08
.60
.52
.42
.30
.21
.18
.18
.17

Avg.

Hrs/Unit Yr

Water Walls
Superheater
Reheater - First
Economizer
Boiler, General
Turbine, Vibration
Turbine Buckets or Blades
Generating Tubes
Turbine Lube Oil System
Turbine, General

93.86

60.26

25.23

22.92

21.40

20.48

15.19

13.99

12.83

12.53
Avg. Dur.

Hrs/Out.

5726.29

3865.12

1209.54

942.37

935.72

757.80

745.80

572.18

550.97

534.42

Turbine Blade Fouling

Stator Core

Turbine Water Induction

Rotor Windings
Turbine Wheels/spindles

Turbine Dumny Rings

$\begin{array}{lr}\text { Parts Unavailability } & 5726.29 \\ \text { Turbine Shaft } & 3865.12 \\ \text { Rotor Windings } & 1209.54 \\ \text { Turbine Wheels/Spindles } & 942.37 \\ \text { Turbine Dummy Rings } & 935.72 \\ \text { Scrubber Thickeners } & 757.80 \\ \text { Turbine Buckets or Blades } & 745.80 \\ \text { Turbine Blade Fouling } & 572.18 \\ \text { Stator Core } & 550.97 \\ \text { Turbine Water Induction } & 534.42\end{array}$


Table 11

\section{Significant Causes of Plant Outages}

Fossil

$$
1971-1980
$$

Forced Partial

Avg. No.

\section{Cause}

\section{Pulverizers}

Wet Coal

Poor Quality Fuel

Fuel

Boiler Water Condition

Furnace Slagging

Coal Pulverizer Feeders

Induced Draft Fans

Feedwater Heaters - Leaking

Condenser Cleaning
Occ/Unit Yr

8.01

2.65

2.08

2.05

1.81

1.57

1.32

1.32

1.25

1.04
Avg.

Hrs/Unit Yr

Pulverizers

26.33

Feedwater Heaters - Leaking 17.52

Induced Draft Fans $\quad 13.45$

Forced Draft Fans

Boiler Feed Pumps, General 10.34

Boiler Feed Pump 9.84

Wet Coa1

Poor Quality Fue1

Boiler Water Condition

Boiler, Miscellaneous
7.43

7.22

6.70

6.60
Cause

Turbine Diaphram

Turbine Piping

order to Investigate

Industrial Safety Problems

Turbine Dummy Rings

Turbine Shell Leaks

Turbine Water Induction

Turbine Nozzle Bolting

Turbine Nozzle and Blocks

Boiler Feed Pump Drive - Main Shaft

Turbine Seal Leaks
Avg. Dur.

Hrs/Out.

113.54

111.21

63.40

56.55

55.51

50.16

47.40

41.75

27.68

26.56 
Table 12

Significant Causes of Plant Outages

Fossil

$1971-1980$

Forced, Maintenance, Planned and Equivalent Partial

Avg. No.

Occ/Unit Yr

10.12

3.66

2.72

2.43

2.15

2.12

2.07

2.00

1.79

1.70
Avg. Hrs/Unit Yr

499.52

381.46

238.92

165.84

135.09

118.97

71.75

69.69

68.32

37.12
Turbine Inspe
Pulverizers
Cause

Turbine Shaft

Parts Unavailability

Turbine, Miscellaneous

Turbine Inspection

Generator, General

Turbine, General

Generator Inspection

Turbine Dummy Ring

Rotor Windings

Water Induction
Avg. Dur.

Hrs/Out.

3865.12

1284.62

908.40

664.34

616.19

468.04

468.03

466.52

488.23

409.71 
Analysis of the most significant nuclear Full Forced outages indicates that problems with the steam supply occurred most frequently; however, the problems that were the lengthiest primarily involved NRC regulatory order. On an annual hours per year basis, steam generator problems were the most troubling.

Forced Partial outages of the nuclear plants tended to occur more frequently than Full Forced outages but were of much shorter duration. As shown in Table 9, when planned outages and maintenance are also considered, the most significant outage in annual hours per year is due to refueling ( 912.49 hours/year). Also evident is the wide diversity of outage causes as well as the high incidence of regulatory-imposed outages.

Analysis of the most significant fossil Full Forced outages indicates that, like the nuclear units, the most frequent problems occurred with the steam supply. However, unlike nuclear, the lengthiest problems were primarily related to the turbine-generator. On an annual hours per year basis, problems with the steam supply were the most troubling.

As with the nuclear units, Forced Partial outages of the fossil units tended to occur more frequently and were of shorter duration. Problems with fuel were most common and problems with turbines were the lengthiest. When planned outages and maintenance are also considered, the diversity of the areas of concern is readily apparent. 
Because of the wide diversity of nuclear and fossil plant outage causes, the overriding implication of the data is that, in order for plant availability to significantly improve, progress in component reliability should not simply be focused on only improving a few components. The cost of such improvement may yield only marginal gains in total plant availability. Instead, the most economical approach would be to first consider plant availability vs. customer electricity demand pattern, this in light of the individual utility's mix of generation technologies. Then, the interplay between the number of outage occurrences in a year and the number of hours per outage must be weighed, as well as the marginal cost of plant downtime vs. the cost of additional component reliability. Furthermore, one must also weigh the cost of additional preventive maintenance and its associated downtime vs. the expected reduction in forced outages. Such evaluations will identify and pinpoint the degree to which components need to be improved. 


\section{Definitions}

\section{Equipment Definitions}

1. Component - Part within a "major equipment" group, such as: superheater tube, governor, buckets, boiler feed pump.

2. Header Unit - Unit in which a single boiler is not solely and independently connected to a single given turbine generator, (e.g. single or multiple boiler(s) are connected to multiple or single turbine generator(s)).

3. Major Equipment - Major group of equipment within a unit. such as: boiler, reactor, generator, steam turbine, condenser.

4. Major Equipment Abbreviations Used Include -

BOll.F. $=$ Steam Generator

TURBINE = Turbine

REACTOR = Steam Supply System-Nuclear

COND $=$ Condenser

GEN = Generator (Electrical)

REGUL = Regulatory

SCRBBRS $=\mathrm{SO}_{2}$ Scrubbers

GAS TUR = Gas Turbine

JET ENG = Jet Engine

DIESEL. = Diesel Engine

OTHER = Balance of Plant

UNIT = Total unit including all components

5. Maximum Dependable Capacity (MDC) - The dependable main-unit capacity winter or summer, whichever is smaller.

6. Non-header Unit - Unit in which a single boiler is connected solely and independently to a given turbine-generator. 


\section{Operation and Outage Definitions}

1. Available - The status of a unt or major piec e of equipment which is capable of service whether or not it is actually in service

2. Base Loading - When a unit is generally run at or near rated output

3. Cranking Loading - When a unit is generally shut down on standby for auxiliary power dunng emergency

4. Cycling Loading - When a unit is generally run but at a load which vanes widely with system demand

\section{Economy Outage - (See Reserve Shutdown)}

6. Forced Outage - The occurrence of a component fallure or other condition which requires that the unit be removed from service immediately or up to and including the very next weekend

7. Forced Partial Outage - The occurrence of a component falure or other condition which requires that the load on the unit be reduced $2 \%$ or more immediately or up to and including the very next weekend

8. Maintenance Outage - The removal of a unit from servce to perform work on specific components which could have been postponed past the very next weekend This is work done to prevent a potential forced outage and which could not be postponed from season to season

9. Non-curtailing Equipment Outage - The removal of a specific component from service for repair which causes no reduction in unit load or a reduction of less that $2 \%$
10 Non-operating Equipment Test - A scheduled test or required operation of a back up system which is not normally operatıng

11. Outage Cause - A component falure, preventive maintenance or other condition which requires that the unit or a component be taken out of service or run at reduced capacity

12. Peak Loading - When a unit is generally shut down and is run only during high demand penods

13. Planned Outage - The removal of a unit from service for inspection and / or general overhaul of one or more major equipment groups This is work which is usually scheduled well in advance (e g annual boiler overhaul, five year turbıne overhaul)

14. Reserve Shutdown - The removal of a unit from service for economy or similar reasons This status continues as long as the unit is out but avallable for operation

15. Scheduled Partial Outage - The occurrence of a component failure or other condition which requires that the load on the unit be reduced $2 \%$ or more but where this reduction could be postponed past the very next weekend

16. Scheduled Outages - Scheduled outages are a combination of noncurrent Maintenance and Planned Outages

17. Unavailable - The status of any major piece of equipment which renders it inoperable because of the fallure of a component work being performed or other adverse condition 


\section{Time Definitions}

1. Available Hours (AH) - The time in hour dining which a umit or major equipment is available: $\mathrm{SH}+\mathrm{RSH}$

2. Cumulative - A summary over the period being considered by the report.

3. Demand Period - The time interval each day which is the period of maximum demand on a particular system.

4. Economy Outage Hours (See Reserve Shutdown Hours) (TEOH) The theoretical value of Economy Outage Hours (TEOH) is the difference between Available Hours and Service Hours.

5. Equivalent Forced Outage Hours (EFOH) - [Forced Partial Outage Hours x Size of Reduction / MDC]

6. Equivalent Scheduled Outage Hours (ESOH) - [Scheduled Partial Outage Hours x Size of Reduction / MDC]

7. Forced Outage Hours (FOH) - The time in hours during which a unit or major equipment was unavailable due to a Forced Outage.

8. Forced Partial Outage Hours (FPOH) - The time in hours during which a unit or major equipment is unavailable for full load due to a Forced Partial Outage.

9. Hours Waiting (HW) - That portion of time for any outage during which no work could be performed. This includes time for cooling down equipment and shipment of parts. This is time that could not be affected by a change in work schedule or the number of men worked.
10. Maintenance Outage Hours $(\mathbf{M O H})$ - The time in hours during which a unit or major equipment is unavailable due to a maintenance outage.

11. Period Hours $(\mathbf{P H})-$ The clock hours in the period under consideration. (Generally one year.)

12. Planned Outage Hours (POH) - The time in hours during which a unit or major equipment is unavailable due to a planned outage.

13. Reserve Shutdown Hours (RSH) - Reserve shutdown duration in hours.

14. Scheduled Partial Outage Hours (SPOH) - The time in hours during which a unit or major equipment is unavailable for full load due to a scheduled partial outage.

15. Scheduled Outage Hours (SOH) - The time in hours during which the unit was uhavailable due to nonconcurrent maintenance or planned outage work being performed.

16. Service Hours (SH) - The total number of hours the unit was actually operated with breakers closed to the station bus.

17. Unit Years (UY) - This term is the common denominator used to normalize data from units of the same type with different lengths of service. The following example contains 20 UY of experience from 4 units.

\begin{tabular}{lccccc} 
Unit & & & \multicolumn{3}{r}{ TOTAL } \\
Years in Service & A & B & C & D & 4 \\
& 8 & 3 & 7 & 2 & 20
\end{tabular}

18. Work (Manhours Worked) (MH) - The total number of manhours worked on or off site to accomplish repairs. 


\section{Equations}

1. Average Forced Outage Duration - (Summation of $\mathrm{FOH}) /($ Number of Forced Outages)

2. Capacity Factor - CF- [(Total Gross Generation in MWHRs) / (PH $\mathrm{x}$ $\mathrm{MDC})] \times 100\left(X_{3}\right)$

3. Component Outage Severity Index - The average number of forced outage hours of a specific component per incident

4. Equivalent Availability Factor -EAF$[\mathrm{AH}-(\mathrm{EFOH}+\mathrm{ESOH})] / \mathrm{PH} \times 100(\%)$

5. Equivalent Forced Outage Rate (for each forced partial outage, an equivalent full load outage duration is calculated to include the effect of partial as well as full forced outages on the forced outage

6. Forced Outage Incident $-[$ (Forced Incidents) / (Forced + Maintenance + Planned Incidents)] $\times 100(\%)$

7. Forced Outage Rate $-\mathrm{FOR}-[\mathrm{FOH} /(\mathrm{SH}+\mathrm{FOH})] \times 100(\%)$

8. Forced Outage Ratio - $[\mathrm{FOH} /(\mathrm{PH}-\mathrm{AH})] \times 100(\%)$

9. Mean Duration of Starting Failure Outage - (Starting Fallure Outage Hours) / (Number of Startıng Fallures)

10. Mean Time Between Full Forced Outages - (Summation of PH) / [(Number of Full Forced Outages) +1$]$

11. Operating Availability $-\mathrm{AF}-[\mathrm{AH} / \mathrm{PH}] \times 100(\%)$

12. Output Factor - OF- [(Total gross generation in MWHRs) / (SH x MDC) ] $\times 100\left(x_{1}\right)$

13. Service Factor $-\mathrm{SF}-[\mathrm{SH} / \mathrm{PH}] \times 100(\%)$

14. Scheduled Outage Rate $-\mathrm{SOR}-[\mathrm{SOH} /(\mathrm{SH}+\mathrm{SOH})] \times 100($ \%)

15. Starting Failure Ratio - (Number of Starting Falures) / (Total Number of Starting Attempts) 
B. Update on TMI-2 Decontamination Process

In the previous issue of UPDATE ${ }^{-1 /}$, we reported on the anticipated operation of the Submerged Demineralizer System (SDS) for decontaminating water in the TMI-2 containment building. In a notice put out November 16,1982 , GPU Nuclear stated that the water leve1 in the containment building has dropped from about $8 \frac{1}{3}$. feet to about $5 \frac{1}{2}$ feet since the SDS began operating September 23 .

The SDS was built to process some 600,000 gallons of water that collected in the basement of the containment building during the Unit 2 accident in March, 1979.

The SDS has been processing almost constantly since it began operation, and has been shut down only for routine maintenance and to change containers of the Zeolite materials that are absorbing better than 99 percent of the radioactive Cesium and Strontium in the water.

GPU announced October 22 that it is beginning an accelerated entry program for research and development of decontamination techniques inside the damaged Unit 2 reactor building at Three Mile Island. Under the plan, Unit 2 reactor building entries-previously scheduled on a one-per-month basis--will increase to as many as two entries a week, starting in November and continuing through January 1982.

1/ May/June 1981 UPDATE, page 45. 
There will be approximately 17 entries in all, involving a total of 290 manhours inside the reactor building. In comparison, the previous entry program was conducted over a 14-month period, using 200 manhours and 16 trips within the reactor building.

The new entries will provide opportunities to monitor and assess the effectiveness of cleanup technology being tested by TMI personnel. As an added benefit, the program will reduce radiation levels within the reactor building, allowing workers to stay inside for longer periods of time to perform maintenance, cleaning, refueling, and additional data acquisition.

In one experiment, technicians will wear a new piece of protective clothing called an "ice vest". Designed to reduce heat stress, it was developed by Pennsylvania State University, and tested by the Electric Power Research Institute and GPU Nuclear's Industrial Safety and Health Department.

The "vest" is a shirt made of insulating material. Attached to the side of the garment are many small ice packets. Tests showed that the "ice vest" provides an effective means of combating the problem of heat stress, and therefore lengthens the time a worker can spend inside the reactor building.

During the cleanup effort, technicians will hose down floors and walls in an attempt to remove a substantial portion of the radioactive contamination left in the wake of the March 28, 1979 accident at Unit 2 . 
Technicians must first remove extraneous material, protect equipment which might be damaged by the water, bring in water supply lines and extra electrical service, and carry in othex equipment necessary for the decontamination phase.

EPICOR-II was used to treat approximately 500,000 gallons of water that accumulated in the Unit 2 auxiliary building after the accident, and it also acts as a final "polisher" for the reactor building water. SDS is now working to decontaminate the water in the basement of the reactor building.

GPU Nuclear will use approximately 55,000 to 60,000 gallons of water processed by the Submerged Demineralizer System and the EPICOR-II treatment system. Using low-pressure hot water, the hose teams will clean the polar crane and flush the second and third floors of the building. The process will then be repeated on the two floors using high-pressure hoses. Workers plan to "squeegee" the water into floor drains which empty into the basement sump. There it will await processing through SDS and EPICOR-II. A more thorough scrubbing of the building surfaces will take place later.

In addition to the decontamination work, a hoist-type device will be installed on the reactor building's polar crane to give workers better access for repairs. With the lift in place, technicians will be able to go from the second to third levels, avoiding a stairwell that is an area of high radiation. 


\section{(.) Utility Briefs}

1. Breeder Reactor Corporation, "Support for Clinch River" In a Breeder Reactor Corporation (BRC) bulletin released November 6, 1981, America's electric utility systems reaffirmed their support and financial commitment to the Clinch River Breeder Reactor Project.

"At a meeting (November 6) of the Board of Directors of BRC (BRC represents 753 utilities nationwide), immediate release of up to $\$ 22$ million of available utility funds to the Department of Energy was authorized for application to the project. The funds will be made available upon favorable completion of the Congressional appropriation process for fiscal year 1982 permitting the project to move forward in accordance with government-industry agreements first executed in 1972. In addition to the release of these funds, the utilities plan to spend an estimated $\$ 8$ million for project operations during fiscal year 1982 .

"Speaking at the meeting, Deputy Secretary of Energy Kenneth Davis emphasized the importance of the project and described the action taken by DOE to move it forward aggressively to completion. He pointed out that accelerating construction of the project could save taxpayers several hundred million dollars. Davis noted that, in a letter to BRC, Secretary of Energy James B. Edwards said, 'The project continues to be a key element in the development of liquid metal fast breeder reactor technology and a vital step in fulfilling DOE's nuclear 
mission.' He termed utility support 'extremely important' to moving the project ahead.

"BRC Chairman Thomas G. Ayers stated that the utilities will do their part to support the Administration's efforts to complete the project. According to Ayers, the breeder has the potential to produce energy equivalent to the entire world's reserves of oil merely by utilizing uranium already mined and stored as tailings at the Government's enrichment plants.

"Ayers said that the utility industry has already contributed approximately $\$ 113$ million to the Clinch River Project and has pledged a total of $\$ 257$ million to build and operate the nation's first large-scale demonstration breeder reactor in Oak Ridge, Tennessee. Ayers concluded, 'We believe the project is crucial to supplying the energy our nation and the American consumer will need in the next century.'

"Retiring Project Director Lochlin W. Caffey said that the design has been continuously updated and is at the forefront of worldwide breeder reactor development. The progress on the Clinch River plant to date has been significant despite a licensing embargo imposed by the previous Administration. According to Caffey, the design of the project is $86 \%$ complete with over 7,000 of the required 9,000 construction drawings already produced. The research and development borne by the project is over $95 \%$ complete. Virtually all of the major components have been ordered. About $\$ 250$ million worth of hardware has been completed and delivered. 
"Caffey added that over $\$ 1.1$ billion has already been invested in the Clinch River Project and about 3,500 people in 30 states and the District of Columbia are employed on project work. Plans for the start of construction are in place awaiting positive action from the recently reinstituted licensing review activities of the Nuclear Regulatory Commission."

2. Public Service Electric \& Gas Company, "Dedication of Salem Generating Station"

Public Service Electric \& Gas Company announced that, "Dedication ceremonies were held October 2 for the Salem Generating Station, a nuclear complex containing two large units capable of producing 2.2 million kilowatts of electricity--sufficient to supply a million homes.

"The station is the first nuclear generating facility to be built and operated by Public Service Electric and Gas Company (PSE\&G), New Jersey's largest utility, which serves threequarters of the population of the state.

"PSE\&G shares ownership and output of the station with three other utilities. PSE \&G and Philadelphia Electric Company each have a 42.59 percent interest, and Atlantic Electric Company and Delmarva Power \& Light Company each have 7.41 percent shares. "'During a recent week, 34 percent of the PSE\&G system load was supplied by nuclear generation--21.7 percent by the two Salem units', Robert I. Smith, PSE\&G Board Chairman said. 'In the same week', he said,' coal supplied 35 percent, 
gas 17 percent, purchased power 10 percent, and on1y 4 percent was provided by oil.'

"'The importance of nuclear generation really is impressive when you realize that the nuclear fuel cost is 42 cents per million BTU while the oil cost is $\$ 5.63$ per million,' Smith said.

"The station, on which work began in 1968, cost more than $\$ 1.3$ billion to construct. It is located on a 700 -acre tract on a peninsula known as Artificial Island on the eastern shore of the lower Delaware River in Salem County.

"The two nuclear units are pressurized water reactors supplied by Westinghouse Electric Corporation. Each has a capacity of approximately $1,100,000$ kilowatts. The first unit began commercial operation in 1977. The second is undergoing final testing with comnercial operation expected later this month.

"Start-up of the second unit was delayed by about two years as a result of a halt in the issuance of operating licenses by the Nuclear Regulatory Commission following the 1979 Three Mile Island accident in Pennsylvania."

3. Vermont Yankee Nuclear Power Corporation, "Vernon Plant Refueling and Maintenance"

A news release from Vermont Yankee stated, "At midnight on Friday October 16, the Vermont Yankee Nuclear Power Plant in Vernon, Vermont, is scheduled to begin its annual refueling/maintenance 
shutdown. The outage, granted by the New England Power Pool Committee, will last for approximately a seven week period.

"'This year's operation has been an exceptionally good one,' stated William F. Conway, President and Chief Operating Officer of Vermont Yankee Nuclear Power Corporation. 'Since startup in January, our Vernon plant has surpassed five major records for performance, including longest electrical run and largest electrical generating output. Our year-to-date capacity factor, in excess of $94 \%$, ranks Vermont Yankee as one of the Nation's finest nuclear generating facilities,' Conway added.

"Major tasks to be addressed during the outage by both Vermont Yankee employees and nearly 800 additional support personne1 include refueling of the 540-megawatt reactor, turbine/generator preventive maintenance, replacement of two feed water check valves, a major In-Service-Inspection and replacement of approximately 320 feet of stainless piping in the Reactor Water Clean-up System. Of special note is the reactor refueling where an additional $25 \%$ of the fuel cells will be replaced. This increased fuel replacement is being undertaken in anticipation of an extended operating run through 1982."

4. Pub1ic Service Indiana, "Nuclear Plant's Progress Gets a Lift" Public Service Indiana reported on November 4 that, "It had passed a milestone in the construction of its Marble Hill nuclear plant recently when a major dome section was lifted into place. 
The 150-ton ring is 140 feet in diameter and 20 feet tall.

The ring and a soon-to-be-installed cap will completely enclose one of two containment buildings, the structures which will house the two nuclear reactors at the site. Marble Hill's two generating units each will produce 1.13 million kilowatts of electricity. The first unit, to be completed in 1986, is now about 25 percent finished. The second unit, scheduled to begin producing power in 1987 , is about 10 percent complete. The nuclear plant will serve more than 800,000 customers of Public Service Indiana and the Wabash Valley Power Association, a group of 24 rural electric cooperatives. Despite rising construction costs, Marble Hill will still provide power more cheaply than a new coal-fired plant. A recent Nuclear Regulatory Commission inspection report praised the quality assurance program at Marble Hill, saying that site managers have '...a thoroughly comprehensive commitment to quality construction and engineering."

5. Commonwealth Edison Company, "Switching to Nuclear" On November 30, Energy Users News (EUN) reported on Commonwealth Edison's decision to replace oil-fired electric power with nuclear power during early 1982.

"The Commonwealth Edison (ComEd) Company here will close one of its two oil-fired power generating stations and switch to the increased use of nuclear power during the first half of 1982, a move that the company claims will ultimately save its commercial and industrial customers 17 percent per kilowatt-hour (kwh) in electricity costs. 
"Users interviewed by Energy User News applauded the switch to increased use of nuclear power, even though the reactors construction costs will mean higher electricity rates now.

"Most users contacted by EUN said they would not mind paying more per kwh now as long as they would be paying a relatively cheaper kwh cost in the future, and as long as they could be assured that the uranium would be in plentiful supply.

"The rates the company will be requesting to help defer the costs of building the nuclear plants aren't that much different than if we were building three coal plants instead', the Commonwealth Edison spokesman said, noting that the costs of building a coal plant are about 1.2 billion, compared to about 1.4 billion for a nuclear plant.

"'We estimated that if we had used low-sulphur coal to supply the 41 percent of the power generated through our existing nuclear plants, electricity rates for commercial and industrial users could have been at least 17 percent higher last year. If we had used oil to supply the same amount, rates could have been as much as 45 percent higher,' he said.

"Edison is currently building three nuclear stations that according to recent estimates will cost the company close to 7.5 billion dollars by the time the last unit goes on-line in 1986, the spokesman said. 
"When the first unit of the LaSalle County nuclear station goes on-line next April, 53 percent of the power Edison generates will be through nuclear plants, the spokesman said, adding that the percentage will increase as the rest of the units begin operating." 
Atomic Industrial Forum

March/April1/, page 12의 (Recent Foreign Orders of Nuclear Plants)

March/April, page 63 (LWR Fuel Cycle Economics)

Capacity, Nuclea̧r, Electric Generating

Each Issue $\frac{3}{1}$ page 1, (Status of U.S. Nuclear Electric Generating Capacity)

January/February, page 3 (Proposed Changes to U.S. Generating Capacity, 1980-1989)

January/February, page 61 (U.S. and Foreign Nuclear Power Plant Performance in 1980)

March/April, page 3 (Decline in U.S. Utility Commitment to Nuclear Power)

May/June, page 3 (New Generating Capacity)

July-September, page 9 (U.S. Electric Power Supply and Demand, 1981-1990)

July-September, page 18 (NERC's Electric Power Projections)

July-September, page 59 (Capacity Factors, Unit Availability and Forced Outage Rate)

October-December, page 18 (NERC's Electric Power Projection for 1981-1990)

October-December, page 27 (Electrical World's Forecast of Peakload and Capita1 Expenditures)

Coa1

October-December, page 46 (NCA Revised Coal Forecast for 1981)

Construction

October-December, page 7 (Revitalizing Nuclear Power Plant Design and Construction: Lessons Learned by TVA)

Costs

Plant Capital and Production Costs (Fue1, Operation and Maintenance)

March/April, page 52 (Analysis of Utility Reports on Nuclear Power Plant Capital Costs (Form 1)

May/June, page 36 (Electrical World's 1981 Annual Statistical

Report on Capital Expenditures)

October-December, page 48 (Analysis of Utility Reports on

Nuclear Power Plant Capital Costs (Form 254))

Fue1 Costs

March/April, page 63 (LWR Fuel Cycle Economics)

I/ A11 months refer to 1981 .

2/ Pages always refer to the first page of the article, although the pertinent information may appear later in the article.

3/ Each issue refers to the following: January/February, March/April, May/June, July-September and October-December. 
Total Generating Costs

January/February, page 57 (The Cost of Replacing Nuclear Power)

May/June, page 22 (Comparison of Utility Nuclear and Coal-Fired Power Plant Generation Costs in 1980)

July-September, page 51 (TVA Study: Cost Comparison of Nuclear Versus Coal-Fired Power)

October-December, page 58 (Nuclear Versus Fossil Cost Post TMI)

Department of Energy (DOE)

January/February, page 3 (Proposed Changes to U.S. Generating

Capacity, 1980-1989)

July-September, page 30 (Survey of United States Uranium Marketing Activity)

October-December, page 40 (Spent Fuel and Radioactive Waste)

Electric Generating Units (Nuclear and Fossil)

January/February, page 61 (U.S. and Foreign Nuclear Power Plant

Performance in 1980)

March/April, page 3 (Decline in U.S. Utility Commitment to Nuclear

Power)

March/April, page 12 (Recent Foreign Orders of Nuclear Power Plants)

May/June, page 3 (New Generating Capacity)

October-December, page 4 (Summary of Licensed Operating Reactors)

Electricity, Sales and Revenues

Each Issue, Section II.A (U.S. Electric Utility Statistics)

Electric Power Research Institute

May/June, page 7 (A Program for Improving Next-Generation Light Water Reactors)

Energy, Electric

Each Issue, Section II.A (U.S. Electric Utility Statistics)

Fuel

Fossil - Also see "Coal" and "Oil"

Nuclear - Also see "Uranium"

January/February, page 57 (The Cost of Replacing Nuclear Power)

March/April, page 24 (Foreign Uranium in the U.S. Market)

October-December, page 40 (Spent Fuel and Radioactive Waste) 
Health and Safety

January/February, page 34 (Comparative Risks of Electricity Production Systems)

January/February, page 50 (ACRS Statement on the Safety and Feasibility of Nuclear Waste Storage and Disposal)

Light Water Reactor (LWR)

May/June, page 7 (A Program for Improving Next-Generation Light Water Reactors)

Load Growth

Ju1y-September, page 25 (Peak Load Growth at 2.7 Percent Per Year to 2000)

October-December, page 27 (Electrical World's Forecast of Peakload and Capital Expenditures)

National Coal Association

October-December, page 41 (NCA Revised Coal Forecast for 1981)

National Electric Reliability Council (NERC)

March/April, page 85 (NERC Report on Generating Equipment Availability

for Period 1969-1978)

July-September, page 18 (NERC's Electric Power Projections)

October-December, page 14 (NERC's Electric Power Projections for 1981-1990)

October-December, page 67 (NERC - Ten Year Review on Equipment Availability and Component Cause Code Report)

Nuclear Regulatory Commission

October-December, page \& (Summary of Licensed Operating Reactors)

Nuclear Waste

January/February, page 50 (ACRS Statement on the Safety and Feasibility of Nuclear Waste Storage and Disposal)

March/April, page 38 (U.S. Commercial Nuclear Waste and Interim Spent

Fuel Management Programs)

October-December, page 40 (Spent Fuel and Radioactive Waste)

Operation

U.S. Nuclear Plants

March/April, page 85 (NERC Report on Generating Equipment Availability for Period 1969-1978)

July-September, page 59 (Capacity Factors, Unit Availability and Forced Outage Rate)

July-September, page 62 (A Survey of Occupational Employment in the Nuclear Power Industry)

October-December, page 5? (NERC - Ten Year Review on Equipment Availability and Component Cause Code Report) 
Orders

Each Issue, Appendix

March/April, page 12 (Recent Foreign Orders of Nuclear Power Plants)

Performance

January/February, page 61 (U.S. and Foreign Nuclear Power Performance)

March/April, page 98 (NRC Data on 1980 Nuclear Power Plant Performance)

Policy and Plans

March/April, page 3 (Decline in U.S. Utility Commitment to Nuclear Power)

March/April, page 38 (U.S. Commercial Nuclear Waste and Interim Spent Fuel Management Programs)

Risk Assessment

January/February, page 34 (Comparative Risks of Electricity Production Systems)

Savings, Fuel and Cost with Nuclear Power

January/February, page 57 (The Cost of Replacing Nuclear Power)

Schedules, Delays

March/April, page 16 (Schedule Slippage in U.S. Nuclear Power Plant Projects - 1975 through 1980)

July-September, page 4 (Schedule Slippage in U.S. Nuclear Power Plant Projects - 1975 through Mid-1981)

Schedules, Project Lead Times

January/February, page 25 (Generating Unit Construction Lead Times)

Tennessee Valley Authority

July-September, page 51 (TVA Study: Cost Comparison of Nuclear Versus Coal-Fired Power)

October-December, page 7 (Revitalizing Nuclear Power Plant Design and Construction: Lessons Learned by TVA)

Three Mile Island

May/June, page 45 (TMI-2 System for Containment Cleanup)

October-December, page 91 (TMI-2 Update on Decontamination Process)

Uranium

March/April, page 24 (Foreign Uranium in the U.S. Market)

July-September, page 30 (Survey of United States Uranium

Marketing Activity) 
U.S. Nuclear Power Plants. Status of Each Issue (Section I.A)

Utilities

March/April, page 3 (Decline of U.S. Utility Commitment to Nuclear Power)

May/June, page 3 (New Generating Capacity)

July-September, page 42 (Financial Health of the Electric Utility Sector)

Briefs

Each Issue, Section IV

Statistics

Each Issue, Section II.A

Waste Management

March/April, page 38 (U.S. Commercial Nuclear Waste and Interim Spent Fuel Management Programs)

October-December, page 40 (Spent Fuel and Radioactive Waste) 